\title{
The Federal Energy Technology Center Annual Site Environmental Report for Calendar Year 1998
}

\section{October 1999}

U.S. Department of Energy Federal Energy Technology Center

Pittsburgh, Pennsylvania

Morgantown, West Virginia

FETC's Customer Service Line: (800) 553-7681

FETC's Homepage: http://www.fetc.doe.gov 


\section{DISCLAIMER}

Reference herein to any specific commercial product, process, or service by trade name, trademark, manufacturer, or otherwise does not necessarily constitute or imply its endorsement, recommendation, or favoring by the United State Government or any agency thereof. The views and opinions of authors expressed herein do not necessarily state or reflect those of the United States Government or any agency thereof.

Available to DOE employees and contractors from the Office of Scientific and Technical Information, P.O. Box 62, 175 Oak Ridge Turnpike, Oak Ridge, TN 37831; prices are available by phone: (423) 576-8401; fax: (423) 576-5725; or e-mail: reports@adonis.osti.gov.

Available to the public from the National Technical Information Service, U.S. Department of Commerce, 5285 Port Royal Road, Springfield, VA 22161; phone orders accepted at (703) 487-4650. 


\section{TABLE OF CONTENTS}

Page

LIST OF TABLES $\ldots \ldots \ldots \ldots \ldots \ldots \ldots \ldots \ldots \ldots \ldots \ldots \ldots \ldots$

PREFACE $\ldots \ldots \ldots \ldots \ldots \ldots \ldots \ldots \ldots \ldots \ldots \ldots \ldots \ldots \ldots \ldots$ vii

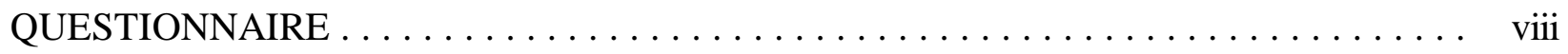

EXECUTIVE SUMMARY $\ldots \ldots \ldots \ldots \ldots \ldots \ldots \ldots \ldots \ldots \ldots \ldots \ldots \ldots$

$1.0 \quad$ INTRODUCTION $\ldots \ldots \ldots \ldots \ldots \ldots \ldots \ldots \ldots \ldots \ldots \ldots \ldots \ldots \ldots$

2.0 COMPLIANCE SUMMARY $\ldots \ldots \ldots \ldots \ldots \ldots \ldots \ldots \ldots \ldots \ldots \ldots \ldots$

2.1 Comprehensive Environmental Response, Compensation, and Liability Act

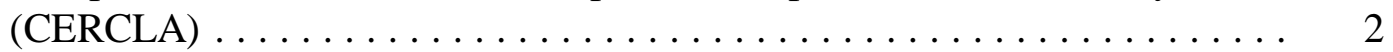

2.2 Superfund Amendments and Reauthorization Act (SARA) $\ldots \ldots \ldots \ldots \ldots$

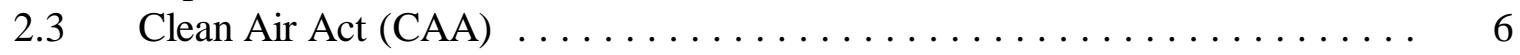

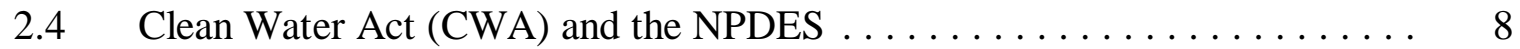

2.5 Resource Conservation and Recovery Act (RCRA) . . . . . . . . . . . . 11

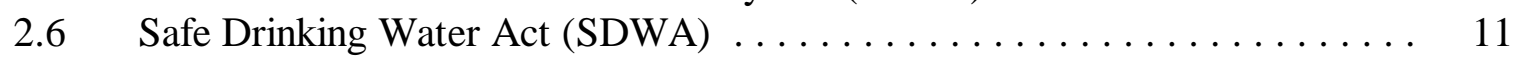

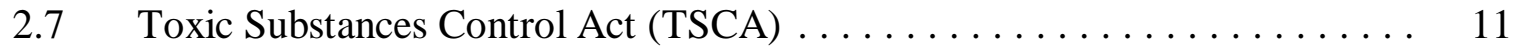

$2.8 \quad$ Federal Insecticide, Fungicide, and Rodenticide Act (FIFRA) . . . . . . . . . 12

2.9 National Environmental Policy Act (NEPA) . . . . . . . . . . . . . 12

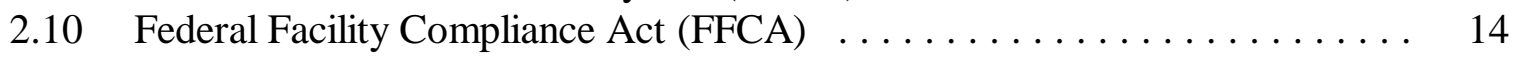

3.0 OTHER ENVIRONMENTAL ISSUES AND ACTIONS $\ldots \ldots \ldots \ldots \ldots \ldots \ldots$

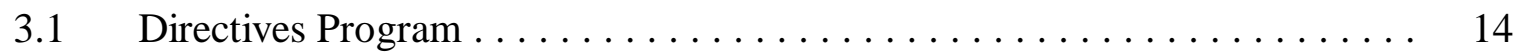

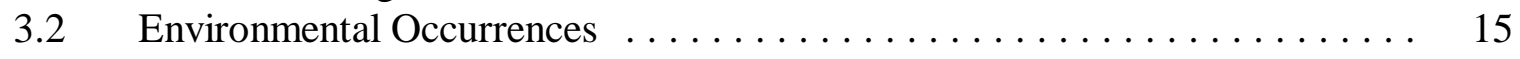

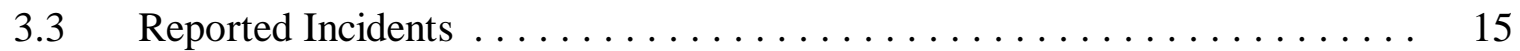

4.0 ENVIRONMENTAL MANAGEMENT INFORMATION $\ldots \ldots \ldots \ldots \ldots \ldots$

$4.1 \quad$ Environmental Monitoring and Surveillance $\ldots \ldots \ldots \ldots \ldots \ldots \ldots$

4.2 Integrated Management Activities . . . . . . . . . . . . . . 16

5.0 ENVIRONMENTAL RADIOLOGICAL PROGRAM INFORMATION $\ldots \ldots \ldots$

6.0 ENVIRONMENTAL NON-RADIOLOGICAL PROGRAM INFORMATION . . . 19

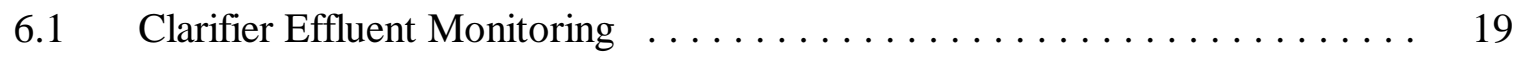

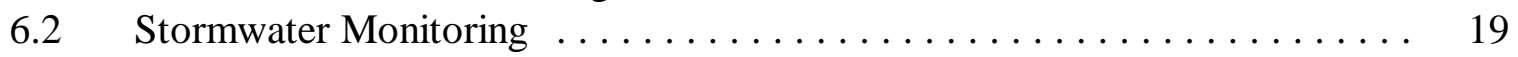

7.0 GROUNDWATER MONITORING AND PROTECTION $\ldots \ldots \ldots \ldots \ldots$

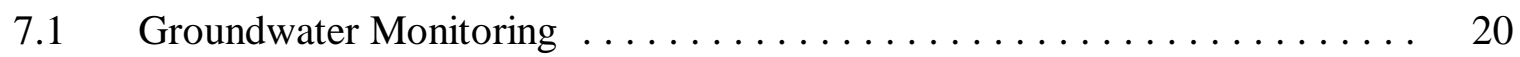

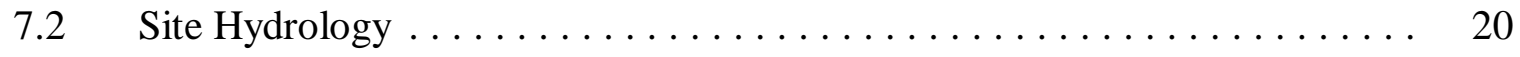


ACRONYMS AND ABBREVIATIONS .

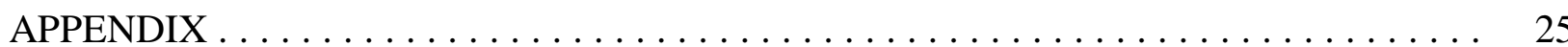




\section{LIST OF TABLES}

$\underline{\text { Table }}$

$\underline{\text { Page }}$

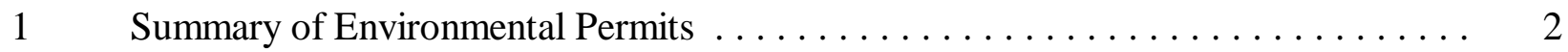

2 Emergency Planning and Community Right-to-Know Act Reporting $\ldots \ldots \ldots$

3 Sara Title III, Tier II Chemical Inventory Reporting List $\ldots \ldots \ldots \ldots \ldots \ldots$

$4 \quad$ Estimated Air Emissions for $1998 \ldots \ldots \ldots \ldots \ldots \ldots \ldots \ldots \ldots \ldots$

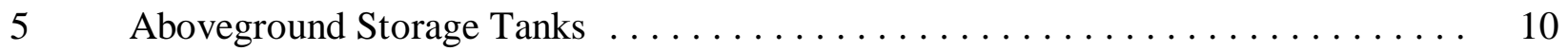

$6 \quad$ FETC Radioactive Materials Inventory (February 1998) . . . . . . . . . . . . . 17

7 FETC-PGH 1998 National Pollutant Discharge Elimination System

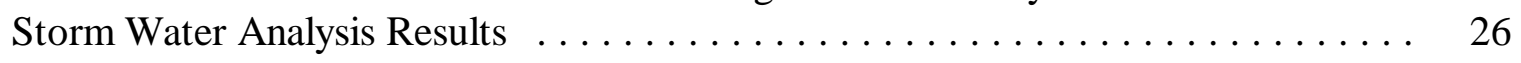

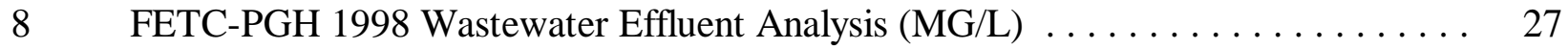

9 FETC-PGH 1998 Groundwater Detection Monitoring Program

Main Plateau - Contamination Indicator Constituents . . . . . . . . . . . . . . . . . 29

10 FETC-PGH 1998 Groundwater Detection Monitoring Program

Valley Fill - Contamination Indicator Constituents . . . . . . . . . . . . . . 32

11 FETC-PGH 1998 Groundwater Detection Monitoring Program

Main Plateau - Groundwater Characteristics Constituents ..... . . . . . . . 35

12 FETC-PGH 1998 Groundwater Detection Monitoring Program

Valley Fill - Groundwater Characteristics Constituents . . . . . . . . . . . . 38

13 FETC-PGH 1998 Groundwater Detection Monitoring Program

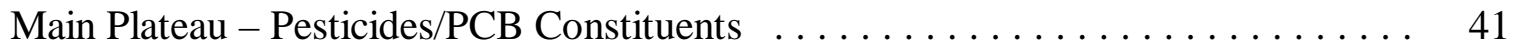

14 FETC-PGH 1998 Groundwater Detection Monitoring Program

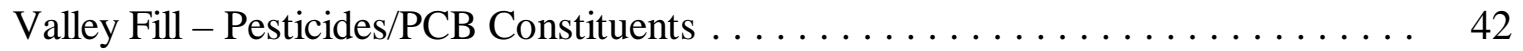

15 FETC-PGH 1998 Groundwater Detection Monitoring Program

Main Plateau - Semivolatile Organic Compounds Constituents . . . . . . . . . . 43

16 FETC-PGH 1998 Groundwater Detection Monitoring Program

Valley Fill - Semivolatile Organic Compounds Constituents . . . . . . . . . . . . . 45 
17 FETC-PGH 1998 Groundwater Detection Monitoring Program

Valley Fill - TPH Constituents $\ldots \ldots \ldots \ldots \ldots \ldots \ldots \ldots \ldots \ldots \ldots \ldots \ldots \ldots \ldots \ldots$

18 FETC-PGH 1998 Groundwater Detection Monitoring Program

Main Plateau - Volatile Organic Compounds Constituents .............. 48

19 FETC-PGH 1998 Groundwater Detection Monitoring Program

Valley Fill - Volatile Organic Compounds Constituents $\ldots \ldots \ldots \ldots \ldots \ldots . \quad 50$

20 FETC-MGN Groundwater Data for "Morgantown Aquifer"

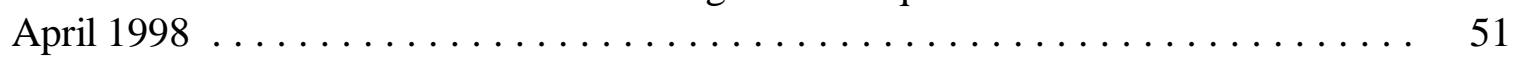

21 FETC-MGN Groundwater Data for "A Aquifer"

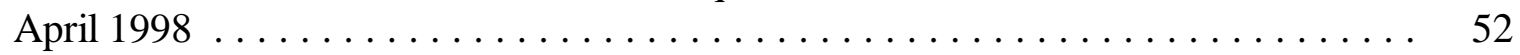

22 FETC-MGN Groundwater Data for "B-C Aquifer"

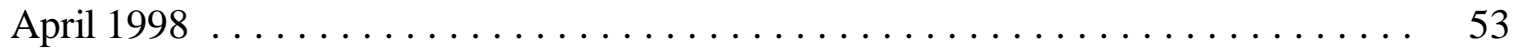

23 FETC-MGN Groundwater Data for "Morgantown Aquifer" August 1998 ....................................... 54

24 FETC-MGN Groundwater Data for "A Aquifer"

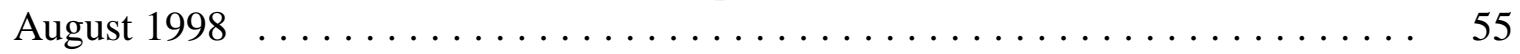

25 FETC-MGN Groundwater Data for "B-C Aquifer"

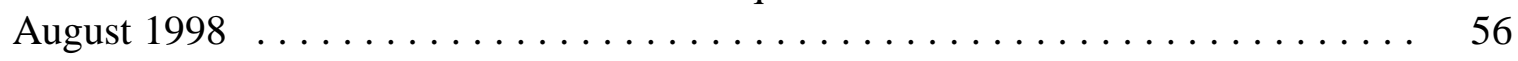




\section{PREFACE}

This Site Environmental Report was prepared by the Environment, Safety, and Health Division at the Federal Energy Technology Center (FETC) for the U.S. Department of Energy. The purpose of this report is to inform the public and Department of Energy stakeholders of the environmental conditions at the FETC sites in Morgantown, West Virginia, and Pittsburgh, Pennsylvania. This report contains the most accurate information that could be collected during the period between January 1, 1998, through December 31, 1998. As stated in DOE Orders 5400.1 and 231.1, the purpose of the report is to:

- $\quad$ Summarize environmental data to characterize site environmental management performance.

- $\quad$ Confirm compliance with environmental standards and requirements.

- $\quad$ Highlight significant programs and efforts.

A reader questionnaire/comment form has been included on the following page to provide an opportunity for public input on current and future site environmental reports.

\section{Office of Fossil Energy \\ Commitment to Environment, Safety and Health}

Fossil Energy is committed to conducting our mission to achieve the greatest benefit for all our stakeholders, including our employees and the public, while actively adhering to the highest standards for environment, safety, and health. Fossil Energy will continuously improve our practices through effective integration of environment, safety, and health into all facets of work planning and execution. Fossil Energy will make consistent, measurable progress in implementing this commitment throughout our operations while striving for zero injuries, incidents, and environmental releases. 


\section{QUESTIONNAIRE \\ FEDERAL ENERGY TECHNOLOGY CENTER \\ 1998 SITE ENVIRONMENTAL REPORT}

Please answer the following questions and return to:

Elias George

Federal Energy Technology Center - Pittsburgh

P.O. Box 10940

Pittsburgh, PA 15236

1) Was the 1998 Site Environmental Report easy to read and understand? If not, please provide a brief explanation.

2) Was the information contained in the report useful? Please provide a brief explanation.

3) Do you feel the report contained all of the information that you would be interested in? If not, please provide a brief explanation.

4) Do you have any comments or suggestions on how the current and future reports can be improved?

5) Other comments or suggestions? 


\section{EXECUTIVE SUMMARY}

No environmental problems of significance were identified during 1998. The Federal Energy Technology (FETC) sites in Morgantown and Pittsburgh currently maintain complete monitoring programs for groundwater, stormwater discharge, laboratory wastewater discharge, and meteorological data. In addition, an annual air emissions inventory is prepared for each site.

A comprehensive Directives Program aimed at environmental, safety, and health requirements and risks was initiated in 1997, continued throughout 1998, and will be completed in late 1999 or early 2000. The Directives Program will be used to identify and implement standards that will adequately protect workers, the public, and the environment. This program started with a careful and thorough analysis of risks confronting workers and the communities surrounding FETC sites. Following this analysis, requirements and best management practices were evaluated to determine how the multitude of requirements could best be used to advance the mission of FETC. Teams of subject-matter experts analyzed the work assigned to determine potential hazards and identify ways to remove or control those hazards.

The primary objective of the program is to identify or develop a set of standards that, when implemented, provides reasonable assurance that the health and safety of the workers, public, and the environment will be protected during the performance of the work. In conjunction with the Directives Program, the use of the voluntary environmental management system, ISO 14000, was evaluated. This includes the only environmental management standard to which an entity can be registered. Plans are to consider the specifications and guidance from this standard in the identification of an effective environmental management system for the merged FETC sites.

A performance measurement system continued to be maintained during 1998 to assist in evaluating how effectively activities at FETC meet mission-critical goals and how well missions and strategies are connected in the DOE strategic plan. This system also provides data to assist in gauging performance against the DOE critical success factors, that is, performance against technical objectives. Various environmental milestones can be tracked to completion, thus giving the FETC measures by which to gauge the sites' goals of remaining in regulatory compliance and achieving best-in-class environmental performance. 


\subsection{INTRODUCTION}

The Federal Energy Technology Center (FETC) was established in December 1996 as the result of a merger of the Morgantown Energy Technology Center and the Pittsburgh Energy Technology Center. FETC is a matrix organization, where employees located at the Morgantown and Pittsburgh sites operate organizationally under the same management team.

This Site Environmental Report is the third merged environmental analysis performed on these two sites. We have dedicated ourselves to achieving a seamless environmental program; however, with the sites located more than sixty (60) miles apart and in different states (West Virginia and Pennsylvania), and with different regulatory agencies involved, various reporting and monitoring issues must be discussed separately in this report.

\subsection{COMPLIANCE SUMMARY}

During 1998, FETC conducted numerous activities to comply with federal, state, and local regulations, as well as internal requirements and Department of Energy (DOE) orders. This report provides information about activities and data related to compliance. This document does not address regulations where no action was required or there is no new information to report.

Programs in air, water, soil, waste, and community "Right to Know," along with other environmental issues, were conducted. All hazardous wastes were managed and removed from the merged sites in accordance with allowable accumulation times specified in the Resource Conservation and Recovery Act (RCRA) regulations. A summary of permits related to environmental activities conducted in 1998 is presented in Table 1 on the following page. 


\section{Table 1}

Summary of Environmental Permits

\begin{tabular}{|c|c|c|}
\hline Permit Type & Permit Number & Status \\
\hline Air & $\begin{array}{l}\text { MGN: } \\
\text { R13-1768 } \\
0610064 \\
\text { PGH: } \\
7032056-000-00500 \\
7032056-000-00501 \\
7032056-000-0800\end{array}$ & $\begin{array}{l}\text { MGN: } \\
\text { West Virginia Office of Air Quality issues the permits. Right to } \\
\text { Construct and Right to Operate SynGas Generator/PDU. } \\
\text { PGH: } \\
\text { Allegheny County issues the permits. Natural gas boilers used } \\
\text { for heating buildings and one gas-coal fired research unit. }\end{array}$ \\
\hline $\begin{array}{l}\text { Water } \\
\text { (NPDES) }\end{array}$ & $\begin{array}{l}\text { MGN: } \\
\text { MUB Permit No. } 012 \\
\text { WV0111457 } \\
\text { PGH: } \\
\text { Part I - PA0025844 } \\
\text { Part II - } 0297201\end{array}$ & $\begin{array}{l}\text { MGN: } \\
\text { All monitored parameters were within permit limitations during } \\
1998 . \\
\text { PGH: } \\
\text { Part I for a National Pollutant Discharge Elimination System } \\
\text { (NPDES) stormwater discharge permit issued by PaDEP. } \\
\text { Part II for an industrial settling weir owned by NIOSH. All } \\
\text { monitored parameters were within permit limitations during } \\
1998 .\end{array}$ \\
\hline Storage Tanks & $\begin{array}{l}\text { PGH: } \\
02-81183008 \mathrm{~A} \\
02-81183009 \mathrm{~A} \\
02-81183010 \mathrm{~A} \\
02-81183012 \mathrm{~A}\end{array}$ & Aboveground storage tank permits issued by PaDEP. \\
\hline Asbestos & $\begin{array}{l}\text { PGH: } \\
\text { PAA98-0512 } \\
\text { PAA98-0510 } \\
\text { PAA98-0511 } \\
\text { PAA98-0491 } \\
\text { PAA98-0438 } \\
\text { PAA98-0439 } \\
\text { PAA98-0556 }\end{array}$ & $\begin{array}{l}\text { Asbestos Abatement Permits Issued through the Allegheny } \\
\text { County Pennsylvania, Health Department, Air Pollution Division. }\end{array}$ \\
\hline
\end{tabular}

\subsection{Comprehensive Environmental Response, Compensation, and Liability Act (CERCLA)}

Sites at Morgantown and Pittsburgh had no CERCLA-related activity during 1998; however, the following sections describe CERCLA-related activity at remote sites in other areas of the United States that remain the total or partial responsibility of the Department of Energy. These areas continue to be monitored for appropriate environmental responses. 


\section{Rock Springs, Wyoming}

In Rock Springs, Wyoming, the Rock Springs Oil Shale Retort site consists of 13 locations where in-situ shale fracturing and retorting research was conducted. As a result of research activities, groundwater was contaminated with organic compounds and must be cleaned up to standards set forth in the Wyoming Environmental Quality Act. Although the site was not listed on the Federal Agency Hazardous Waste Compliance Docket, FETC proactively tasked the Tennessee Valley Authority (TVA) to conduct a Preliminary Assessment (PA) of the site in 1993, in accordance with CERCLA, to determine if the site should be placed on the National Priority List (NPL). After reviewing the PA, which resulted in a score of 2, EPA Region VIII classified the site as Site Evaluation Accomplished (SEA) under the Federal Superfund Program and notified FETC that the site would not be evaluated further for inclusion on the NPL. As a result, the DOE must satisfy State of Wyoming requirements as defined by the Wyoming Environmental Quality Act.

During 1998, the U.S. Army Corps of Engineers and contractors continued characterization efforts at the Rock Springs site with primary emphasis on groundwater monitoring and removal of contaminated groundwater from Site 9 through a 180-day pumping pilot demonstration. The pilot demonstration's purpose was to assess the value of removing groundwater from the Tipton formation over a long period of time to determine if contaminant levels could be sufficiently reduced through this method and be used as a preferred remedial alternative for site cleanup. Although contaminant levels were reduced slightly, the pilot demonstration results indicated the pumping method was ineffective in removing contaminants from the groundwater at Site 9. However, additional information on site geology, hydrology, fracture patterns, and preferential flow paths was collected. The Wyoming Department of Environmental Quality (WDEQ) requested expanded investigations at Sites 4, 6, 7, and 12, with exploratory wells drilled near the center of each of the retort areas. Groundwater samples were collected and analyzed to determine the level of contamination present at each of the retort sites.

Pilot demonstrations were designed and constructed at Sites 4/7, 9, and 12. Air injection and bioremediation actions were undertaken at each of the three sites, with a more aggressive air sparge system being utilized at Site 4/7, minimal aeration/water extraction and injection with nutrient injection demonstrated at Site 9, and minimal air injection/water extraction and injection at Site 12. The demonstrations were conducted through August 1999, at which time an evaluation was conducted to determine the preferred remedial alternative. The Wyoming Department of Environmental Quality (WDEQ) concurred with the pilot demonstration actions and will be involved in determining the preferred remedial alternative for site cleanup.

\section{Gillette, Wyoming}

In Gillette, Wyoming, the Hoe Creek Underground Coal Gasification site consists of three locations where coal was gasified in situ. As a result of the field tests, coal tars remain underground in two coal seams and in the channel sand overburden. Water flowing through the coal and the channel sand is leaching organic compounds from source materials into the groundwater, and contaminant levels have exceeded state regulatory limits. Annual pump and treat operations have been conducted during the summer months as an interim measure to minimize any contaminated groundwater movement out of the boundaries of the R\&D permit area 
onto private lands. Contaminated groundwater has migrated onto one private landowner's property located to the east of the permit area. During 1994 through 1996, approximately $14,127,000$ liters $(3,774,000$ gallons) of water were pumped, treated by routing through activated carbon filters, and applied to the ground surface, via a spray system through atomizing nozzles, in an attempt to contain the contamination on the permit area.

The Hoe Creek site was listed on the Federal Agency Hazardous Waste Compliance Docket on June 1, 1991. A preliminary assessment of the Hoe Creek site was conducted in 1993, in accordance with CERCLA requirements, to determine if the site should be placed on the NPL. After reviewing the preliminary assessment with a score of 14, the EPA Region VIII Office classified the site as SEA under the Federal Superfund Program and notified FETC that the site would not be evaluated further for inclusion on the NPL. As a result, requirements imposed by the Wyoming Environmental Quality Act must be met.

On February 7, 1998, the air sparge/bioremediation system was completed at the Hoe Creek II area of the Hoe Creek site. Air is being injected into the Felix I and II aquifers through 64 wells that were completed during the construction phase. Two 75 horsepower electric compressors supply the air necessary for delivery to the groundwater system for air sparging actions. Groundwater samples are scheduled to be extracted three times per year, and will occur at 111 day intervals (Day 111, 222, 333). The balance of days per year are consumed by periods of shutdown prior to sampling, and start-up time periods before resumption of air sparging activities.

Construction of the Hoe Creek III air sparge/bioremediation system was initiated during October, 1998. Fifty air sparge wells were completed in the Felix I and II aquifers, with six wells installed as a sparge curtain down gradient form the well field. Two 100 horsepower electric compressors supply the air necessary for delivery to the groundwater system for air sparging actions. Groundwater samples are scheduled to occur three times per year, and will occur at 111 day intervals. It is anticipated the air sparge/bioremediation systems at Hoe Creek II and III will continue operation for up to 5 years. Groundwater remediation must continue until water quality is returned to baseline conditions or to class of use through Best Practicable Technology, as required by the WDEQ.

\section{Hanna, Wyoming}

The Hanna Underground Coal Gasification site's experiments were conducted in the 1970's, and the WDEQ has approved groundwater restoration for the site. Revegetation of the site surface remains to be accomplished prior to the WDEQ giving a final release and allowing termination of the R\&D permit area. A revegetation evaluation, conducted on reclaimed disturbed areas on the permit area in 1998, indicated vegetation cover density, productivity, and species diversity are close to satisfying the WDEQ requirements for final release. Final bond release and termination of the Research and Development License are expected in Fiscal Year 2000.

\subsection{Superfund Amendment and Reauthorization Act (SARA)}

Title III of the Superfund Amendment and Reauthorization Act (SARA) of 1986 is known as the Emergency Planning and Community Right-to-Know Act (EPCRA). This Act requires owners or 
operators of facilities that have certain hazardous chemicals on site to provide information on the release, storage, and use of those chemicals to organizations responsible for emergency response planning. Executive Order 12856, signed by President Clinton on August 3, 1993, directs all federal agencies to comply with the requirements of EPCRA, including SARA 313 Toxic Release Inventory Program.

All EPCRA reporting requirements pertinent to FETC have been met at both the Morgantown and Pittsburgh sites. Table 2 identifies those requirements for which FETC has filed or will be required to report in the event of an occurrence.

\section{TABLE 2}

Emergency Planning and Community Right-to-Know Act Reporting

\begin{tabular}{|l|c|c|c|}
\hline \multicolumn{1}{|c|}{ Reporting Requirements } & Yes & No & $\begin{array}{c}\text { Not } \\
\text { Required }\end{array}$ \\
\hline EPCRA 302-303: Planning Notification & $\begin{array}{c}\mathrm{X} \\
(\mathrm{PGH})\end{array}$ & & $\begin{array}{c}\mathrm{X} \\
(\mathrm{MGN})\end{array}$ \\
\hline EPCRA 304: EHS Release Notification & $\mathrm{X}$ & & \\
\hline EPCRA 311-312: MSDS/Chemical Inventory & $\mathrm{X}$ & & \\
\hline EPCRA 313: TRI Reporting & & & $\mathrm{X}$ \\
\hline
\end{tabular}

Note: Due to differences in the hazards at each site, the EPCRA reporting requirements for Section 302 and 303 are not the same at the two sites.

Section 302 of EPCRA requires the owner or operator of any facility at which an extremely hazardous substance is present in amounts equal to or greater than specified threshold planning quantities to notify the SERC that the facility is subject to the emergency planning requirements. Section 303 of EPCRA requires the facility to designate a facility representative to participate in local emergency planning as a facility emergency response coordinator. The Pittsburgh site has previously notified the emergency response commission under Sections 302 and 303 and periodically updates emergency contact information with revised Section 311/312 submittals.

Both FETC sites fall under the requirements of EPCRA 304, and in the event of a release are subject to the emergency notification requirements under Section 103(a) of the CERCLA of 1980. No releases requiring emergency notification occurred during this 1998 reporting period.

SARA Title III requirements call for reporting of "all hazardous chemicals present at the facility during the preceding calendar year in amounts equal to or greater than 10,000 pounds or that are extremely hazardous substances present at the facility in an amount greater than or equal to 500 pounds (or 55 gallons), or the Threshold Planning Quantity (TPQ), whichever is less." Table 3 lists those chemicals reported by FETC for 1998. Section 312 directs the owner or operator to prepare or have available an MSDS for a hazardous chemical and submit an emergency and hazardous chemical inventory form by March 1 of each year if the amount of the chemical equals or exceeds the TPQ. FETC maintains an active inventory of all hazardous materials on site along with the Material Safety Data Sheets (MSDS) for each of these substances. 
The state and local emergency planning committees and local fire departments have been advised of all materials, quantities, and their location on the FETC sites. MSDS information on all materials has been made available.

Under the Pennsylvania Hazardous Material Emergency Planning and Response Act (Act 165) submission of the Tier II Hazardous Chemical Inventory Form meets Section 312 requirements. Section 313 of EPCRA, the Toxic Release Inventory (TRI) Reporting Program, requires the owner or operator of certain facilities that manufacture, process or otherwise use listed toxic chemicals above threshold amounts to submit to EPA and designated state officials annual toxic chemical release inventory forms (Form R) for such toxic chemicals released into the environment. FETC did not exceed the threshold amounts for the listed toxic chemicals and thus was not required to submit a Form $\mathrm{R}$.

TABLE 3

SARA Title III, Tier II Chemical Inventory Reporting List

\begin{tabular}{|c|c|c|l|l|}
\hline $\begin{array}{c}\text { Chemical Name } \\
\text { (Ib) }\end{array}$ & $\begin{array}{c}\text { Quantity } \\
\text { (Ib) }\end{array}$ & \multicolumn{1}{|c|}{$\begin{array}{c}\text { Physical } \\
\text { Hazards }\end{array}$} & Health Hazards \\
\hline $\begin{array}{c}\text { Nitrogen } \\
\text { (MGN) }\end{array}$ & $10,000+$ & & Pressure & Acute \\
\hline $\begin{array}{c}\text { Hydrogen- } \\
\text { Sulfide } \\
\text { (MGN) }\end{array}$ & & TPQ & $\begin{array}{l}\text { Fire } \\
\text { Pressure } \\
\text { Reactivity }\end{array}$ & $\begin{array}{l}\text { Immediate (Acute) } \\
\text { Delayed (Chronic) }\end{array}$ \\
\hline $\begin{array}{c}\text { Coal } \\
\text { (MGN) }\end{array}$ & $10,000+$ & Fire & Chronic \\
\hline \hline $\begin{array}{c}\text { Alumina } \\
\text { (MGN) }\end{array}$ & $10,000+$ & & Fire & $\begin{array}{l}\text { Immediate (Acute) } \\
\text { Delayed (Chronic) }\end{array}$ \\
\hline \hline $\begin{array}{c}\text { Sulfur Dioxide } \\
\text { (PGH) }\end{array}$ & 2612 & 500 & Pressure & $\begin{array}{l}\text { Immediate (Acute) } \\
\text { Delayed (Chronic) }\end{array}$ \\
\hline
\end{tabular}

\subsection{Clean Air Act (CAA)}

Air pollutant emissions are regulated under the CAA as amended (42 USC 7401 through 7642). EPA's regulations are contained in 40 CFR 50 through 87.

West Virginia regulates ambient air quality through the West Virginia Department of Environmental Protection (WVDEP); Office of Air Quality. The West Virginia Air Pollution Control Regulations are located in Title 45 - WV Code; and Series 1-7a, 10, 11, 13-15, and 17-26.

Pennsylvania regulates ambient air quality at the Pittsburgh site through the Allegheny County Health Department's Bureau of Air Quality Control in Pittsburgh, Pennsylvania. The Pennsylvania Air Pollution Control Regulations are located in 25 PA Code Chapters 123, 127, 
131, 135, and 139. The Allegheny County regulations are located in the Air Pollution Control Article XXI.

FETC does not fall under the National Emission Standards for Hazardous Air Pollutants (NESHAP) for radionuclide emissions (40 CFR 61, Subpart H) at either the Pittsburgh or the Morgantown site. Neither site reported any radionuclide dose equivalents in its 1998 annual report. Emissions at the sites do not appear to be significant as shown in Table 4. No significant increase in air emissions occurred from 1997 to 1998.

TABLE 4

Estimated Air Emissions for 1998

\begin{tabular}{|l|c|c|}
\hline \multirow{2}{*}{\multicolumn{1}{|c|}{ Pollutant }} & \multicolumn{1}{c|}{ MGN } & \multicolumn{1}{c|}{ PGH } \\
\cline { 2 - 3 } & \multicolumn{2}{|c|}{ (tons per year) } \\
\hline Nitrous Oxides $\left(\mathrm{NO}_{\mathrm{X}}\right)$ & 14.50 & 04.29 \\
\hline Sulfur Dioxide $\left(\mathrm{SO}_{2}\right)$ & 00.06 & 14.50 \\
\hline Carbon Monoxide $(\mathrm{CO})$ & 04.21 & 00.59 \\
\hline Volatile Organics $(\mathrm{VOC})$ & 00.39 & 00.55 \\
\hline Particulates & 01.23 & 01.17 \\
\hline
\end{tabular}

\section{Air Permits}

FETC held three air permits in effect during 1998 that were issued by the Allegheny County Health Department for the Pittsburgh site. One permit (number 7032056-000-00500) is for a 4,500,000 Btu/hr Cleaver Brooks Natural Gas Boiler located in Building 922. The second permit (number 7032056-000-00501) is for three RayPak Finned Coppertube Boilers, each having a $1,630,000 \mathrm{Btu} / \mathrm{hr}$ input rating, located in Building 922. Permit number 7023056-000-00800 is for the $500 \mathrm{lb} / \mathrm{hr}$ gas and coal-fired research unit located in Building 86. During 1998, the site continued to be a synthetic minor source under Title V of the Clean Air Act.

Air permits for the Pittsburgh site are obtained from the Allegheny County Health Department's Bureau of Air Quality Control in Pittsburgh, Pennsylvania. Allegheny County regulates the air program as it is outlined by EPA and the Pennsylvania Department of Environmental Protection.

As part of Article XXI and to comply with Title V of the 1990 Clean Air Act Amendments, FETC submitted an application for one new plant-wide permit. A comprehensive annual air emissions inventory was an integral part of the submittal. The site was notified that the application was accepted as being administratively complete. FETC is currently awaiting the technical review of the application.

On May 1, 1995, the Morgantown site received air permit No. R13-1768 from the West Virginia Office of Air Quality (OAQ) and constructed an Experimental Syngas Generator/Hot Gas Desulfurization Process Development Unit (PDU) at the site. FETC renewed the Certificate to Operate 
for the Syngas Generator/PDU (Certificate 061 0064) for the period of July 1, 1997, through June 30, 1998. Integrated shakedown of the syngas generator and PDU is expected to last through the first part of 2000, followed by test program operations that will be used for development of gas cleanup technologies for advanced integrated coal gasification combinedcycle power generation systems. Operating summaries required by the PDU permit are submitted quarterly. During 1998, the site continued to be a synthetic minor source under Title V of the Clean Air Act.

\section{Emission Source Inspections}

EPA requires all major air sources to be inspected annually to insure compliance with the existing site air permit. An inspection of the Pittsburgh site's air emission sources was conducted by the Allegheny County Health Department's Air Quality Program Division. Results of the inspection showed that the site was in compliance.

The site maintains three 30-foot meteorological towers that monitor temperature, relative humidity, precipitation, and wind speed. Data are collected twice per week and utilized in the site's Emergency Preparedness Program, HVAC Maintenance Program, and Air Monitoring Program.

Additionally, the site conducts a stratospheric ozone depletion program to recover and reclaim chlorofluorcarbons (CFCs) from HVAC equipment. All CFC-containing equipment has been inventoried, and measures are being evaluated to phase out these materials.

In Morgantown, site air emissions are inventoried yearly to assess whether permit conditions are being met and whether any additional permits or permit modifications are needed. Results are reported to the state as required. Emissions are either measured, estimated by EPA methods, or projected by combustion and mass balance calculations. Emissions of other pollutants including benzene, lead, hydrogen sulfide, and xylene were also inventoried in 1998, but estimated values were very small. Site emissions are low overall and consistent with the previous year's inventory.

Data from the 150-foot free-standing meteorological tower are used for reporting of stormwater information and by the Emergency Operations Center for predicting the effects of accidental and non-routine releases.

\subsection{Clean Water Act (CWA) and the NPDES}

Wastewater discharges are regulated under the Clean Water Act (33 USC 1251 et seq.) and subsequent federal regulations (40 CFR Parts 121, 122, 125, 136, 405-471). Both West Virginia and Pennsylvania are National Pollutant Discharge Elimination System (NPDES) authorized states. The West Virginia NPDES regulations are codified in Title 46-West Virginia Codes 1 and 2. The Pennsylvania NPDES regulations are codified in 25 Pennsylvania Code Chapters 16, 91-95, 97, 101, and 102.

In addition, Pittsburgh site wastewater placed into the sanitary sewer for subsequent treatment by the Pleasant Hills Authority (PHA) is regulated at the local level under the Pleasant Hills 
Industrial Sewer Use Permit Program (final implementation expected in 1999). Sanitary wastes were generated by approximately 1000 employees representing three distinct federal agencies at the Bruceton Research Center during 1998. All sanitary waste flows into the combined sanitary wastewater drainage systems that are tied-in to the Pleasant Hills, Pennsylvania, municipal sewer system/POTW with no prior treatment or monitoring occurring at the Pittsburgh site.

All treated laboratory and process wastewater flows to the nearby Pleasant Hills Municipal Sewage Treatment Plant. The site maintains an onsite Wastewater Treatment Facility where wastewater is collected and treated before discharge. Treatment consists of oil recovery, followed by flow equalization with subsequent neutralization through the addition of caustic soda or ferric chloride. Metals and particulates are removed via agglomeration in the flocculation tank coupled with solids separation in the plate separator and a filter press. The effluent to the sanitary sewer is monitored and can be recirculated if additional treatment is needed. The PHA has agreed to accept the discharge. FETC submits monthly wastewater analysis data and submits an annual Industrial Waste Survey Report to Pleasant Hills.

In 1998, FETC was notified that the PHA was in the process of implementing an Industrial Sewer Use permit program in compliance with U.S. Environmental Protection Agency Clean Water Act requirements. FETC was informed that the concentration limits presently in place on some of the contaminants in FETC's treated laboratory and process wastewater would be lowered. The PHA indicated that they would provide FETC with an opportunity to comment on the draft permit being developed. As of the end of 1998, this opportunity had not been presented.

The routine treated wastewater sampling and analysis program presently being carried out on the treated effluent from the Building 74 Wastewater Treatment Facility and the Building 141 Laboratory Waste Holding Tank will continue to be in effect. The analytical reports will continue to be submitted to the PHA's consulting engineering firm.

In a three-agency agreement with the U.S. Department of Interior (now identified as the National Institute for Occupational Safety and Health - NIOSH), and the U.S. Department of Labor Mine Safety and Health Administration, FETC jointly applied for a National Pollutant Discharge Elimination System (NPDES) permit to discharge stormwater associated with industrial activity into Lick Run in Pennsylvania. The joint NPDES permit (No. PA0025844) was issued to FETC during 1996. Monitoring at three outfalls is required. The North and South Outfalls (main outfalls to Lick Run) require quarterly discharge monitoring reports while an internal outfall maintained by NIOSH requires weekly monitoring and monthly reporting. During 1998 there were no exceedances. FETC also received a Part II permit (No. 0297201) for an industrial settling weir owned by NIOSH.

For the Morgantown site, FETC retained two (2) permits under the NPDES during 1998. One permit (MUB Permit No. 012), is issued by the MUB for the discharge of sanitary and pretreated industrial wastewater to the City of Morgantown's municipal sewer system/POTW. This permit will be renewed again in June 2000. All monitored parameters were within permit limitations during 1998. 
The other Morgantown permit issued under the NPDES was WV/NPDES Permit No. WV0111457, General Permit Registration No. WVG610042, issued by the West Virginia Department of Commerce, Labor and Environmental Resources Division of Environmental Protection for the discharge of stormwater to Burroughs Run and West Run. As stated in the WV/NPDES permit approval letter, FETC is required under the terms and conditions of this permit to:

1. Monitor and report annually to the State of West Virginia the level of oil and grease, $\mathrm{pH}$, BOD, COD, nitrate, nitrite, and TSS of stormwater from outfalls 002, 005, and 010. These data are to be submitted in the form of a DMR each March 9th.

2. Monitor and report monthly to the State of West Virginia the level of fecal coliform in stormwater from outfalls 002, 005, and 010. These data are to be submitted in the form of a DMR on or before the ninth of each month. These outfalls are to be monitored until the source of fecal coliform has been found and eliminated. FETC may then petition the state for relief from these monitoring and reporting requirements. Dye and smoke tests have determined that no direct cross-connections exist.

3. Maintain a Stormwater Pollution Prevention Plan. This plan is to be retained on site and made available for review by the state at their request.

Table 5 shows the status of aboveground storage tanks at both Pittsburgh and Morgantown.

TABLE 5

Aboveground Storage Tanks

\begin{tabular}{|c|c|c|c|c|}
\hline Location & Description & $\begin{array}{c}\text { Capacity } \\
\text { (U.S. Gallons) }\end{array}$ & $\begin{array}{l}\text { Active or } \\
\text { Inactive }\end{array}$ & Comments \\
\hline FETC-PGH & Waste Oil Holding Tank & 950 & Inactive & $\begin{array}{l}\text { Taken out of service in } \\
1992 .\end{array}$ \\
\hline FETC-PGH & Caustic Soda Tank & 1500 & Active & \\
\hline FETC-PGH & Ferric Chloride Tank & 1500 & Active & \\
\hline FETC-PGH & Heating Oil Tank & 2200 & Inactive & $\begin{array}{l}\text { Taken out of service in } \\
1990 .\end{array}$ \\
\hline $\begin{array}{l}\text { FETC-MGN } \\
\text { Outside B13 }\end{array}$ & $\begin{array}{l}\text { Diesel Fuel Storage } \\
\text { (Double Tank) }\end{array}$ & 50 & Active & $\begin{array}{l}\text { Used for research } \\
\text { equipment. }\end{array}$ \\
\hline $\begin{array}{l}\text { FETC-MGN } \\
\text { Outside B29 }\end{array}$ & $\begin{array}{l}\text { Diesel Fuel Storage } \\
\text { (Double Tank, Bermed) }\end{array}$ & 250 & Active & Vehicle fuel. \\
\hline $\begin{array}{l}\text { FETC-MGN } \\
\text { Outside B29 }\end{array}$ & $\begin{array}{l}\text { Gasoline Fuel Storage } \\
\text { (Double Tank, Bermed) }\end{array}$ & 500 & Active & Vehicle fuel. \\
\hline $\begin{array}{l}\text { FETC-MGN } \\
\text { Outside B34 }\end{array}$ & $\begin{array}{l}\text { Diesel Fuel Storage } \\
\text { (Double tank) }\end{array}$ & 50 & Active & $\begin{array}{l}\text { Emergency generator } \\
\text { fuel. }\end{array}$ \\
\hline $\begin{array}{l}\text { FETC-MGN } \\
\text { Outside Navy } \\
\text { Facility }\end{array}$ & $\begin{array}{l}\text { Diesel Fuel Storage } \\
\text { (Double Tank) }\end{array}$ & 500 & Active & $\begin{array}{l}\text { Emergency generator } \\
\text { fuel. }\end{array}$ \\
\hline
\end{tabular}




\subsection{Resource Conservation and Recovery Act (RCRA)}

The Resource Conservation and Recovery Act (42 U.S. Code 6901 et seq.) provides the framework at the federal level for regulating the generation and management of solid wastes, including those designated as hazardous. EPA's hazardous waste regulations are codified in Title 40 CFR Parts 260-271. There were no external audits by Headquarters, PaDEP, or WVDMR performed during 1998.

\subsection{Safe Drinking Water Act (SDWA)}

Drinking water is codified under the SDWA (42 USC 300f through $330 \mathrm{j}$ - 11) and regulated in 40 CFR Parts 141 through 143. Since FETC does not provide treatment or storage of this water, the monitoring requirements of a public water supplier are not required; however, both sites conduct sampling and analysis programs at selected potable water locations and compare samples against the SDWA primary and secondary regulatory standards.

The Morgantown site receives its potable water supply from the city of Morgantown. SDWA standards were exceeded at isolated drinking water sources in 1997. Signs were posted to warn employees of the unacceptable water until the problem has been eliminated. Monitoring continued in 1998 and no further drinking water issues were discovered.

The Pittsburgh site receives its water supply from the Pennsylvania American Water Company. Forty-two primary and secondary drinking water contaminants were sampled at nine representative locations in 1998. All of the results of the results of the sampling were below the maximum contaminant levels, so no corrective actions were taken.

\subsection{Toxic Substances Control Act (TSCA)}

The management of polychlorinated biphenyls (PCBs), asbestos, and lead are codified in the Toxic Substances Control Act (15 USC 2601 to 2654). EPA regulations addressing PCBs and asbestos in conjunction with the TSCA are codified in 40 CFR 761 and 763, respectively. Asbestos is also regulated under the CAA (40 CFR 61, Subpart M); the OSHA (29 CFR 1910.1001, and 1926.1101); and ACHD Article XXI.

A survey of all facilities for asbestos has been conducted and abatement is being performed as funding becomes available. FETC requested and received seven (7) permits from the Allegheny County Pennsylvania Health Department for asbestos abatement activities. These permits are issued by the Air Pollution Division and are typically for a short duration (several days to a few weeks). All permits were closed upon notice from the county health department that the air space had been effectively cleared of asbestos contamination.

At the Morgantown site, various asbestos abatement activities were completed in 1998, primarily drilling holes through asbestos wall panels for new conduit or pipe runs. The largest project was the cutting of asbestos wall panels in Building 3 for new air conditioning ductwork. 
A survey of lead-based paint at the Morgantown site was completed in early 1998. A priority list was made for lead paint removal projects, based on conditions of paint and proximity to workers. Lead paint removal continued in 1998 and was performed by a licensed contractor, and the lead paint debris was disposed by the site support contractor hazardous waste personnel, who had it hauled to an approved landfill.

\subsection{Federal Insecticide, Fungicide, and Rodenticide Act (FIFRA)}

Pesticides are regulated under FIFRA (USC 136 through 136 [y]). EPA pesticide regulations are codified in 40 CFR, Parts 162, 166, and 171.

In order to minimize potential for a spill of pest control products, all work statements for pest control contractors include a stipulation that the government will not furnish on-site storage for such materials and will not provide services for disposal of excess or waste materials. The use of pesticides is limited to materials that are not classified by the EPA for restricted use. Pesticides are applied by qualified contractors using certified personnel. Pest control for buildings at the Morgantown site is performed monthly or as needed, and normally entails the spraying of interior baseboards and corners.

Pest control for the cafeteria at the Pittsburgh site is performed on a monthly basis in compliance with ACHD regulations. Pest control for buildings is limited to "banding" (dispersing crystals on grassy surrounds of buildings and foundation spraying). All indoor applications are performed on an as-needed basis. Also performed on an as-needed basis is pesticide/herbicide application for grounds maintenance purposes.

\subsection{National Environmental Policy Act (NEPA)}

The National Environmental Policy Act (NEPA - 42 U.S.C. 4321 et seq.) established federal policy for protecting environmental quality. Under this policy, Environmental Impact Statements (EIS) must be prepared to evaluate the environmental consequences of any major federal or federally funded action that might have significant impact on the quality of the human environment. A Record of Decision would be prepared to document the federal decision on a course of action subsequent to an EIS review. If the need for an EIS is not clear, or if a proposed action does not meet DOE's criteria for preparation of an EIS, an Environmental Assessment (EA) would be prepared. Subsequent to preparing an EA, either a decision to prepare an EIS would be made or a Finding of No Significant Impact (FONSI) would be issued if an EIS is determined to be unnecessary.

Certain classes of actions that do not have a significant effect on the environment, either individually or cumulatively, can be categorically excluded from more in-depth NEPA review (i.e., preparation of either an EIS or EA). DOE's NEPA implementing procedures (10 CFR 1021) identify those categories of excluded actions and the eligibility criteria for their application. 


\section{Performance}

FETC conducts NEPA reviews of proposed onsite actions and proposed offsite federal actions that are planned in cooperation with federal, state, or local governments; educational institutions; or private industry. During calendar year 1998, a total of 203 NEPA reviews resulting in the approvals of categorical exclusions were performed. All new onsite activities at the FETC sites were covered by categorical exclusions in 1998 .

During 1998, and in the final three months of calendar year 1997, Environmental Assessments were completed for two projects at three offsite locations. These EAs are noted below:

DOE/EA-1219 Hoe Creek Underground Coal Gasification Test Site Remediation (Hoe Creek, Wyoming)

DOE/EA-1224 Advanced Turbine System No-Load Demonstration project (Greenville, South Carolina; Charlotte, North Carolina)

For each of these projects, FONSIs were prepared and distributed.

During 1998, efforts continued to develop EIS reviews for the following three projects:

DOE/EIS-0284 Low Emission Boiler System Proof-of-Concept Project (Elkhart, Illinois)

DOE/EIS-0280 Clean Power from Integrated Coal/Ore Reduction (CPICOR) (Vineyard, Utah)

DOE/EIS-0282 McIntosh Unit 4 Pressurized Circulating Fluidized-Bed Demonstration Project (Lakeland, Florida)

For the two proposed actions at Lakeland (FL) and Vineyard (UT), development of project plans and environmental details continued during 1998 in advance of publication of a Notice of Intent, which would initiate the public scoping process. For the proposed action at Elkhart, the Notice of Intent and public scoping processes were previously completed; work on refining technical details for the proposed action and on preparation of a draft EIS continued.

In addition, a determination to prepare an EIS was made for the following proposed action:

DOE/EIS-0289 JEA Circulating Fluidized-Bed Combustor Project (Jacksonville, Florida)

The proposed action at Jacksonville would involve financial support under a cooperative agreement with private industry to demonstrate circulating fluidized-bed combustor technology that would repower an existing 300-megawatt steam turbine at JEA's (formerly the Jacksonville Electric Authority) Northside Generating Station. The Notice of Intent and public scoping processes were completed and preparation of a draft EIS was initiated. 


\subsection{Federal Facility Compliance Act (FFCA)}

The Federal Facility Compliance Act (FFCA) is an amendment to RCRA that was initiated as a result of states protesting the perception that federal facilities are protected from fines or penalties. The Congressional intent was to waive the sovereign immunity of federal agencies, requiring them to comply with the full range of enforcement tools available to all regulatory authorities. Under the FFCA, there is explicit authority to issue administrative compliance orders that are RCRA violations and requires EPA to conduct annual inspections of federal facilities with RCRA Part B permits.

FFCA also encourages federal facilities to seek voluntary resolution to environmental challenges. FETC sites are not currently under onsite consent agreements and are not RCRA Part B facilities. The sites do, however, conduct their environmental programs in accordance with applicable federal, state, and local regulations.

\subsection{OTHER MAJOR ENVIRONMENTAL ISSUES AND ACTIONS}

Current issues not mentioned in the previous sections of this report are covered below.

\subsection{Directives Program}

FETC initiated the Directives Program at both the Pittsburgh and Morgantown sites in 1997. This process uses total quality management principles to identify and implement standards that will adequately protect workers, the public, and the environment. The starting point is a clear plan for the work to be performed (such as construction, operation, research, or remediation). A team analyzes the work plan to determine potential hazards and identify ways to remove or control those hazards. In addition to this team's analysis, input and suggestions is sought from stakeholders, including members of the public, employees, and union representatives regarding concerns or hazards that must be addressed and approached for ensuring adequate environmental protection. The primary objective of the process is to identify or develop a set of directives that, when implemented, provides reasonable assurance that the health and safety of the workers, public, and the environment will be protected during the performance of the work.

In 1996, FETC identified hazards at both the Pittsburgh and Morgantown sites through distribution of standard forms listing a wide range of possible hazards. Each division or operation was asked to identify possible hazards in their workplace and return the completed forms. The results were used to establish control requirements for all waste activities. The hazard identification process will be repeated during 1999 to ensure that changes to the work environment are adequately addressed. Each employee will be asked to identify possible hazards in their workplace.

In 1998, the risks associated with the hazard identification process were addressed through the development and implementation of a comprehensive set of ES\&H directives at FETC. Although this process is not expected to be completed until early 2000, final directives for Integrated Safety Management, ES\&H Reporting, ES\&H Requirements for Offsite Contractors, R\&D SARS, Life 
Safety Design Criteria, and Work Control were completed during 1998. The development of many other directives were started and reviewed during 1998, a complete cycle from inception to final approval that often takes over a year to complete. Directives receive a rigorous internal review by all internal stakeholders prior to final approval by the FETC Director.

\subsection{Environmental Occurrences}

Notification of environmental occurrences is required under a number of environmental regulations (Pennsylvania, West Virginia, and federal), and the 200 series of DOE Orders including DOE Order 232.1, "Occurrence Reporting and Processing of Operations Information," and DOE Order 231.1, "Environmental, Safety, and Health Reporting."

DOE Order 232.1 provides guidelines to facilities regarding categorization and reporting of environmental occurrences to DOE. The order divides occurrences into three categories: emergencies, unusual occurrences, and off-normal occurrences. FETC maintains an onsite emergency response organization (ERO) at each site (Pittsburgh and Morgantown) that can be called upon 24 hours per day. The ERO is capable of cleaning up or mitigating small spills. If larger spills were to occur, the ERO procedures call for offsite assistance as needed. Once an incident has occurred, the ERO is responsible for categorizing the incident, notifying the proper regulatory agencies, and completing the DOE occurrence reporting.

\subsection{Reported Incidents}

The ERO responded to one environmental incident at the Pittsburgh site during 1998. This was the only occurrence filed during 1998, and did not result in any appreciable damage to the physical environment. This single incident involved the release of non-hazardous coal/water slurry from a site tank truck transporter. The incident occurred on a public easement after the tank truck had been loaded with the slurry mixture at a FETC operation. This incident was categorized as off-normal. It occurred on March 19 on Wallace Road, a public easement running through the Pittsburgh site. The spill involved between ten (10) and fifteen (15) gallons of the non-hazardous material and affected approximately forty (40) feet of easement. The material was immediately removed from the environment and transported off site for final processing.

FETC did not respond to any environmental incidents at the Morgantown site during 1998. Neither of the two occurrence reports filed by FETC for the Morgantown site were the result of an environmental incident.

\subsection{ENVIRONMENTAL MANAGEMENT INFORMATION}

The two FETC sites are staffed by environmental, safety, and health (ES\&H) professionals who review present and past activities to assure that the sites perform their activities in compliance with environmental laws and regulations. All research projects and support activities conducted on site are reviewed by ES\&H staffs in conjunction with the Safety Analysis and Review System (SARS). These activities are carefully reviewed for possible impacts, including impacts on air, surface water, groundwater, and soil. Applicable federal, state, and local regulations potentially 
affecting these activities are reviewed and compliance assured prior to approval by the ES\&H staffs.

\subsection{Environmental Monitoring and Surveillance}

The sites currently monitor their groundwater, stormwater, drinking water, meteorological conditions, and air emissions (based on research project scope) independently at each site. Analyses from several of the groundwater monitoring wells are supplied to the state as information only and are not the result of any consent agreement or permit requirement. A detailed discussion of groundwater monitoring is presented in Section 7.0. FETC monitors its local site outfalls as specified by the requirements of the NPDES permits. Both sites have received "generator only" status, which means that the sites may accumulate hazardous wastes on site for no longer than 90 days. No hazardous waste is treated, stored, or disposed at either the Pittsburgh or the Morgantown site.

\subsection{Integrated Management Activities}

For Fiscal Year 1998, a formalized approach for performance measurement was employed as part of the effort to address performance requirements, such as those mandated by the Government Performance and Results Act. This approach included measurement elements covering management of environmental, safety, and health $(\mathrm{ES} \& \mathrm{H})$ risks associated with implementation of organizational missions. Goals and objectives for ES\&H activities were established and specific performance targets addressing ES\&H risks were included for measurement. Refinements of ES\&H strategies and specific targets to meet the goals and objectives for 1998 were made based on performance results from 1997 and changing organizational initiatives.

To develop an integrated management plan, the ES\&H Functions, Responsibilities, and Authorities Manual (FRAM) was created. This manual, along with other ES\&H organizational and operational information, formed the basis for the Integrated ES\&H Management Plan, issued as a FETC operating plan on July 24, 1998. The Directives Program discussed in Section 3.1 of this report will facilitate the consolidation and standardization of ES\&H procedures.

On a broader level, the Office of Fossil Energy established an ES\&H commitment in April 1997 that addresses environmental protection, pollution prevention, performance standards, tolerance levels for injuries and illnesses, accountability, worker and public participation, and integrated management. As part of the Fossil Energy organization, FETC is dedicated to supporting and implementing this commitment.

\subsection{ENVIRONMENTAL RADIOLOGICAL PROGRAM INFORMATION}

The Atomic Energy Act (AEA) of 1954 and its amendments are the federal laws that mandate that DOE control radioactive materials to protect public safety and health. DOE Orders and EPA and Nuclear Regulatory Commission (NRC) regulations are based on the AEA. Under the AEA, as amended, DOE is responsible for establishing and maintaining an environmental, health, and safety protection program. Furthermore, although DOE facilities are generally exempt from NRC regulations, the facilities are to meet the intent of these regulations. 
Currently, FETC does not generate, transport, process, treat, or have onsite permanent disposal of any radioactive waste. However, FETC does use, in the conduct of research, instrumentation that contains radioactive sources. An inventory of radiation sources is maintained by the Radiation Safety Officer, indicating the item, isotope, quantity, custodian, location, status, and activity. The February 1998 source inventory is provided in Table 6. FETC does not release any radionuclides into the environment as all of its sources are sealed and are used in instrumentation.

The radiation monitoring currently performed at FETC consists of a limited number (less than 20) of personal dosimeter badges and rings supplied under a contract with Siemens Gammasonics, Inc. Additionally, leak testing is conducted on all applicable sealed sources with analysis also performed by Siemens Gammasonics, Inc.

Indoor radon sampling at the Morgantown site was performed in 1994 to screen all facilities on site to determine the indoor radon concentrations and to assess the need for additional follow-up testing. The radon screening conducted at the site covered all buildings and trailers located on site that were occupied or had the potential to be occupied by personnel. The results of the radon testing revealed that none of the buildings had radon levels above the EPA action level of $4 \mathrm{pCi} / \mathrm{L}$. Thus, no follow-up measurements occurred in 1998.

A comprehensive radon screening was performed at the Pittsburgh site in 1990. The results of the radon testing revealed that none of the buildings had levels above the EPA action level of $4 \mathrm{pCi} / \mathrm{L}$.

\section{TABLE 6}

FETC Radioactive Materials Inventory (February 1998)

\begin{tabular}{|c|c|l|c|}
\hline Isotope & Quantity & \multicolumn{1}{|c|}{ Supplier/Source } & Location \\
\hline $\mathrm{Kr}-85$ & 1 & $\begin{array}{l}\text { Model No. 3077 } \\
\text { Serial No. 700T } \\
\text { Thermo-Systems, Inc. }\end{array}$ & MGN \\
\hline $\mathrm{Kr}-85$ & 1 & $\begin{array}{l}\text { Model No. 3012 } \\
\text { Serial No. 467T } \\
\text { Thermo-Systems, Inc. }\end{array}$ & MGN \\
\hline $\mathrm{Kr}-85$ & 1 & $\begin{array}{l}\text { Model No. 3012 } \\
\text { Serial No. 626T } \\
\text { Thermo-Systems, Inc. }\end{array}$ & MGN \\
\hline $\mathrm{Kr}-85$ & 1 & $\begin{array}{l}\text { Model No. 3077 } \\
\text { Serial No. 373T } \\
\text { Thermo-Systems, Inc. }\end{array}$ & MGN \\
\hline $\mathrm{Kr}-85$ & 1 & $\begin{array}{l}\text { Model No. 3077 } \\
\text { Serial No. 697T } \\
\text { Thermo-Systems, Inc. }\end{array}$ & \\
\hline
\end{tabular}


Table 6, continued

\begin{tabular}{|c|c|c|c|}
\hline Isotope & Quantity & Source & Location \\
\hline $\mathrm{Ni}-63$ & 1 & $\begin{array}{l}\text { Model No. } 19233 \\
\text { Serial No. L5470 } \\
\text { Hewlett Packard }\end{array}$ & MGN \\
\hline $\mathrm{Ni}-63$ & 1 & $\begin{array}{l}\text { Model No. } 6000204 \\
\text { Serial No. } 533 \\
\text { Perkin-Elmer Corporation }\end{array}$ & MGN \\
\hline Sc-46 & 1 & $\begin{array}{l}\text { University of Missouri } \\
\text { *Source encapsulated by a } \\
\text { nylon bead. }\end{array}$ & MGN \\
\hline Sc-46 & 1 & $\begin{array}{l}\text { University of Missouri } \\
\text { *Source encapsulated by a } \\
\text { nylon bead. }\end{array}$ & MGN \\
\hline $\mathrm{Ra}-226$ & 1 & $\begin{array}{l}\text { Model No. B-5 } \\
\text { Serial No. } 11205 \\
\text { Mettler Corporation }\end{array}$ & MGN \\
\hline Ra-226 & 1 & $\begin{array}{l}\text { Model No. M-5 } \\
\text { Serial No. } 17032 \\
\text { Mettler Corporation }\end{array}$ & MGN \\
\hline Phosphate Rock & 1 & $\begin{array}{l}\text { Model No. } 1080 \\
\text { Sun Nuclear Corporation }\end{array}$ & MGN \\
\hline $\mathrm{Ni}-63$ & 1 & $\begin{array}{l}\text { Model No. KN2 } \\
\text { Serial No. 107-002-20 } \\
\text { EG\&G, Inc. }\end{array}$ & MGN \\
\hline $\mathrm{Kr}-85$ & 1 & $\begin{array}{l}\text { Model No. OGP-57-3 } \\
\text { Serial No. 9524-001 }\end{array}$ & MGN \\
\hline $\mathrm{Kr}-85$ & 1 & $\begin{array}{l}\text { Model No. OGP-57-3 } \\
\text { Serial No. 9524-002 }\end{array}$ & MGN \\
\hline $\mathrm{H}-3$ & 1 & $\begin{array}{l}\text { Model No. B100/U10 } \\
\text { Serial No. } 575263 \\
\text { SRB Technologies }\end{array}$ & MGN \\
\hline $\mathrm{H}-3$ & 1 & $\begin{array}{l}\text { Model No. B100/U10 } \\
\text { Serial No. } 574434 \\
\text { SRB Technologies }\end{array}$ & MGN \\
\hline $\mathrm{H}-3$ & 1 & $\begin{array}{l}\text { Model No. B100/U10 } \\
\text { Serial No. } 574435 \\
\text { SRB Technologies }\end{array}$ & MGN \\
\hline $\mathrm{H}-3$ & 1 & $\begin{array}{l}\text { Model No. B100/U10 } \\
\text { Serial No. } 574436 \\
\text { SRB Technologies }\end{array}$ & MGN \\
\hline Co-57 & 1 & $\begin{array}{l}\text { Model No. IPL CUS } \\
\text { Serial No. EE661 } \\
\text { Isotope Products Lab }\end{array}$ & MGN \\
\hline
\end{tabular}


Table 6, continued

\begin{tabular}{|c|c|l|c|}
\hline Isotope & Quantity & \multicolumn{1}{|c|}{ Source } & Location \\
\hline \hline $\mathrm{Po}^{210}$ & 4 & Anti-Static Brushes & PGH \\
\hline $\mathrm{Cs}^{137}$ & 3 & $\begin{array}{l}\text { Ronan Engineering Co. Model } \\
137 \\
\text { Level Density Gauge }\end{array}$ & PGH \\
\hline $\mathrm{Cs}^{137}$ & 4 & $\begin{array}{l}\text { Berthold Systems, Inc. Model } \\
\text { LB-7400D } \\
\text { Level/Density Gauges }\end{array}$ & PGH \\
\hline Assorted & 80 & Smoke Detectors & PGH \\
\hline $\mathrm{Ra}^{222}$ & 1 & $\begin{array}{l}\text { LKB Wallac 1214 Rash Beta } \\
\text { Liquid } \\
\text { Scintillation Counter }\end{array}$ & PGH \\
\hline $\mathrm{H}^{3}$ & 1 & Sealed Source of 20 mCi & PGH \\
\hline $\mathrm{Ni}^{63}$ & 1 & $\begin{array}{l}\text { Gas Chromatograph Electron } \\
\text { Capture Device }\end{array}$ \\
\hline
\end{tabular}

\subsection{ENVIRONMENTAL NON-RADIOLOGICAL PROGRAM INFORMATION}

The nonradiological monitoring program at FETC is designed to meet permit requirements and to assess the effectiveness of ongoing waste minimization and pollution prevention programs. The 1998 monitoring program focused on industrial wastewater, stormwater, groundwater, and soil. Specific monitoring and permit information is in Section 2.4 of this report.

\subsection{Clarifier Effluent Monitoring}

The Morgantown site is currently permitted by the Morgantown Utility Board to connect to the city's publicly owned treatment works and is required by that permit to conduct monthly monitoring of the clarifier effluent. Clarifier effluent monitoring parameters and the sampling results are presented in the appendix.

The Pittsburgh site's effluent water consists of a pre-treated industrial wastewater component which is combined with the sanitary wastewater stream. The primary objective of the industrial wastewater monitoring program is to comply with the Pleasant Hills, Pennsylvania, POTW pretreatment requirements.

\subsection{Stormwater Monitoring}

The primary objectives of the stormwater discharge monitoring program are to comply with the multiple federal party NPDES permit. This involves a determination of whether and when onsite stormwater and under drain discharges contain contaminants that could cause potential surface water and sediment contamination tributaries to Lick Run, and ultimately flowing into the Monongahela River. 


\subsection{GROUNDWATER MONITORING AND PROTECTION}

In September 1985, the Secretary of Energy announced a series of initiatives designed to strengthen the ES\&H programs and activities within the U.S. Department of Energy. As required by Chapter III of DOE Order 5400.1, General Environmental Protection Program, FETC developed Groundwater Protection Management Programs at the two sites. The purpose of this order was to establish environmental protection requirements, authorities, and responsibilities for DOE operations and to ensure compliance with applicable federal, state, and local environmental laws; executive orders; and DOE policies. The intent of DOE 5400.1 and the Groundwater Protection Management Program is to ensure that the facilities' RCRA and CERCLA actions are addressed. Based on activities conducted at the sites, FETC is not subject to groundwater monitoring requirements as set forth under RCRA and CERCLA.

\subsection{Groundwater Monitoring}

To date, no significant contamination has been detected in samples collected from any of the groundwater monitoring wells. Results of groundwater monitoring are given in tables in the appendix.

\subsection{Site Hydrology}

Most of Monongalia County is underlain by rocks of low permeability, which consequently yield water at low rates. Wells nearest the Morgantown facility typically have yields of $0.1 \mathrm{~L} / \mathrm{s}$ (1.6 gallons per minute, gpm) or less. The principle aquifers are found in the Pennsylvanian-aged Conemaugh Group and the Pottsville Group. Aquifers of the Conemaugh Group outcrop at the Morgantown site and are the source of most of the domestic water supplies near the area under water table (unconfined) conditions. Aquifers of the Pottsville Group, which are quite deep but are regarded as the most important aquifers in the county, yield up to 250 gpm under artesian pressure but average about $45 \mathrm{gpm}$. The Pottsville Group aquifers are separated from the Conemaugh Group aquifers by several hundred feet of bedrock. There is no apparent communication between these aquifers. Two of the aquifers of the Conemaugh Group are sampled for possible contamination by monitoring wells at FETC, the Morgantown and Grafton sandstones. The recharge area for these two aquifers is east of Morgantown in the area of Chestnut Ridge, and both discharge regionally into the Monongahela River west of the site. The Morgantown sandstone outcrops around the perimeter of the FETC property along Burroughs Run, West Run, and the Monongahela River. There are small springs in a number of places along these creeks and the Monongahela River where water flows from fractures in the Morgantown sandstone. Although the Grafton sandstone outcrops along West Run below its confluence with Burroughs Run, no springs or seeps have been observed there. Most of the discharge from the Grafton aquifer is probably into the bottom of the Monongahela River.

Unconformably overlying the Pennsylvanian rocks at the site is up to 70 feet of Pleistocene-aged unconsolidated Lake Monongahela sediments. These consist of a basal clayey sand which ranges from 10 to 20 feet in thickness, informally named the "A" aquifer, overlying interbedded clays and clayey sands, informally named the "B-C" aquifer, and a predominately sand unit, the "D," which occurs at the surface on the southwest corner of the site. These sediments were deposited in stream and lacustrine environments as a result of the glacial Lake Monongahela. The "A" and "B-C" units are water bearing under the developed part of the site and both are monitored for possible groundwater contamination at FETC. Both units extend off the site, and recharge is 
probably mostly from offsite, as the near-surface sediments are dominated by very low permeability clays in the developed area of the site. Both aquifers outcrop north of the developed area on the property and form springs and small creeks which drain into West Run. There are probably springs and seeps along the Monongahela River from this unit as well.

The groundwater monitoring program provides the following information:

- $\quad$ Baseline conditions of groundwater quality and quantity as related to the site.

- $\quad$ Details of the groundwater/surface water relationship.

- Identification of potential sources of groundwater contamination.

- Data useful in the development an implementation of remedial measures for any FETC facilities/sites that could pose a concern to the environment.

- $\quad$ Measurement of petroleum hydrocarbons (diesel range organics) in groundwater at selected wells surrounding abandoned (or previously removed) storage tanks and oil spill areas, per state request.

There are currently 29 groundwater monitoring wells at various locations throughout the Pittsburgh site. The Groundwater Management Plan implementation included groundwater monitoring well installation, well development, and sampling and analysis to be completed in two phases. Phase I activities occurred from November 16, 1992 through February 12, 1993, and consisted of the installation of 16 bedrock wells, two piezometer clusters, and two stream gauging weirs. Phase II occurred from November 17, 1993 through February 17, 1994 and consisted of 12 additional bedrock wells. A concrete stream gauging station was also constructed during Phase I. Finally, a supplemental well was installed in June 1995.

The Pittsburgh site has two groundwater flow patterns. Groundwater flowing in the shallow, weathered bedrock aquifer may percolate along the soil/bedrock interface and/or along nearvertical stress relief fractures and follows the general site topography, flowing from the tops of hills on the site, generally perpendicular to ground surface elevation contours. This flow is directed by the intervening valleys toward the Lick Run Valley, where it joins the water-bearing unit located in the valley and adds to the baseflow of Lick Run itself. Some of this flow also discharge as springs on the hillsides or in the valleys.

The second flow pattern is associated with the deep aquifer. Groundwater in this zone generally flows east towards the Lick Run Valley, where it is joined by the water of the shallow zone as it flows off the hillsides.

For purposes of groundwater monitoring, the Pittsburgh site is broken down into three separate areas generally referred to as the Main Plateau area, the Valley Fill area (which includes the 900 Area, Building 141, and the 920 Area, 2.1 Acre, 2.2 Acre, and 4.0 Acre Properties), and the Building 167/Triangle Parking Lot area. These areas were selected based on current operations and historical areas of contamination. During 1998, a semiannual groundwater sampling and analysis program involving two contamination detection programs was completed. 
Tables in the appendix present the results of groundwater data collected. This analysis consisted of the following:

(1) Investigation for immiscible (light or dense) organic phases, continued measurement for specific constituents identified during the initial monitoring phase, RCRA (background year) sampling/analyses, and subsequent RCRA sampling/analyses with statistical comparisons of contamination indicator parameter data.

(2) Measurement of petroleum hydrocarbons (diesel range organics) in groundwater at selected wells surrounding inactive underground storage tanks and oil spill areas, per PaDEP request.

Results of laboratory analyses produce a variety of groundwater chemical constituent data that must be evaluated to determine whether the facility is contaminating the groundwater.

Downgradient contamination is indicated by one, or a combination of, the following conditions:

- Immiscible organic phases are detected downgradient and contaminant concentrations are substantively elevated compared to upgradient/background (or none detected upgradient) and substantively exceed drinking water standard maximum contaminant levels (MCLs).

- Dissolved Hazardous Waste Appendix IX hazardous constituents are detected downgradient and concentrations are substantively elevated compared to upgradient/background (or none detected upgradient) and substantively exceed MCLs (or human health evaluations identify a risk).

Statistical comparisons of semiannual contamination indicator data (upgradient and downgradient wells) are made against appropriate upgradient/background well data. If statistically significant downgradient differences exist (and are subsequently confirmed by immediate resampling and repeating of statistical analyses) then contamination will be indicated and a human health and ecological risk assessment and/or groundwater quality assessment program would be warranted. If no downgradient statistically significant differences are calculated, routine monitoring will continue. 


\section{ACRONYMS AND ABBREVIATIONS}

\begin{tabular}{|c|c|}
\hline ACHD & Allegheny County (Pennsylvania) Health Department \\
\hline AEA & Atomic Energy Act \\
\hline ARAR & Applicable or Relevant and Appropriate Requirements \\
\hline AST & Aboveground Storage Tank \\
\hline BOD & Biological Oxygen Demand \\
\hline BPT & Best Practicable Technology \\
\hline CAA & Clean Air Act \\
\hline CERCLA & The Comprehensive Environmental Response, Compensation and Liability Act \\
\hline CFC & Chlorofluorohydrocarbans \\
\hline CHF & Chemical Handling Facility (FETC-PGH) \\
\hline COD & Chemical Oxygen Demand \\
\hline COR & (DOE/FETC) Contracting Officer Representative \\
\hline $\mathbf{C X}$ & NEPA Category Exclusion \\
\hline DMR & Discharge Monitoring Report \\
\hline DNR & (West Virginia) Department of Natural Resources \\
\hline DOE & Department of Energy \\
\hline EA & Environmental Assessment \\
\hline EG\&G & EG\&G Technical Services Corporation \\
\hline EIS & Environmental Impact Statement \\
\hline EPA & United States Environmental Protection Agency \\
\hline EPCRA & Emergency Planning and Community Right to Know \\
\hline ESA & Endangered Species Act \\
\hline ES\&H & Environment, Safety, \& Health \\
\hline FETC & Federal Energy Technology Center \\
\hline FFCA & Federal Facilities Compliance Act \\
\hline FIFRA & Federal Insecticide, Fungicide, and Rodenticide Act \\
\hline FONSI & Finding of No Significant Impact \\
\hline GMP & Groundwater Protection Management Plan \\
\hline HVAC & Heating, Ventilation and Air Conditioning \\
\hline LEPC & Local Emergency Planning Committee \\
\hline MCL & Maximum Contaminant Level \\
\hline MGN & Federal Energy Technology Center in Morgantown, West Virginia \\
\hline MSC & Medium Specific Concentration \\
\hline MSDS & Material Safety Data Sheet \\
\hline MSHA & (United States) Mine Safety and Health Administration \\
\hline MUB & Morgantown Utility Board \\
\hline NEPA & National Environmental Policy Act \\
\hline NESHAP & National Emission Standards for Hazardous Air Pollutants \\
\hline NHPA & National Historic Preservation Act \\
\hline NIOSH & National Institute for Occupational Safety and Health \\
\hline NPDES & National Pollutant Discharge Elimination System \\
\hline NPL & National Priority List \\
\hline
\end{tabular}




$\begin{array}{ll}\text { NRC } & \text { Nuclear Regulatory Commission } \\ \text { OAQ } & \text { (West Virginia) Office of Air Quality } \\ \text { ORPS } & \text { Occurrence Reporting and Processing System } \\ \text { OSHA } & \text { (United States) Occupational Safety and Health Administration } \\ \text { PaDEP } & \text { Pennsylvania Department of Environmental Protection } \\ \text { PA } & \text { Preliminary Assessment } \\ \text { Part B } & \\ \text { Facility } & \text { Treatment, Storage, and Disposal Facility } \\ \text { PCB } & \text { Polychlorinated Biphenyl } \\ \text { PDU } & \text { Process Development Unit } \\ \text { PGH } & \text { Federal Energy Technology Center in Pittsburgh, Pennsylvania } \\ \text { PHA } & \text { Pleasant Hills (Pennsylvania) Authority } \\ \text { POTW } & \text { Publicly Owned Treatment Works } \\ \text { PP } & \text { Pollution Prevention } \\ \text { R\&D } & \text { Research and Development } \\ \text { RCRA } & \text { Resource Conservation and Recovery Act } \\ \text { SARA } & \text { Superfund Amendments and Reauthorization Act } \\ \text { SDWA } & \text { Safe Drinking Water Act } \\ \text { SEA } & \text { Site Evaluation Accomplished } \\ \text { SER } & \text { Site Environmental Report } \\ \text { SERC } & \text { State Emergency Response Commission } \\ \text { SSAI } & \text { Site Sampling and Analysis Investigation } \\ \text { SAP } & \text { Sampling and Analysis Plan } \\ \text { SVOC } & \text { Semivolatile Organic Compounds } \\ \text { TPH } & \text { Total Petroleum Hydrocarbons } \\ \text { TPQ } & \text { Threshold Planning Quantity } \\ \text { TRI } & \text { Toxic Release Inventory } \\ \text { TSCA } & \text { Toxic Substances Control Act } \\ \text { TSD } & \text { Treatment, Storage, and Disposal Facility } \\ \text { TSS } & \text { Total Suspended Solids } \\ \text { TVA } & \text { Tennessee Valley Authority } \\ \text { UCG } & \text { Underground Coal Gasification } \\ \text { UST } & \text { Underground Storage Tank } \\ \text { USTMP } & \text { Underground Storage Tank Management Plan } \\ \text { VOC } & \text { Volatile Organic Compounds } \\ \text { WDEQ } & \text { Wyoming Department of Environmental Quality } \\ \text { WVDEP } & \text { West Virginia Department of Environmental Protection } \\ & \end{array}$


APPENDIX 
TABLE 7

FETC-PGH 1998 National Pollutant Discharge

Elimination System Storm Water Analysis Results

\begin{tabular}{|c|c|c|c|c|}
\hline \multirow[b]{2}{*}{ Constituent } & \multicolumn{4}{|c|}{ Sample Date } \\
\hline & $4 / 8 / 98$ & $6 / 26 / 98$ & $8 / 24 / 98$ & $12 / 8 / 98$ \\
\hline \multicolumn{5}{|c|}{ North Outfall } \\
\hline Flow & 0.243 MGD & 43.878 MGD & $1.931 \mathrm{MGD}$ & $0.281 \mathrm{MGD}$ \\
\hline Suspended Solids & $41 \mathrm{mg} / \mathrm{l}$ & 478 mg/l & 42 mg/l & $5 \mathrm{mg} / \mathrm{l}$ \\
\hline CBOD5 & $34 \mathrm{mg} / \mathrm{l}$ & $20 \mathrm{mg} / \mathrm{l}$ & $6 \mathrm{mg} / \mathrm{l}$ & $5 \mathrm{mg} / \mathrm{l}$ \\
\hline Oil \& Grease & 3.2 mg/l & $<5.0 \mathrm{mg} / \mathrm{l}$ & $1 \mathrm{mg} / \mathrm{l}$ & $<1 \mathrm{mg} / \mathrm{l}$ \\
\hline Aluminum & $0.40 \mathrm{mg} / \mathrm{l}$ & 1.0 mg/l & $1.00 \mathrm{mg} / \mathrm{l}$ & $0.11 \mathrm{mg} / \mathrm{l}$ \\
\hline Iron & $0.94 \mathrm{mg} / \mathrm{l}$ & $1.8 \mathrm{mg} / \mathrm{l}$ & $2.31 \mathrm{mg} / \mathrm{l}$ & $0.54 \mathrm{mg} / \mathrm{l}$ \\
\hline Manganese & $0.31 \mathrm{mg} / \mathrm{l}$ & $0.37 \mathrm{mg} / \mathrm{l}$ & $0.20 \mathrm{mg} / \mathrm{l}$ & $0.33 \mathrm{mg} / \mathrm{l}$ \\
\hline Lead & 18 ug/l & 23 ug/l & $<5 \mathrm{ug} / \mathrm{l}$ & $<1 \mathrm{ug} / \mathrm{l}$ \\
\hline Mercury & $<0.2 \mathrm{ug} / \mathrm{l}$ & $<0.2 \mathrm{ug} / \mathrm{l}$ & $1.1 \mathrm{ug} / \mathrm{l}$ & $<2 \mathrm{ug} / \mathrm{l}$ \\
\hline $\mathrm{pH}$ & 7.05 s.u. & 6.90 s.u. & 7.24 s.u. & 7.09 s.u. \\
\hline \multicolumn{5}{|c|}{ South Outfall } \\
\hline Flow & 2.105 MGD & 2.817 MGD & 1.125 MGD & 0.289 MGD \\
\hline Suspended Solids & 125 mg/l & 730 mg/l & 22 mg/l & 22 mg/l \\
\hline Aluminum & $6.7 \mathrm{mg} / \mathrm{l}$ & $2.0 \mathrm{mg} / \mathrm{l}$ & $1.74 \mathrm{mg} / \mathrm{l}$ & $0.73 \mathrm{mg} / \mathrm{l}$ \\
\hline Iron & $2.3 \mathrm{mg} / \mathrm{l}$ & $1.9 \mathrm{mg} / \mathrm{l}$ & $1.19 \mathrm{mg} / \mathrm{l}$ & $0.77 \mathrm{mg} / \mathrm{l}$ \\
\hline Manganese & $0.35 \mathrm{mg} / \mathrm{l}$ & $0.54 \mathrm{mg} / \mathrm{l}$ & $0.21 \mathrm{mg} / \mathrm{l}$ & $0.22 \mathrm{mg} / \mathrm{l}$ \\
\hline Lead & 42 ug/l & 22 ug/l & 7 ug/l & 3 ug/l \\
\hline $\mathrm{pH}$ & 7.27 s.u. & 7.19 s.u. & 7.46 s.u. & 7.85 s.u. \\
\hline
\end{tabular}


TABLE 8

FETC-PGH 1998 Wastewater Effluent Analysis (MG/L)

\begin{tabular}{|c|c|c|c|c|c|c|c|c|c|c|c|c|c|}
\hline Constituent & Standard/Guideline & January & February & March & April & May & June & July & August & September & October & November & December \\
\hline Sampling Date & & $01 / 26 / 98$ & $02 / 23 / 98$ & $03 / 18 / 98$ & $04 / 23 / 98$ & $05 / 26 / 98$ & $06 / 30 / 98$ & $07 / 28 / 98$ & $08 / 25 / 98$ & $09 / 24 / 98$ & $10 / 29 / 98$ & $11 / 23 / 98$ & $12 / 29 / 98$ \\
\hline \multicolumn{14}{|c|}{ Building 74 Wastewater Treatment Facility Effluent } \\
\hline Aluminum & None & 0.16 & $<0.1$ & 0.12 & $<0.1$ & $<0.1$ & 0.18 & 0.22 & 0.18 & 0.32 & $<0.1$ & 0.19 & 0.19 \\
\hline Cadium & 0.02 & $<0.005$ & $<0.005$ & $<0.005$ & $<0.005$ & $<0.005$ & $<0.005$ & $<0.005$ & $<0.005$ & $<0.005$ & $<0.005$ & $<0.005$ & $<0.005$ \\
\hline Chromium & 0.5 & $<0.01$ & $<0.01$ & $<0.01$ & $<0.01$ & $<0.01$ & $<0.01$ & $<0.01$ & $<0.01$ & $<0.01$ & $<0.01$ & 0.01 & $<0.01$ \\
\hline Copper & 0.5 & 0.10 & 0.02 & 0.05 & 0.10 & 0.03 & 0.04 & 0.04 & 0.06 & 0.04 & 0.02 & 0.20 & 0.09 \\
\hline Cyanide & 0.5 & $<0.005$ & $<0.005$ & $<0.005$ & $<0.005$ & $<0.005$ & $<0.005$ & $<0.005$ & $<0.005$ & $<0.005$ & $<0.005$ & $<0.005$ & $<0.005$ \\
\hline TOX & None & 0.183 & 0.089 & 0.230 & 0.138 & 0.073 & 0.135 & 0.322 & 0.137 & 0.269 & 0.159 & 142 & 0.122 \\
\hline Iron & 7.0 & 0.67 & 0.47 & 1.09 & 0.68 & 0.54 & 0.48 & 3.75 & 0.73 & 4.16 & 1.10 & 2.08 & 1.09 \\
\hline Lead & 0.1 & 0.03 & 0.02 & $<0.015$ & 0.010 & $<0.005$ & 0.006 & $<0.015$ & $<0.015$ & 0.054 & $<0.015$ & 0.018 & $<0.015$ \\
\hline Mercury & None & 0.0005 & $<0.0002$ & 0.0005 & 0.0005 & $<0.0002$ & 0.0003 & 0.0002 & $<0.0002$ & 0.0005 & 0.0003 & 0.0071 & 0.0035 \\
\hline Nickel & 1.5 & 0.03 & $<0.02$ & $<0.02$ & $<0.02$ & $<0.02$ & $<0.02$ & $<0.02$ & $<0.02$ & $<0.02$ & $<0.02$ & $<0.02$ & $<0.02$ \\
\hline Oil \& Grease & None & $<5$ & $<5$ & $<5$ & $<5$ & $<5$ & $<5$ & $<5$ & $<5$ & 6 & $<5$ & $<5$ & $<5$ \\
\hline $\mathrm{pH}$ (s.u.) & $>5.0$ & 7.6 & 7.4 & 7.5 & 9.2 & 7.8 & 7.9 & 8.0 & 7.9 & 8.0 & 7.7 & 7.7 & 7.8 \\
\hline Phenolics & None & $<0.005$ & $<0.005$ & NS & $<0.005$ & $<0.005$ & $<0.005$ & $<0.005$ & $<0.005$ & $<0.005$ & 0.008 & $<0.005$ & $<0.005$ \\
\hline TSS & None & $<5$ & 28 & 6 & $<5$ & $<5$ & 5 & 15 & 6 & 13 & $<5$ & 11 & $<5$ \\
\hline Tin & 2.0 & $<0.01$ & $<0.01$ & $<0.01$ & $<0.01$ & 0.45 & 0.01 & $<0.01$ & 0.020 & 0.069 & $<0.01$ & $<0.01$ & $<0.01$ \\
\hline Trichloromethane & None & $<0.005$ & $<0.005^{*}$ & $<0.005$ & 0.010 & $<0.005$ & 0.021 & 0.008 & 0.015 & $<0.005$ & $<0.005$ & 0.109 & $<0.005$ \\
\hline Zinc & 1.0 & 0.257 & 0.241 & 0.227 & 0.175 & 0.273 & 0.361 & 0.072 & 0.181 & 0.120 & 0.165 & 0.375 & 0.247 \\
\hline
\end{tabular}

NS - Not Sampled.

* - Sampled on 03/06/98 Standard/Guideline - Pleasant Hills Authority Pretreatment Ordinance, November 16, 1998. 
TABLE 8 (continued)

FETC-PGH 1998 Wastewater Effluent Analysis (MG/L)

\begin{tabular}{|c|c|c|c|c|c|c|c|c|c|c|c|c|c|}
\hline \multicolumn{14}{|c|}{ Building 141 Laboratory Wastewater Holding Tank } \\
\hline \multicolumn{2}{|c|}{ Sampling Date } & $01 / 16 / 98$ & NS & $03 / 05 / 98$ & $04 / 07 / 98$ & $05 / 26 / 98$ & $06 / 18 / 98$ & $07 / 28 / 98$ & NS & $09 / 01 / 98$ & $10 / 29 / 98$ & NS & NS \\
\hline Aluminum & None & $<0.1$ & NS & $<0.1$ & 0.12 & $<0.1$ & $<0.1$ & 0.79 & NS & 0.12 & 0.41 & NS & NS \\
\hline Cadium & 0.02 & $<0.005$ & NS & $<0.005$ & $<0.005$ & $<0.005$ & $<0.005$ & $<0.005$ & NS & $<0.005$ & $<0.005$ & NS & NS \\
\hline Chromium & 0.5 & $<0.01$ & NS & $<0.01$ & $<0.01$ & $<0.01$ & $<0.01$ & 0.01 & NS & $<0.01$ & 0.01 & NS & NS \\
\hline Copper & 0.5 & 0.05 & NS & 0.06 & 0.10 & 0.07 & 0.05 & 0.20 & NS & 0.08 & 0.20 & NS & NS \\
\hline Cyanide & 0.5 & $<0.005$ & NS & $<0.005$ & $<0.005$ & $<0.005$ & $<0.005$ & $<0.005$ & NS & $<0.005$ & $<0.005$ & NS & NS \\
\hline TOX & None & 0.170 & NS & NS & 0.030 & 0.073 & 0.069 & 0.157 & NS & 0.084 & 0.132 & NS & $\mathrm{NS}$ \\
\hline Iron & 7.0 & 5.06 & NS & 0.87 & 3.45 & 2.59 & 1.75 & 23.5 & NS & 3.00 & 16.5 & NS & NS \\
\hline Lead & 0.1 & $<0.015$ & NS & $<0.015$ & 0.01 & $<0.005$ & $<0.005$ & $<0.015$ & NS & $<0.015$ & 0.0015 & NS & NS \\
\hline Mercury & None & $<0.0002$ & NS & $<0.0002$ & 0.0011 & 0.0003 & 0.0002 & 0.0008 & NS & 0.0004 & 0.0014 & NS & NS \\
\hline Nickel & 1.5 & $<0.02$ & NS & $<0.02$ & $<0.02$ & $<0.02$ & $<0.02$ & $<0.02$ & NS & $<0.02$ & $<0.02$ & NS & NS \\
\hline Oil \& Grease & None & $<5$ & NS & NS & $<5$ & $<5$ & $<5$ & 11 & NS & 6 & 16 & NS & NS \\
\hline $\mathrm{pH}$ (s.u.) & $>5.0$ & 7.5 & NS & 7.7 & 9.6 & 7.4 & 7.8 & 7.7 & NS & 7.4 & 7.6 & NS & NS \\
\hline Phenolics & None & 0.009 & NS & NS & 0.028 & 0.017 & 0.008 & 0.030 & NS & 0.018 & 0.037 & NS & NS \\
\hline TSS & None & 35 & NS & 10 & 34 & 19 & 6 & 75 & NS & $<5$ & 34 & NS & NS \\
\hline Tin & 2.0 & $<0.01$ & NS & $<0.01$ & $<0.01$ & $<0.01$ & $<0.01$ & $<0.01$ & NS & $<0.01$ & $<0.01$ & NS & NS \\
\hline Trichloromethane & None & $<0.005$ & NS & $<0.005$ & $<0.005$ & $<0.005$ & $<0.005$ & 0.007 & NS & $<0.005$ & $<0.005$ & NS & NS \\
\hline Zinc & 1.0 & 0.060 & NS & 0.049 & 0.104 & 0.061 & 0.078 & 0.233 & NS & 0.350 & 0.238 & NS & NS \\
\hline
\end{tabular}

NS - Not Sampled.

* - Sampled on 03/06/98 Standard/Guideline - Pleasant Hills Authority Pretreatment Ordinance, November 16, 1998. 
TABLE 9

FETC-PGH 1998 Groundwater Detection Monitoring Program

Results of Analysis - Groundwater Samples

Main Plateau - Contamination Indicator Constituents

\begin{tabular}{|c|c|c|c|c|c|c|c|c|c|c|c|c|c|c|}
\hline \multirow[t]{2}{*}{ Week } & \multirow{2}{*}{$\begin{array}{r}\text { Constituents } \\
\text { Well } \\
\text { Sample Event } \\
\text { Sample Date } \\
\end{array}$} & \multicolumn{2}{|c|}{ MPW-1 } & \multirow{2}{*}{$\begin{array}{c}\text { MPW-1-1 } \\
\text { Round } 1 \\
\text { N/A } \\
\end{array}$} & \multicolumn{2}{|c|}{ MPW-2 } & \multirow{2}{*}{$\begin{array}{c}\text { MPW-2-1 } \\
\text { Round } 2 \\
9 / 29 / 98 \\
\end{array}$} & \multicolumn{2}{|c|}{ MPW-3 } & \multicolumn{2}{|c|}{ MPW-4 } & \multirow{2}{*}{$\begin{array}{c}\text { MPW-4-1 } \\
\text { Round } 2 \\
\text { N/A } \\
\end{array}$} & \multicolumn{2}{|c|}{ MPW-4D } \\
\hline & & $\begin{array}{c}\text { Round } 1 \\
4 / 28 / 98 \\
\end{array}$ & $\begin{array}{c}\text { Round } 2 \\
9 / 29 / 98 \\
\end{array}$ & & $\begin{array}{c}\text { Round } 1 \\
4 / 28 / 98 \\
\end{array}$ & $\begin{array}{c}\text { Round } 2 \\
9 / 29 / 98 \\
\end{array}$ & & $\begin{array}{c}\text { Round } 1 \\
4 / 28 / 98 \\
\end{array}$ & $\begin{array}{r}\text { Round } 2 \\
9 / 29 / 98 \\
\end{array}$ & $\begin{array}{c}\text { Round } 1 \\
4 / 29 / 98 \\
\end{array}$ & $\begin{array}{c}\text { Round } 2 \\
9 / 30 / 98 \\
\end{array}$ & & $\begin{array}{c}\text { Round } 1 \\
4 / 29 / 98 \\
\end{array}$ & $\begin{array}{r}\text { Round } 2 \\
9 / 30 / 98 \\
\end{array}$ \\
\hline \multirow{5}{*}{ Week 1} & $\mathrm{pH}$ (Standard Unit) & 7.19 & 7.02 & $\mathrm{~N} / \mathrm{A}$ & 6.84 & 6.57 & 6.57 & 8.34 & 8.23 & 7.11 & 7.04 & N/A & 8.20 & 8.10 \\
\hline & Specific Conductance & 3130 & 3590 & N/A & 1610 & 2490 & 2490 & 960 & 1600 & 2190 & 2300 & N/A & 840 & 700 \\
\hline & TOX (ug/l) & 200 & 930 & $\mathrm{~N} / \mathrm{A}$ & 120 & 78 & 630 & 22 & 200 & 190 & 130 & N/A & 54 & 130 \\
\hline & TOC (mg/l) & 1.2 & 1.1 & $\mathrm{~N} / \mathrm{A}$ & $0.93 \mathrm{~J}$ & 1.4 & 1.4 & 2.4 & 2.0 & 1.4 & 1.4 & N/A & 1.3 & 1.5 \\
\hline & Sample Date & $5 / 5 / 98$ & $10 / 6 / 98$ & N/A & $5 / 5 / 98$ & $10 / 6 / 98$ & N/A & 5/5-6/98 & Abandoned & $5 / 5 / 98$ & $10 / 6 / 98$ & N/A & $5 / 5 / 98$ & $10 / 6 / 98$ \\
\hline \multirow{5}{*}{ Week 2} & $\mathrm{pH}$ (Standard Unit) & 7.01 & 6.75 & N/A & 6.88 & 6.72 & N/A & 8.49 & Abandoned & 7.10 & 6.83 & N/A & 8.14 & 8.11 \\
\hline & Specific Conductance & 3550 & 3630 & N/A & 2970 & 2440 & N/A & 920 & Abandoned & 2190 & 1100 & N/A & 570 & 900 \\
\hline & TOX (ug/l) & 190 & 1500 & N/A & 180 & 160 & N/A & 23 & Abandoned & 130 & 190 & N/A & 34 & 140 \\
\hline & TOC (mg/l) & 1.2 & 1.1 & $\mathrm{~N} / \mathrm{A}$ & 1.2 & 1.3 & $\mathrm{~N} / \mathrm{A}$ & 1.8 & Abandoned & 1.1 & 1.1 & N/A & 1.4 & 1.3 \\
\hline & Sample Date & $5 / 12 / 98$ & $10 / 14 / 98$ & N/A & $5 / 12 / 98$ & $10 / 14 / 98$ & N/A & $5 / 12 / 98$ & Abandoned & $5 / 12 / 98$ & $10 / 14 / 98$ & $10 / 14 / 98$ & $5 / 12 / 98$ & $10 / 14 / 98$ \\
\hline \multirow{5}{*}{ Week 3} & $\mathrm{pH}$ (Standard Unit) & 7.34 & 6.72 & N/A & 6.85 & 6.56 & $\mathrm{~N} / \mathrm{A}$ & 8.48 & Abandoned & 7.11 & 6.78 & 6.78 & 8.23 & 7.85 \\
\hline & Specific Conductance & 3370 & 3660 & $\mathrm{~N} / \mathrm{A}$ & 2840 & 3410 & $\mathrm{~N} / \mathrm{A}$ & 1650 & Abandoned & 2110 & 2210 & 2210 & 830 & 900 \\
\hline & TOX (ug/l) & 200 & 730 & $\mathrm{~N} / \mathrm{A}$ & 97 & 1100 & $\mathrm{~N} / \mathrm{A}$ & 17 & Abandoned & 120 & 1300 & 1300 & 60 & 480 \\
\hline & TOC $(\mathrm{mg} / \mathrm{l})$ & 1.0 & 1.6 & N/A & 1.2 & 1.4 & $\mathrm{~N} / \mathrm{A}$ & 3.0 & Abandoned & 1.3 & 1.5 & 1.4 & 1.7 & 1.3 \\
\hline & Sample Date & $5 / 19 / 98$ & $10 / 20 / 98$ & $5 / 19 / 98$ & $5 / 19 / 98$ & $10 / 20 / 98$ & $\mathrm{~N} / \mathrm{A}$ & 5/19/98 & Abandoned & $5 / 19 / 98$ & $10 / 20 / 98$ & N/A & $5 / 19 / 98$ & $10 / 20 / 98$ \\
\hline \multirow{4}{*}{ Week 4} & $\mathrm{pH}$ (Standard Unit) & 7.31 & 6.71 & 7.31 & 6.82 & 6.67 & $\mathrm{~N} / \mathrm{A}$ & 8.39 & Abandoned & 7.10 & 6.92 & N/A & 8.34 & 8.10 \\
\hline & Specific Conductance & 3390 & 3840 & 3390 & 2750 & 2640 & N/A & 1040 & Abandoned & 2150 & 2190 & N/A & 870 & 920 \\
\hline & TOX (ug/l) & 830 & 1500 & 940 & 180 & 440 & N/A & $\mathrm{NS}$ & Abandoned & 190 & 360 & N/A & 49 & 290 \\
\hline & TOC $(\mathrm{mg} / \mathrm{l})$ & $<1.0$ & $<1.0$ & $<1.0$ & $<1.0$ & 1.1 & $\mathrm{~N} / \mathrm{A}$ & NS & Abandoned & 1.6 & $<1.0$ & N/A & $<1.0$ & $<1.0$ \\
\hline \multirow{4}{*}{1998 Range } & $\mathrm{pH}$ (Standard Unit) & \multicolumn{2}{|l|}{$6.71-7.34$} & $\mathrm{~N} / \mathrm{A}$ & \multicolumn{2}{|l|}{$6.56-6.88$} & $\mathrm{~N} / \mathrm{A}$ & $8.23-8.49$ & & \multicolumn{2}{|c|}{$6.78-7.11$} & N/A & \multicolumn{2}{|l|}{$7.85-8.34$} \\
\hline & Specific Conductance & \multicolumn{2}{|c|}{$3130-3840$} & $\mathrm{~N} / \mathrm{A}$ & \multicolumn{2}{|c|}{$1610-3410$} & N/A & $920-1650$ & & \multicolumn{2}{|c|}{$1100-2300$} & N/A & \multicolumn{2}{|l|}{$570-920$} \\
\hline & TOX (ug/l) & \multicolumn{2}{|l|}{$190-1500$} & N/A & \multicolumn{2}{|l|}{$78-1100$} & $\mathrm{~N} / \mathrm{A}$ & $17-200$ & & \multicolumn{2}{|c|}{$120-1300$} & N/A & \multicolumn{2}{|l|}{$34-480$} \\
\hline & TOC (mg/l) & \multicolumn{2}{|l|}{$<1.0-1.6$} & N/A & \multicolumn{2}{|l|}{$0.93-1.4$} & N/A & $1.8-3.0$ & & $<1$. & 1.6 & N/A & $<1.0-1.7$ & \\
\hline
\end{tabular}

Specific Conductance unit: umhos $/ \mathrm{cm} @ 25^{\circ} \mathrm{C}$

J - Quantitative estimate.

N/A - Not applicable.

$\mathrm{U}$ - Not detected. 
TABLE 9 (continued)

Results of Analysis - Groundwater Samples

Main Plateau (Continued) - Contamination Indicator Constituents

\begin{tabular}{|c|c|c|c|c|c|c|c|c|c|c|c|c|}
\hline \multirow[t]{2}{*}{ Week } & \multirow{2}{*}{$\begin{array}{r}\text { Constituents } \\
\text { Well } \\
\text { Sample Event } \\
\text { Sample Date } \\
\end{array}$} & \multicolumn{2}{|c|}{ MPW-6 } & \multirow{2}{*}{$\begin{array}{c}\text { MPW-6-1 } \\
\text { Round } 1 \\
\text { 4/29/98 } \\
\end{array}$} & \multicolumn{2}{|c|}{ MPW-6D } & \multicolumn{2}{|c|}{ MPW-7 } & \multirow{2}{*}{$\begin{array}{c}\text { MPW-7-1 } \\
\text { Round } 1 \\
\text { N/A } \\
\end{array}$} & \multicolumn{2}{|c|}{ MPW-7D } & \multirow{2}{*}{$\begin{array}{c}\text { MPW-7D-1 } \\
\text { Round } 2 \\
\text { N/A } \\
\end{array}$} \\
\hline & & $\begin{array}{c}\text { Round } 1 \\
4 / 29 / 98 \\
\end{array}$ & $\begin{array}{c}\text { Round } 2 \\
9 / 29 / 98 \\
\end{array}$ & & $\begin{array}{c}\text { Round } 1 \\
4 / 29 / 98 \\
\end{array}$ & $\begin{array}{r}\text { Round } 2 \\
9 / 29 / 98 \\
\end{array}$ & $\begin{array}{c}\text { Round } 1 \\
4 / 29 / 98 \\
\end{array}$ & $\begin{array}{l}\text { Round } 2 \\
9 / 29 / 98 \\
\end{array}$ & & $\begin{array}{c}\text { Round } 1 \\
4 / 29 / 98 \\
\end{array}$ & $\begin{array}{r}\text { Round } 2 \\
9 / 29 / 98 \\
\end{array}$ & \\
\hline \multirow{5}{*}{ Week 1} & $\mathrm{pH}$ (Standard Unit) & 7.29 & 7.39 & 7.29 & 8.92 & 8.85 & 6.80 & 6.42 & N/A & 6.85 & 6.88 & N/A \\
\hline & Specific Conductance & 660 & 720 & 660 & 880 & 920 & 1810 & 1400 & N/A & 1440 & 1440 & N/A \\
\hline & TOX (ug/l) & 28 & 140 & 49 & 35 & 39 & 170 & 140 & N/A & 110 & 150 & N/A \\
\hline & TOC $(\mathrm{mg} / \mathrm{l})$ & 1.3 & 3.7 & 1.2 & 1.5 & 1.9 & 3.9 & 4.2 & N/A & 1.5 & 1.3 & N/A \\
\hline & Sample Date & $5 / 5 / 98$ & Abandoned & N/A & $5 / 5 / 98$ & Abandoned & $5 / 5 / 98$ & $10 / 6 / 98$ & $5 / 5 / 98$ & $5 / 5 / 98$ & $10 / 6 / 98$ & N/A \\
\hline \multirow{5}{*}{ Week 2} & $\mathrm{pH}$ (Standard Unit) & 7.42 & Abandoned & N/A & 8.97 & Abandoned & 6.89 & 6.65 & 6.89 & 6.95 & 6.86 & $\mathrm{~N} / \mathrm{A}$ \\
\hline & Specific Conductance & 690 & Abandoned & $\mathrm{N} / \mathrm{A}$ & 890 & Abandoned & 1850 & 2150 & 1850 & 1480 & 1680 & N/A \\
\hline & TOX (ug/l) & 30 & Abandoned & N/A & $7.8 \mathrm{~J}$ & Abandoned & 85 & 1500 & 94 & 63 & 1100 & N/A \\
\hline & TOC $(\mathrm{mg} / \mathrm{l})$ & $0.84 \mathrm{~J}$ & Abandoned & N/A & $0.99 \mathrm{~J}$ & Abandoned & 3.7 & 1.5 & 4.7 & 1.2 & 1.4 & N/A \\
\hline & Sample Date & $5 / 12 / 98$ & Abandoned & $\mathrm{N} / \mathrm{A}$ & $5 / 12 / 98$ & Abandoned & $5 / 12 / 98$ & $10 / 14 / 98$ & N/A & $5 / 12 / 98$ & $10 / 14 / 98$ & N/A \\
\hline \multirow{5}{*}{ Week 3} & $\mathrm{pH}$ (Standard Unit) & 7.34 & Abandoned & N/A & 8.96 & Abandoned & 6.91 & 6.62 & N/A & 6.89 & 6.82 & N/A \\
\hline & Specific Conductance & 380 & Abandoned & N/A & 890 & Abandoned & 1900 & 2080 & N/A & 760 & 1720 & N/A \\
\hline & TOX (ug/l) & 39 & Abandoned & N/A & 34 & Abandoned & 100 & 750 & N/A & 94 & 580 & N/A \\
\hline & TOC (mg/l) & 1.1 & Abandoned & N/A & 1.2 & Abandoned & 2.7 & 2.1 & N/A & 1.1 & 1.4 & N/A \\
\hline & Sample Date & $5 / 19 / 98$ & Abandoned & N/A & $5 / 19 / 98$ & Abandoned & $5 / 19 / 98$ & $10 / 20 / 98$ & N/A & $5 / 19 / 98$ & $10 / 20 / 98$ & $10 / 20 / 98$ \\
\hline \multirow{4}{*}{ Week 4} & $\mathrm{pH}$ (Standard Unit) & 7.37 & Abandoned & N/A & 9.02 & Abandoned & 6.80 & 6.67 & N/A & 7.01 & 6.86 & 6.86 \\
\hline & Specific Conductance & 640 & Abandoned & N/A & 930 & Abandoned & 2370 & 1690 & N/A & 1400 & 1670 & 1670 \\
\hline & TOX (ug/l) & 38 & Abandoned & N/A & 200 & Abandoned & 220 & 980 & N/A & 130 & 800 & 740 \\
\hline & TOC (mg/l) & $<1.0$ & Abandoned & N/A & 1.8 & Abandoned & 2.2 & 2.0 & N/A & 1.2 & 1.1 & 1.5 \\
\hline \multirow{4}{*}{1998 Range } & $\mathrm{pH}$ (Standard Unit) & \multicolumn{2}{|c|}{$7.29-7.42$} & N/A & \multicolumn{2}{|c|}{$8.85-9.02$} & \multicolumn{2}{|c|}{$6.42-6.91$} & N/A & \multicolumn{2}{|c|}{$6.82-7.01$} & $\mathrm{~N} / \mathrm{A}$ \\
\hline & Specific Conductance & \multicolumn{2}{|c|}{$380-720$} & N/A & \multicolumn{2}{|c|}{$880-930$} & \multicolumn{2}{|c|}{$1400-2370$} & N/A & \multicolumn{2}{|c|}{$760-1720$} & $\mathrm{~N} / \mathrm{A}$ \\
\hline & TOX (ug/l) & \multicolumn{2}{|c|}{$28-140$} & $\mathrm{~N} / \mathrm{A}$ & \multicolumn{2}{|c|}{$7.8-200$} & \multicolumn{2}{|c|}{$85-1500$} & N/A & \multicolumn{2}{|c|}{$63-1100$} & $\mathrm{~N} / \mathrm{A}$ \\
\hline & TOC (mg/l) & \multicolumn{2}{|c|}{$0.84-3.7$} & N/A & \multicolumn{2}{|c|}{$0.99-1.9$} & \multicolumn{2}{|c|}{$1.5-4.2$} & N/A & \multicolumn{2}{|c|}{$1.1-1.5$} & N/A \\
\hline
\end{tabular}

Specific Conductance unit: umhos $/ \mathrm{cm} @ 25^{\circ} \mathrm{C}$

J - Quantitative estimate.

N/A - Not applicable.

U - Not detected. 
TABLE 9 (continued)

Results of Analysis - Groundwater Samples

Main Plateau (Continued) - Contamination Indicator Constituents

\begin{tabular}{|c|c|c|c|c|c|c|c|c|c|c|c|c|c|}
\hline \multirow[t]{2}{*}{ Week } & \multirow{2}{*}{$\begin{array}{r}\text { Constituents } \\
\text { Well } \\
\text { Sample Event } \\
\text { Sample Date } \\
\end{array}$} & \multicolumn{2}{|c|}{ MPW-8 } & \multicolumn{2}{|c|}{ MPW-9 } & \multicolumn{2}{|c|}{ MPW-10 } & \multicolumn{2}{|c|}{ MPW-11 } & \multirow{2}{*}{$\begin{array}{c}\text { MPW-11-1 } \\
\text { Round } 2 \\
\text { N/A } \\
\end{array}$} & \multicolumn{2}{|c|}{ MPW-12 } & \multirow{2}{*}{$\begin{array}{c}\text { MPW-12-1 } \\
\text { Round } 1 \\
\text { N/A } \\
\end{array}$} \\
\hline & & $\begin{array}{c}\text { Round } 1 \\
4 / 28 / 98 \\
\end{array}$ & $\begin{array}{c}\text { Round } 2 \\
9 / 29 / 98 \\
\end{array}$ & $\begin{array}{c}\text { Round } 1 \\
4 / 28 / 98 \\
\end{array}$ & $\begin{array}{r}\text { Round } 2 \\
9 / 30 / 98 \\
\end{array}$ & $\begin{array}{c}\text { Round } 1 \\
4 / 28 / 98 \\
\end{array}$ & $\begin{array}{c}\text { Round } 2 \\
9 / 30 / 98 \\
\end{array}$ & $\begin{array}{c}\text { Round } 1 \\
4 / 28 / 98 \\
\end{array}$ & $\begin{array}{r}\text { Round } 2 \\
9 / 30 / 98 \\
\end{array}$ & & $\begin{array}{c}\text { Round } 1 \\
4 / 28 / 98 \\
\end{array}$ & $\begin{array}{c}\text { Round } 2 \\
9 / 30 / 98 \\
\end{array}$ & \\
\hline \multirow{5}{*}{ Week 1} & $\mathrm{pH}$ (Standard Unit) & 6.93 & 6.98 & 7.46 & 7.48 & 8.79 & 8.66 & 6.86 & 6.82 & N/A & 6.69 & 6.64 & N/A \\
\hline & Specific Conductance & 3030 & 3440 & 740 & 780 & 670 & 750 & 1380 & 1380 & N/A & 5540 & 6680 & N/A \\
\hline & TOX (ug/l) & 200 & 790 & 78 & 56 & 48 & 76 & 63 & 54 & N/A & 190 & 320 & N/A \\
\hline & TOC $(\mathrm{mg} / \mathrm{l})$ & 3.1 & 3.5 & 1.9 & 2.2 & $0.89 \mathrm{~J}$ & 1.3 & 2.5 & 1.9 & N/A & $0.69 \mathrm{~J}$ & 9.8 & N/A \\
\hline & Sample Date & $5 / 5 / 98$ & $10 / 6 / 98$ & $5 / 5 / 98$ & $10 / 6 / 98$ & $5 / 5 / 98$ & $10 / 6 / 98$ & $5 / 5 / 98$ & $10 / 6 / 98$ & $10 / 6 / 98$ & $5 / 5 / 98$ & $10 / 6 / 98$ & N/A \\
\hline \multirow{5}{*}{ Week 2} & $\mathrm{pH}$ (Standard Unit) & 7.15 & 6.70 & 7.48 & 7.26 & 8.92 & 8.91 & 6.88 & 6.67 & 6.67 & 6.89 & 6.62 & N/A \\
\hline & Specific Conductance & 3410 & 1760 & 780 & 760 & 730 & 710 & 1350 & 900 & 900 & 5270 & 4770 & N/A \\
\hline & TOX (ug/l) & 160 & 1600 & 39 & 69 & 40 & 450 & 95 & 110 & 96 & 190 & 1400 & N/A \\
\hline & TOC $(\mathrm{mg} / \mathrm{l})$ & 2.3 & 2.5 & 1.9 & 1.2 & 1.1 & 1.2 & 1.1 & 1.2 & 1.1 & $0.89 \mathrm{~J}$ & 3.0 & N/A \\
\hline & Sample Date & $5 / 12 / 98$ & $10 / 14 / 98$ & $5 / 12 / 98$ & $10 / 14 / 98$ & $5 / 12 / 98$ & $10 / 14 / 98$ & $5 / 12 / 98$ & $10 / 14 / 98$ & N/A & $5 / 12 / 98$ & $10 / 14 / 98$ & $5 / 12 / 98$ \\
\hline \multirow{5}{*}{ Week 3} & $\mathrm{pH}$ (Standard Unit) & 7.31 & 6.54 & 7.48 & 7.52 & 8.83 & 8.80 & 6.83 & 6.67 & N/A & 6.89 & 6.87 & 6.89 \\
\hline & Specific Conductance & 3290 & 3150 & 780 & 770 & 750 & 730 & 1660 & 1460 & N/A & 6300 & 5240 & 6300 \\
\hline & TOX (ug/l) & 150 & 1700 & 60 & 150 & 48 & 380 & 100 & 170 & N/A & 1000 & 1900 & 2000 \\
\hline & TOC (mg/l) & 2.3 & 1.9 & 1.5 & 1.1 & 1.5 & $<1.0$ & $0.93 \mathrm{~J}$ & 1.0 & N/A & $0.82 \mathrm{~J}$ & 1.0 & $0.92 \mathrm{~J}$ \\
\hline & Sample Date & $5 / 19 / 98$ & $10 / 20 / 98$ & $5 / 19 / 98$ & $10 / 20 / 98$ & $5 / 19 / 98$ & $10 / 20 / 98$ & $5 / 19 / 98$ & $10 / 20 / 98$ & N/A & $5 / 19 / 98$ & $10 / 20 / 98$ & N/A \\
\hline \multirow{4}{*}{ Week 4} & $\mathrm{pH}$ (Standard Unit) & 7.37 & 6.59 & 7.53 & 7.54 & 8.90 & 8.65 & 6.88 & 6.66 & N/A & 6.88 & 6.71 & N/A \\
\hline & Specific Conductance & 3150 & 3180 & 790 & 780 & 750 & 740 & 1590 & 1340 & N/A & 5400 & 5040 & N/A \\
\hline & TOX (ug/l) & 660 & 1600 & 44 & 96 & 19 & 200 & 97 & 180 & N/A & 160 & 290 & N/A \\
\hline & TOC (mg/l) & 2.0 & 2.4 & 1.2 & 1.4 & 1.2 & 1.2 & $<1.0$ & $<1.0$ & N/A & $<1.0$ & 2.9 & N/A \\
\hline \multirow{4}{*}{1998 Range } & $\mathrm{pH}$ (Standard Unit) & \multicolumn{2}{|c|}{$6.54-7.37$} & \multicolumn{2}{|c|}{$7.26-7.54$} & \multicolumn{2}{|c|}{$8.65-8.92$} & \multicolumn{2}{|c|}{$6.66-6.88$} & N/A & \multicolumn{2}{|c|}{$6.62-6.89$} & N/A \\
\hline & Specific Conductance & \multicolumn{2}{|c|}{$1760-3440$} & \multicolumn{2}{|c|}{$740-790$} & \multicolumn{2}{|c|}{$670-750$} & \multicolumn{2}{|c|}{$900-1660$} & N/A & \multicolumn{2}{|c|}{$4770-6680$} & N/A \\
\hline & TOX (ug/l) & \multicolumn{2}{|c|}{$150-1700$} & \multicolumn{2}{|c|}{$39-150$} & \multicolumn{2}{|c|}{$19-450$} & \multicolumn{2}{|c|}{$54-180$} & N/A & \multicolumn{2}{|c|}{$160-1900$} & N/A \\
\hline & TOC $(\mathrm{mg} / \mathrm{l})$ & \multicolumn{2}{|c|}{$1.9-3.5$} & & & 0.8 & 1.5 & 0.9 & & N/A & 0.6 & 9.8 & N/A \\
\hline
\end{tabular}

Specific Conductance unit: umhos $/ \mathrm{cm} @ 25^{\circ} \mathrm{C}$

J - Quantitative estimate.

N/A - Not applicable.

$\mathrm{U}$ - Not detected. 
TABLE 10

FETC-PGH 1998 Groundwater Detection Monitoring Program

Results of Analysis - Groundwater Samples

Valley Fill - Contamination Indicator Constituents

\begin{tabular}{|c|c|c|c|c|c|c|c|c|c|c|c|c|c|c|}
\hline \multirow[t]{2}{*}{ Week } & \multirow{2}{*}{$\begin{array}{r}\text { Constituents } \\
\text { Well } \\
\text { Sample Event } \\
\text { Sample Date } \\
\end{array}$} & \multicolumn{2}{|c|}{ VFW-1 } & \multirow{2}{*}{$\begin{array}{c}\text { VFW-1-1 } \\
\text { Round } 1 \\
\text { N/A }\end{array}$} & \multicolumn{2}{|c|}{ VFW-2 } & \multicolumn{2}{|c|}{ VFW-3 } & \multirow{2}{*}{$\begin{array}{c}\text { VFW-3-1 } \\
\text { Round } 1 \\
\text { N/A } \\
\end{array}$} & \multicolumn{2}{|c|}{ VFW-4 } & \multirow{2}{*}{$\begin{array}{c}\text { VFW-4-1 } \\
\text { Round } 2 \\
\text { N/A } \\
\end{array}$} & \multirow{2}{*}{$\begin{array}{r}\text { VFW-5 } \\
\text { Round } 1 \\
4 / 28 / 98 \\
\end{array}$} & \multirow[b]{2}{*}{$\begin{array}{l}\text { Round } 2 \\
9 / 29 / 98 \\
\end{array}$} \\
\hline & & $\begin{array}{c}\text { Round } 1 \\
4 / 28 / 98 \\
\end{array}$ & $\begin{array}{c}\text { Round } 2 \\
9 / 30 / 98 \\
\end{array}$ & & $\begin{array}{r}\text { Round } 1 \\
4 / 28 / 98 \\
\end{array}$ & $\begin{array}{r}\text { Round } 2 \\
\text { 9/29/98 } \\
\end{array}$ & $\begin{array}{c}\text { Round } 1 \\
4 / 28 / 98 \\
\end{array}$ & $\begin{array}{r}\text { Round } 2 \\
9 / 30 / 98 \\
\end{array}$ & & $\begin{array}{r}\text { Round } 1 \\
4 / 28 / 98 \\
\end{array}$ & $\begin{array}{r}\text { Round } 2 \\
\text { 9/29/98 } \\
\end{array}$ & & & \\
\hline \multirow{5}{*}{ Week 1} & pH (Standard Unit) & 8.21 & 7.41 & $\mathrm{~N} / \mathrm{A}$ & 6.95 & 6.70 & 6.85 & 6.61 & N/A & 6.97 & 6.88 & N/A & 7.17 & 6.72 \\
\hline & Specific Conductance & 620 & 1000 & N/A & 1550 & 1940 & 2180 & 2560 & N/A & 570 & 1430 & N/A & 2780 & 2760 \\
\hline & TOX (ug/l) & 46 & 15 & $\mathrm{~N} / \mathrm{A}$ & 100 & 110 & 180 & 740 & $\mathrm{~N} / \mathrm{A}$ & 120 & 190 & N/A & 120 & 170 \\
\hline & TOC (mg/l) & 2.2 & 2.0 & $\mathrm{~N} / \mathrm{A}$ & 1.2 & 2.2 & 1.7 & 2.7 & $\mathrm{~N} / \mathrm{A}$ & 1.4 & 1.8 & N/A & 2.5 & 3.0 \\
\hline & Sample Date & $5 / 5 / 98$ & $10 / 6 / 98$ & $5 / 5 / 98$ & $5 / 5 / 98$ & $10 / 6 / 98$ & $5 / 5 / 98$ & $10 / 6 / 98$ & $\mathrm{~N} / \mathrm{A}$ & $5 / 5 / 98$ & $10 / 6 / 98$ & $10 / 6 / 98$ & $5 / 5 / 98$ & $10 / 6 / 98$ \\
\hline \multirow{5}{*}{ Week 2} & $\mathrm{pH}$ (Standard Unit) & 8.26 & 7.88 & 8.26 & 6.98 & 6.59 & 6.90 & 6.72 & $\mathrm{~N} / \mathrm{A}$ & 7.04 & 6.90 & 6.90 & 7.15 & 6.97 \\
\hline & Specific Conductance & 630 & 870 & 630 & 2060 & 1760 & 2120 & 2440 & N/A & 1710 & 1810 & 1810 & 2660 & 2710 \\
\hline & TOX (ug/l) & 25 & 130 & 30 & 120 & 47 & 170 & 900 & $\mathrm{~N} / \mathrm{A}$ & 110 & 190 & 270 & 150 & 350 \\
\hline & TOC $(\mathrm{mg} / \mathrm{l})$ & 1.6 & 2.6 & 1.5 & 1.1 & 1.9 & 2.2 & 1.6 & N/A & 1.2 & 1.2 & 1.2 & 2.4 & 2.7 \\
\hline & Sample Date & $5 / 12 / 98$ & $10 / 14 / 98$ & $\mathrm{~N} / \mathrm{A}$ & $5 / 12 / 98$ & $10 / 14 / 98$ & $5 / 12 / 98$ & $10 / 14 / 98$ & $\mathrm{~N} / \mathrm{A}$ & $5 / 12 / 98$ & $10 / 14 / 98$ & N/A & $5 / 12 / 98$ & $10 / 14 / 98$ \\
\hline \multirow{5}{*}{ Week 3} & $\mathrm{pH}$ (Standard Unit) & 8.22 & 7.52 & N/A & 6.92 & 6.62 & 6.83 & 6.64 & N/A & 6.98 & 6.66 & N/A & 7.12 & 6.88 \\
\hline & Specific Conductance & 810 & 940 & $\mathrm{~N} / \mathrm{A}$ & 1260 & 1770 & 1940 & 2510 & $\mathrm{~N} / \mathrm{A}$ & 1700 & 1790 & N/A & 2390 & 2830 \\
\hline & TOX (ug/l) & 52 & 89 & N/A & 86 & 47 & 160 & 670 & N/A & 150 & 710 & N/A & 97 & 220 \\
\hline & TOC (mg/l) & 1.7 & 3.6 & $\mathrm{~N} / \mathrm{A}$ & 1.7 & 2.0 & 1.9 & 1.5 & N/A & 1.3 & 1.3 & N/A & 2.8 & 2.7 \\
\hline & Sample Date & $5 / 19 / 98$ & $10 / 20 / 98$ & N/A & $5 / 19 / 98$ & $10 / 20 / 98$ & $5 / 19 / 98$ & $10 / 20 / 98$ & $5 / 19 / 98$ & $5 / 19 / 98$ & $10 / 20 / 98$ & N/A & $5 / 19 / 98$ & $10 / 20 / 98$ \\
\hline \multirow{4}{*}{ Week 4} & $\mathrm{pH}$ (Standard Unit) & 8.16 & 7.84 & $\mathrm{~N} / \mathrm{A}$ & 6.93 & 6.92 & 6.86 & 6.62 & 6.86 & 6.98 & 6.80 & N/A & 7.15 & 6.94 \\
\hline & Specific Conductance & 930 & 1040 & $\mathrm{~N} / \mathrm{A}$ & 1200 & 1810 & 2090 & 2560 & 2090 & 1790 & 1860 & N/A & 2650 & 3030 \\
\hline & TOX (ug/l) & 19 & 63 & $\mathrm{~N} / \mathrm{A}$ & 100 & 58 & 120 & 630 & 120 & 96 & 660 & N/A & 220 & 190 \\
\hline & TOC (mg/l) & 1.7 & 3.2 & $\mathrm{~N} / \mathrm{A}$ & 1.3 & 2.1 & 1.9 & 1.5 & 1.7 & 1.0 & 1.1 & N/A & 2.4 & 2.4 \\
\hline \multirow{4}{*}{1998 Range } & $\mathrm{pH}$ (Standard Unit) & \multicolumn{2}{|c|}{$7.41-8.26$} & $\mathrm{~N} / \mathrm{A}$ & \multicolumn{2}{|c|}{$6.59-6.98$} & \multicolumn{2}{|c|}{$6.61-6.90$} & $\mathrm{~N} / \mathrm{A}$ & \multicolumn{2}{|c|}{$6.66-7.04$} & N/A & \multicolumn{2}{|l|}{$7.41-8.26$} \\
\hline & Specific Conductance & \multicolumn{2}{|c|}{$620-1040$} & $\mathrm{~N} / \mathrm{A}$ & \multicolumn{2}{|c|}{$1200-2060$} & \multicolumn{2}{|c|}{$1940-2560$} & N/A & \multicolumn{2}{|c|}{$570-1860$} & N/A & \multicolumn{2}{|l|}{$620-1040$} \\
\hline & TOX (ug/l) & \multicolumn{2}{|c|}{$15-130$} & N/A & \multicolumn{2}{|c|}{$47-120$} & \multicolumn{2}{|c|}{$120-900$} & N/A & & & N/A & $15-130$ & \\
\hline & TOC $(\mathrm{mg} / \mathrm{l})$ & & 3.6 & N/A & & & & & N/A & & & N/A & $1.6-3.6$ & \\
\hline
\end{tabular}

Specific Conductance unit: umhos $/ \mathrm{cm} @ 25^{\circ} \mathrm{C}$

$\mathrm{J}$ - Quantitative estimate.

N/A - Not applicable.

$\mathrm{U}$ - Not detected. 
TABLE 10 (continued)

Results of Analysis - Groundwater Samples

Valley Fill (Continued) - Contamination Indicator Constituents

\begin{tabular}{|c|c|c|c|c|c|c|c|c|c|c|c|c|c|}
\hline \multirow[t]{2}{*}{ Week } & \multirow{2}{*}{$\begin{array}{r}\text { Constituents } \\
\text { Well } \\
\text { Sample Event } \\
\text { Sample Date } \\
\end{array}$} & \multirow{2}{*}{$\begin{array}{c}\text { VFW-5-1 } \\
\text { Round } 2 \\
\text { N/A } \\
\end{array}$} & \multicolumn{2}{|c|}{ VFW-6 } & \multirow{2}{*}{$\begin{array}{l}\text { VFW-6-1 } \\
\text { Round } 1 \\
4 / 28 / 98 \\
\end{array}$} & \multicolumn{2}{|c|}{ VFW-7 } & \multirow{2}{*}{$\begin{array}{c}\text { VFW-7-1 } \\
\text { Round } 2 \\
9 / 30 / 98 \\
\end{array}$} & \multicolumn{2}{|c|}{ VFW-8 } & \multicolumn{2}{|c|}{ VFW-9 } & \multirow{2}{*}{$\begin{array}{c}\text { VFW-9-1 } \\
\text { Round } 1 \\
\text { N/A } \\
\end{array}$} \\
\hline & & & $\begin{array}{c}\text { Round } 1 \\
4 / 28 / 98 \\
\end{array}$ & $\begin{array}{c}\text { Round } 2 \\
9 / 29 / 98 \\
\end{array}$ & & $\begin{array}{c}\text { Round } 1 \\
4 / 28 / 98 \\
\end{array}$ & $\begin{array}{r}\text { Round } 2 \\
9 / 30 / 98 \\
\end{array}$ & & $\begin{array}{c}\text { Round } 1 \\
4 / 28 / 98 \\
\end{array}$ & $\begin{array}{r}\text { Round } 2 \\
9 / 29 / 98 \\
\end{array}$ & $\begin{array}{c}\text { Round } 1 \\
4 / 29 / 98 \\
\end{array}$ & $\begin{array}{r}\text { Round } 2 \\
9 / 30 / 98 \\
\end{array}$ & \\
\hline \multirow{5}{*}{ Week 1} & $\mathrm{pH}$ (Standard Unit) & N/A & 7.61 & 7.20 & 7.61 & 6.98 & 6.81 & 6.81 & 8.46 & 7.99 & 6.75 & 6.57 & N/A \\
\hline & Specific Conductance & N/A & 2350 & 2930 & 2350 & 3010 & 3000 & 3000 & 990 & 890 & 670 & 1250 & N/A \\
\hline & TOX (ug/l) & N/A & 33 & 110 & 130 & 130 & 880 & 200 & 20 & 140 & 110 & 120 & N/A \\
\hline & TOC $(\mathrm{mg} / \mathrm{l})$ & N/A & 2.6 & 3.1 & 2.6 & 2.2 & 3.1 & 2.9 & 1.6 & 3.0 & 1.8 & 1.5 & N/A \\
\hline & Sample Date & N/A & $5 / 5 / 98$ & $10 / 6 / 98$ & N/A & $5 / 5 / 98$ & $10 / 6 / 98$ & N/A & $5 / 5 / 98$ & Abandoned & $5 / 5 / 98$ & $10 / 6 / 98$ & N/A \\
\hline \multirow{5}{*}{ Week 2} & $\mathrm{pH}$ (Standard Unit) & N/A & 7.89 & 7.24 & N/A & 6.97 & 6.72 & N/A & 8.39 & Abandoned & 6.72 & 6.98 & N/A \\
\hline & Specific Conductance & N/A & 2110 & 2730 & N/A & 3210 & 2580 & N/A & 1170 & Abandoned & 920 & 1220 & N/A \\
\hline & TOX (ug/l) & N/A & 62 & 340 & N/A & 180 & 1500 & N/A & 14 & Abandoned & 54 & 430 & $\mathrm{~N} / \mathrm{A}$ \\
\hline & TOC $(\mathrm{mg} / \mathrm{l})$ & N/A & 2.9 & 3.0 & N/A & 1.9 & 2.4 & N/A & 1.9 & Abandoned & 1.9 & 1.1 & N/A \\
\hline & Sample Date & N/A & $5 / 12 / 98$ & $10 / 14 / 98$ & N/A & $5 / 12 / 98$ & $10 / 14 / 98$ & N/A & $5 / 12 / 98$ & Abandoned & $5 / 12 / 98$ & $10 / 14 / 98$ & $5 / 12 / 98$ \\
\hline \multirow{5}{*}{ Week 3} & $\mathrm{pH}$ (Standard Unit) & N/A & 7.68 & 6.78 & N/A & 7.02 & 6.79 & N/A & 8.38 & Abandoned & 7.12 & 6.64 & 7.12 \\
\hline & Specific Conductance & N/A & 1980 & 2680 & N/A & 3120 & 2920 & N/A & 1160 & Abandoned & 1130 & 1240 & 1130 \\
\hline & TOX (ug/l) & N/A & 110 & 680 & N/A & 160 & 970 & N/A & $8.6 \mathrm{~J}$ & Abandoned & 95 & 630 & 95 \\
\hline & TOC $(\mathrm{mg} / \mathrm{l})$ & N/A & 3.0 & 3.1 & N/A & 2.0 & 2.2 & N/A & 1.9 & Abandoned & 1.7 & 1.3 & 1.6 \\
\hline & Sample Date & $10 / 20 / 98$ & $5 / 19 / 98$ & $10 / 20 / 98$ & N/A & $5 / 19 / 98$ & $10 / 20 / 98$ & N/A & $5 / 19 / 98$ & Abandoned & $5 / 19 / 98$ & $10 / 20 / 98$ & N/A \\
\hline \multirow{4}{*}{ Week 4} & $\mathrm{pH}$ (Standard Unit) & 6.94 & 7.18 & 7.10 & N/A & 6.94 & 6.79 & N/A & 8.46 & Abandoned & 7.19 & 7.09 & N/A \\
\hline & Specific Conductance & 3030 & 2180 & 2850 & N/A & 2920 & 3080 & N/A & 1290 & Abandoned & 1020 & 1300 & N/A \\
\hline & TOX (ug/l) & 330 & 110 & 360 & N/A & 130 & 940 & $\mathrm{~N} / \mathrm{A}$ & $<10$ & Abandoned & 77 & 610 & N/A \\
\hline & TOC (mg/l) & 2.4 & 2.8 & 2.7 & N/A & 2.0 & 2.4 & N/A & 1.4 & Abandoned & 1.2 & 1.4 & N/A \\
\hline \multirow{4}{*}{1998 Range } & $\mathrm{pH}$ (Standard Unit) & N/A & \multicolumn{2}{|c|}{$6.78-7.89$} & N/A & \multicolumn{2}{|c|}{$6.72-7.02$} & $\mathrm{~N} / \mathrm{A}$ & \multicolumn{2}{|c|}{$7.99-8.46$} & \multicolumn{2}{|c|}{$6.57-7.19$} & N/A \\
\hline & Specific Conductance & N/A & \multicolumn{2}{|c|}{$1980-2930$} & N/A & \multicolumn{2}{|c|}{$2580-3210$} & N/A & \multicolumn{2}{|c|}{$890-1290$} & \multicolumn{2}{|c|}{$670-1300$} & N/A \\
\hline & TOX (ug/l) & N/A & \multicolumn{2}{|c|}{$33-680$} & N/A & \multicolumn{2}{|c|}{$130-1500$} & $\mathrm{~N} / \mathrm{A}$ & \multicolumn{2}{|c|}{$8.6-140$} & \multicolumn{2}{|c|}{$54-630$} & N/A \\
\hline & TOC (mg/l) & N/A & \multicolumn{2}{|c|}{$2.6-3.1$} & N/A & \multicolumn{2}{|c|}{$1.9-3.1$} & N/A & \multicolumn{2}{|c|}{$1.4-3.0$} & & & N/A \\
\hline
\end{tabular}

Specific Conductance unit: umhos $/ \mathrm{cm} @ 25^{\circ} \mathrm{C}$

$\mathrm{U}$ - Not detected. 
TABLE 10 (continued)

Results of Analysis - Groundwater Samples

Valley Fill (Continued) - Contamination Indicator Constituents

\begin{tabular}{|c|c|c|c|c|c|c|c|c|c|c|c|c|c|c|}
\hline \multirow[t]{2}{*}{ Week } & \multirow{2}{*}{$\begin{array}{r}\text { Constituents } \\
\text { Well } \\
\text { Sample Event } \\
\text { Sample Date } \\
\end{array}$} & \multicolumn{2}{|c|}{ VFW-10 } & \multirow{2}{*}{$\begin{array}{c}\text { VFW-10-1 } \\
\text { Round } 2 \\
\text { N/A } \\
\end{array}$} & \multicolumn{2}{|c|}{ VFW-11 } & \multicolumn{2}{|c|}{ VFW-11D } & \multicolumn{2}{|c|}{ VFW-12 } & \multicolumn{2}{|c|}{ VFW-13 } & \multicolumn{2}{|c|}{ VFW-14 } \\
\hline & & $\begin{array}{r}\text { Round } 1 \\
4 / 29 / 98 \\
\end{array}$ & $\begin{array}{r}\text { Round } 2 \\
9 / 30 / 98 \\
\end{array}$ & & $\begin{array}{l}\text { Round } 1 \\
4 / 29 / 98 \\
\end{array}$ & $\begin{array}{r}\text { Round } 2 \\
9 / 29 / 98 \\
\end{array}$ & $\begin{array}{c}\text { Round } 1 \\
4 / 29 / 98 \\
\end{array}$ & $\begin{array}{r}\text { Round } 2 \\
9 / 29 / 98 \\
\end{array}$ & $\begin{array}{c}\text { Round } 1 \\
4 / 29 / 98 \\
\end{array}$ & $\begin{array}{r}\text { Round } 2 \\
9 / 29 / 98 \\
\end{array}$ & $\begin{array}{r}\text { Round } 1 \\
4 / 28 / 98 \\
\end{array}$ & $\begin{array}{r}\text { Round } 2 \\
9 / 30 / 98 \\
\end{array}$ & $\begin{array}{c}\text { Round } 1 \\
4 / 28 / 98 \\
\end{array}$ & $\begin{array}{r}\text { Round } 2 \\
9 / 30 / 98 \\
\end{array}$ \\
\hline \multirow{5}{*}{ Week 1} & $\mathrm{pH}$ (Standard Unit) & 6.84 & 6.82 & N/A & 7.17 & 7.16 & 8.42 & 8.38 & 7.11 & 7.16 & 6.96 & 8.29 & 6.87 & 6.73 \\
\hline & Specific Conductance & 1780 & 1930 & N/A & 1460 & 1340 & 1760 & 1680 & 1800 & 1790 & 1060 & 1050 & 2860 & 2590 \\
\hline & TOX (ug/l) & 41 & 22 & N/A & $7.6 \mathrm{~J}$ & 140 & 13 & 79 & 150 & 190 & 79 & 69 & 140 & 150 \\
\hline & TOC $(\mathrm{mg} / \mathrm{l})$ & 2.4 & 3.5 & N/A & $0.92 \mathrm{~J}$ & 1.6 & 2.2 & 3.0 & 2.8 & 2.6 & 1.3 & 1.5 & 2.3 & 2.1 \\
\hline & Sample Date & $5 / 5 / 98$ & $10 / 6 / 98$ & N/A & $5 / 5 / 98$ & $10 / 6 / 98$ & $5 / 5 / 98$ & Abandoned & $5 / 5 / 98$ & $10 / 6 / 98$ & $5 / 5 / 98$ & $10 / 6 / 98$ & $5 / 5 / 98$ & $10 / 6 / 98$ \\
\hline \multirow{5}{*}{ Week 2} & $\mathrm{pH}$ (Standard Unit) & 6.94 & 6.77 & N/A & 7.14 & 6.91 & 8.28 & Abandoned & 7.05 & 7.10 & 6.96 & Abandoned & 6.96 & 6.80 \\
\hline & Specific Conductance & 1720 & 1690 & N/A & 1450 & 1360 & 1760 & Abandoned & 1890 & 1860 & 1090 & Abandoned & 2700 & 2560 \\
\hline & TOX (ug/l) & 37 & 61 & N/A & 140 & 260 & 24 & Abandoned & 150 & 240 & 85 & Abandoned & 190 & 120 \\
\hline & TOC $(\mathrm{mg} / \mathrm{l})$ & 1.6 & 1.9 & N/A & 1.7 & $<1.0$ & 3.4 & Abandoned & 2.4 & 2.1 & 1.0 & Abandoned & 2.1 & 1.7 \\
\hline & Sample Date & $5 / 12 / 98$ & $10 / 14 / 98$ & $10 / 14 / 98$ & $5 / 12 / 98$ & $10 / 15 / 97$ & $5 / 12 / 98$ & Abandoned & $5 / 12 / 98$ & $10 / 15 / 97$ & $5 / 12 / 98$ & Abandoned & $5 / 12 / 98$ & $10 / 15 / 97$ \\
\hline \multirow{5}{*}{ Week 3} & $\mathrm{pH}$ (Standard Unit) & 6.87 & 6.69 & 6.69 & 7.18 & 6.82 & 8.26 & Abandoned & 7.10 & 6.87 & 7.91 & Abandoned & 6.84 & 6.72 \\
\hline & Specific Conductance & 1750 & 1770 & 1770 & 1420 & 1340 & 1760 & Abandoned & 1650 & 1860 & 1090 & Abandoned & 2630 & 2610 \\
\hline & TOX (ug/l) & 23 & 130 & 74 & 170 & 320 & 59 & Abandoned & 140 & 200 & 87 & Abandoned & 150 & 200 \\
\hline & TOC $(\mathrm{mg} / \mathrm{l})$ & 1.7 & 2.1 & 1.8 & $0.92 \mathrm{~J}$ & $<1.0$ & 3.6 & Abandoned & 2.4 & 2.5 & 1.1 & Abandoned & 1.9 & 1.9 \\
\hline & Sample Date & $5 / 19 / 98$ & $10 / 20 / 98$ & N/A & $5 / 19 / 98$ & $10 / 20 / 98$ & $5 / 19 / 98$ & Abandoned & $5 / 19 / 98$ & $10 / 20 / 98$ & $5 / 19 / 98$ & Abandoned & $5 / 19 / 98$ & $10 / 20 / 98$ \\
\hline \multirow{4}{*}{ Week 4} & $\mathrm{pH}$ (Standard Unit) & 6.85 & 6.81 & N/A & 7.15 & 6.95 & 8.26 & Abandoned & 7.15 & 7.08 & 8.16 & Abandoned & 6.87 & 6.75 \\
\hline & Specific Conductance & 1800 & 1930 & N/A & 1270 & 1390 & 1760 & Abandoned & 1750 & 1930 & 1020 & Abandoned & 2650 & 2670 \\
\hline & TOX (ug/l) & 66 & 54 & N/A & 120 & 260 & 40 & Abandoned & 81 & 240 & 57 & Abandoned & 160 & 210 \\
\hline & TOC (mg/l) & 2.1 & 1.9 & N/A & $<1.0$ & $<1.0$ & 3.5 & Abandoned & 1.9 & 2.4 & $<1.0$ & Abandoned & 1.7 & 1.8 \\
\hline \multirow{4}{*}{1998 Range } & $\mathrm{pH}$ (Standard Unit) & \multicolumn{2}{|l|}{$6.69-6.94$} & N/A & \multicolumn{2}{|c|}{$6.82-7.18$} & \multicolumn{2}{|c|}{$8.26-8.42$} & \multicolumn{2}{|c|}{$6.87-7.16$} & \multicolumn{2}{|c|}{$6.96-8.29$} & \multicolumn{2}{|c|}{$6.72-6.96$} \\
\hline & Specific Conductance & \multicolumn{2}{|c|}{$1690-1930$} & N/A & \multicolumn{2}{|c|}{$1270-1460$} & \multicolumn{2}{|c|}{$1680-1760$} & \multicolumn{2}{|c|}{$1650-1930$} & \multicolumn{2}{|c|}{$1020-1090$} & \multicolumn{2}{|c|}{$2560-2860$} \\
\hline & TOX (ug/l) & \multicolumn{2}{|l|}{$22-130$} & N/A & \multicolumn{2}{|c|}{$7.6-320$} & \multicolumn{2}{|c|}{$13-79$} & & & & -87 & 120 & 210 \\
\hline & TOC (mg/l) & $1.6-3.5$ & & N/A & 0.92 & 1.7 & & -3.6 & & & $<1$. & -1.5 & & 2.3 \\
\hline
\end{tabular}

Specific Conductance unit: umhos $/ \mathrm{cm} @ 25^{\circ \mathrm{C}}$

$\mathrm{J}$ - Quantitative estimate.

N/A - Not applicable.

$\mathrm{U}$ - Not detected. 
TABLE 11

FETC-PGH 1998 Groundwater Detection Monitoring Program

Results of Analysis - Groundwater Samples

Main Plateau - Groundwater Characteristics Constituents

\begin{tabular}{|c|c|c|c|c|c|c|c|c|c|c|c|c|}
\hline \multirow{3}{*}{ Constituent } & \multicolumn{12}{|c|}{ Well Number and Sample Date } \\
\hline & \multicolumn{2}{|c|}{ MPW-1 } & \multicolumn{2}{|c|}{ MPW-2 } & \multirow{2}{*}{$\begin{array}{c}\text { MPW-2-1 } \\
4 / 28 / 98\end{array}$} & \multicolumn{2}{|c|}{ MPW-3 } & \multicolumn{2}{|c|}{ MPW-4 } & \multirow{2}{*}{$\begin{array}{c}\text { MPW-4-1 } \\
4 / 29 / 98\end{array}$} & \multicolumn{2}{|c|}{ MPW-4D } \\
\hline & $4 / 28 / 98$ & 9/30/98 & $4 / 28 / 98$ & $9 / 29 / 98$ & & $4 / 28 / 98$ & 9/29-30/98 & $4 / 29 / 98$ & $9 / 30 / 98$ & & $4 / 29 / 98$ & $9 / 30 / 98$ \\
\hline \multicolumn{13}{|l|}{ Inorganics (ug/l) } \\
\hline Aluminum & $50 \mathrm{U}$ & $50 \mathrm{U}$ & $50 \mathrm{U}$ & $50 \mathrm{U}$ & N/A & 3500 & 2700 & $50 \mathrm{U}$ & $50 \mathrm{U}$ & $50 \mathrm{U}$ & 210 & 110 \\
\hline Boron & 120 & 27 & 610 & 33 & N/A & 2100 & 370 & 77 & 37 & 82 & 200 & 100 \\
\hline Calcium & 360000 & 280000 & 310000 & 2700 & N/A & 8400 & 88000 & 300000 & 280000 & 290000 & 5500 & 8900 \\
\hline Iron & 110 & 53 & 140 & 730 & N/A & 2000 & $30 \mathrm{U}$ & 88 & 56 & 68 & 230 & 110 \\
\hline Magnesium & 200000 & 190000 & 78000 & 68000 & N/A & 2200 & 960 & 120000 & 86000 & 110000 & 1200 & 3400 \\
\hline Manganese & 59 & 230 & 1600 & 1300 & N/A & 83 & 9.0 & 130 & 100 & 150 & 13 & 13 \\
\hline Nickel & 300 & 840 & $10 \mathrm{U}$ & 24 & N/A & 16 & $10 \mathrm{U}$ & 1000 & 380 & 1000 & $10 \mathrm{U}$ & 19 \\
\hline Phosphorus & $50 \mathrm{U}$ & NS & $50 \mathrm{U}$ & NS & N/A & $50 \mathrm{U}$ & NS & $50 \mathrm{U}$ & NS & $50 \mathrm{U}$ & $50 \mathrm{U}$ & NS \\
\hline Potassium & 6000 & 3900 & 4100 & 2300 & N/A & 9100 & 2300 & 4100 & 3500 & 3800 & 1300 & 780 \\
\hline Silicon & 2900 & 2400 & 3200 & 2900 & N/A & 6600 & 5800 & 3100 & 1900 & 2900 & 3400 & 2000 \\
\hline Sodium & 78000 & 52000 & 180000 & 390000 & N/A & 370000 & 8700 & 140000 & 85000 & 140000 & 380000 & 150000 \\
\hline Strontium & 1400 & 790 & 630 & 380 & N/A & 210 & 110 & 1100 & 880 & 1100 & 140 & 120 \\
\hline \multicolumn{13}{|c|}{\begin{tabular}{|l} 
Quality Parameters $(\mathrm{mg} / \mathrm{l})$ \\
\end{tabular}} \\
\hline Chloride & 1000 & 1000 & 800 & 640 & N/A & 47 & 46 & 310 & 510 & N/A & 91 & 92 \\
\hline Fluoride & 0.14 & $0.00 \mathrm{~B}$ & $0.00 \mathrm{~B}$ & $0.10 \mathrm{U}$ & N/A & 4.6 & 4.0 & 0.19 & 2.1 & $\mathrm{~N} / \mathrm{A}$ & 1.7 & 1.4 \\
\hline Nitrate & $0.055 \mathrm{~B}$ & 0.47 & 0.49 & 0.73 & 0.49 & 0.47 & 19 & 0.11 & 0.32 & N/A & $0.016 \mathrm{~B}$ & 0.47 \\
\hline Sulfate & 130 & 120 & 140 & 73 & N/A & 130 & 28 & 140 & 77 & N/A & 20 & 3.9 \\
\hline \begin{tabular}{|l} 
Total Dissolved Solids \\
\end{tabular} & 2080 & $\mathrm{NS}$ & 1600 & $\mathrm{NS}$ & N/A & 1040 & $\mathrm{NS}$ & 1430 & NS & $\mathrm{N} / \mathrm{A}$ & 463 & $\mathrm{NS}$ \\
\hline Total Alkalinity & 183 & 207 & 156 & 182 & N/A & 658 & 748 & 214 & 235 & N/A & 306 & 222 \\
\hline
\end{tabular}

$B$ - Less than five times in the associated blank.

N/A - Not applicable.

NS - Not sampled.

$\mathrm{U}$ - Not detected. 
TABLE 11 (continued)

Results of Analysis - Groundwater Samples

Main Plateau (Continued) - Groundwater Characteristics Constituents

\begin{tabular}{|c|c|c|c|c|c|c|c|c|c|c|c|c|}
\hline \multirow{3}{*}{ Constituent } & \multicolumn{12}{|c|}{ Well Number and Sample Date } \\
\hline & \multicolumn{2}{|c|}{ MPW-6 } & \multicolumn{2}{|c|}{ MPW-6D } & \multirow{2}{*}{$\begin{array}{c}\text { MPW-6D-1 } \\
\text { 9/29/98 }\end{array}$} & \multicolumn{2}{|c|}{ MPW-7 } & \multicolumn{2}{|c|}{ MPW-7D } & \multirow{2}{*}{$\begin{array}{l}\text { MPW-7D -1 } \\
4 / 29-9 / 29 / 98\end{array}$} & \multicolumn{2}{|c|}{ MPW-8 } \\
\hline & $4 / 29 / 98$ & $9 / 29 / 98$ & $4 / 29 / 98$ & $9 / 29 / 98$ & & $4 / 29 / 98$ & 9/29-30/98 & $4 / 29 / 98$ & $9 / 29 / 98$ & & $4 / 28-5 / 12 / 98$ & 9/29-30/98 \\
\hline \multicolumn{13}{|l|}{ Inorganics (ug/l) } \\
\hline Aluminum & $50 \mathrm{U}$ & $50 \mathrm{U}$ & 290 & 460 & N/A & $50 \mathrm{U}$ & $50 \mathrm{U}$ & 230 & $50 \mathrm{U}$ & N/A & $50 \mathrm{U}$ & 340 \\
\hline Boron & 95 & 85 & 290 & 260 & N/A & 140 & 50 & 78 & 84 & N/A & 84 & 67 \\
\hline Calcium & 99000 & 97000 & 1600 & 1700 & N/A & 230000 & 210000 & 190000 & 260000 & N/A & 350000 & 270000 \\
\hline Iron & $30 \mathrm{U}$ & 200 & 170 & 42 & N/A & 86 & 1700 & 800 & 370 & N/A & 630 & 2100 \\
\hline Magnesium & 40000 & 38000 & 420 & 720 & N/A & 31000 & 38000 & 40000 & 39000 & N/A & 81000 & 59000 \\
\hline Manganese & 52 & 31 & 5.0 & 10 & N/A & 120 & 930 & 93 & 61 & N/A & 1300 & 840 \\
\hline Nickel & $10 \mathrm{U}$ & $10 \mathrm{U}$ & $10 \mathrm{U}$ & $10 \mathrm{U}$ & N/A & 590 & $10 \mathrm{U}$ & 180 & 150 & N/A & 140 & 870 \\
\hline Phosphorus & $50 \mathrm{U}$ & NS & $50 \mathrm{U}$ & NS & N/A & $50 \mathrm{U}$ & NS & $50 \mathrm{U}$ & NS & N/A & $50 \mathrm{U}$ & NS \\
\hline Potassium & 2400 & 660 & 680 & 2100 & N/A & 5100 & 4100 & 3100 & 4200 & N/A & 7200 & 3800 \\
\hline Silicon & 4600 & 4100 & 3100 & 2800 & N/A & 3300 & 2800 & 3400 & 3100 & N/A & 14000 & 3300 \\
\hline Sodium & 10000 & 8700 & 470000 & 420000 & N/A & 290000 & 250000 & 150000 & 130000 & N/A & 220000 & 150000 \\
\hline Strontium & 2000 & 1800 & 43 & 590 & N/A & 340 & 1000 & 1100 & 1300 & N/A & 810 & 490 \\
\hline \multicolumn{13}{|c|}{ Quality Parameters (mg/l) } \\
\hline Chloride & 58 & 82 & 44 & 42 & 42 & 410 & 630 & 330 & 280 & 320 & 910 & 850 \\
\hline Fluoride & $0.00 \mathrm{~B}$ & $0.10 \mathrm{U}$ & 2.2 & 2.1 & 2.2 & 0.33 & 0.17 & $0.00 \mathrm{~B}$ & 0.11 & $0.00 \mathrm{~B}$ & 0.11 & 0.11 \\
\hline Nitrate & 0.43 & 0.93 & $0.017 \mathrm{~B}$ & 0.22 & NS & 2.3 & 1.0 & 0.14 & 0.44 & 0.42 & 0.16 & 0.51 \\
\hline Sulfate & 31 & 6.0 & 6.2 & 4.7 & 5.0 & 160 & 73 & 100 & 93 & 98 & 150 & 130 \\
\hline Total Dissolved Solids & 354 & NS & 452 & NS & $\mathrm{NS}$ & 1090 & $\mathrm{NS}$ & 933 & $\mathrm{NS}$ & 1010 & 2340 & NS \\
\hline Total Alkalinity & 251 & 269 & 475 & 517 & 505 & 136 & 322 & 189 & 243 & 183 & 218 & 244 \\
\hline
\end{tabular}

B - Less than five times in the associated blank.

N/A - Not applicable.

NS - Not sampled.

$\mathrm{U}$ - Not detected. 
TABLE 11 (continued)

Results of Analysis - Groundwater Samples

Main Plateau (Continued) - Groundwater Characteristics Constituents

\begin{tabular}{|c|c|c|c|c|c|c|c|c|c|}
\hline \multirow{3}{*}{ Constituent } & \multicolumn{9}{|c|}{ Well Number and Sample Date } \\
\hline & \multicolumn{2}{|c|}{ MPW-9 } & \multicolumn{2}{|c|}{ MPW-10 } & \multirow{2}{*}{$\begin{array}{c}\text { MPW-10-1 } \\
9 / 30 / 98 \\
\end{array}$} & \multicolumn{2}{|c|}{ MPW-11 } & \multicolumn{2}{|c|}{ MPW-12 } \\
\hline & $4 / 28 / 98$ & $9 / 30 / 98$ & $4 / 28 / 98$ & $9 / 30 / 98$ & & $4 / 28 / 98$ & 9/30/98 & $4 / 28 / 98$ & 9/30/98 \\
\hline \multicolumn{10}{|l|}{ Inorganics (ug/l) } \\
\hline Aluminum & $50 \mathrm{U}$ & $50 \mathrm{U}$ & 92 & 180 & 310 & $50 \mathrm{U}$ & $50 \mathrm{U}$ & 59 & $50 \mathrm{U}$ \\
\hline Boron & 160 & 58 & 150 & 74 & 59 & 100 & 78 & 62 & $10 \mathrm{U}$ \\
\hline Calcium & 75000 & 55000 & 4100 & 2200 & 2900 & 140000 & 90000 & 680000 & 600000 \\
\hline Iron & 270 & 53 & 150 & 93 & 140 & 120 & 90 & 54 & $30 \mathrm{U}$ \\
\hline Magnesium & 18000 & 12000 & 780 & 310 & 420 & 39000 & 18000 & 53000 & $200 \mathrm{U}$ \\
\hline Manganese & 200 & 50 & 19 & 8.0 & 15 & 370 & 69 & 52 & $5.0 \mathrm{U}$ \\
\hline Nickel & 93 & 60 & $10 \mathrm{U}$ & $10 \mathrm{U}$ & $10 \mathrm{U}$ & 180 & 62 & 49 & $10 \mathrm{U}$ \\
\hline Phosphorus & $50 \mathrm{U}$ & NS & $50 \mathrm{U}$ & NS & NS & $50 \mathrm{U}$ & NS & $50 \mathrm{U}$ & NS \\
\hline Potassium & 1600 & 940 & 720 & 610 & 630 & 3800 & 1800 & 6600 & 4900 \\
\hline Silicon & 2800 & 2200 & 3200 & 2200 & 2300 & 2600 & 1700 & 3100 & 1200 \\
\hline Sodium & 89000 & 61000 & 210000 & 130000 & 110000 & 110000 & 55000 & 1000000 & 810000 \\
\hline Strontium & 1400 & 840 & 74 & 57 & 45 & 360 & 140 & 780 & 490 \\
\hline \multicolumn{10}{|c|}{ Quality Parameters (mg/l) } \\
\hline Chloride & 97 & 78 & 56 & 53 & N/A & 280 & 130 & 2700 & 2400 \\
\hline Fluoride & 0.15 & 0.12 & 0.53 & 0.39 & $\mathrm{~N} / \mathrm{A}$ & 0.22 & 0.25 & $0.00 \mathrm{~B}$ & $0.00 \mathrm{~B}$ \\
\hline Nitrate & $0.085 \mathrm{~B}$ & 0.52 & $0.050 \mathrm{~B}$ & 0.24 & $\mathrm{~N} / \mathrm{A}$ & 1.6 & 1.9 & 1.3 & 1.3 \\
\hline Sulfate & 56 & 34 & 21 & 5.9 & N/A & 160 & 97 & 160 & 110 \\
\hline Total Dissolved Solids & 446 & NS & 376 & NS & N/A & 1060 & NS & 4870 & NS \\
\hline Total Alkalinity & 197 & 245 & 296 & 313 & $\mathrm{~N} / \mathrm{A}$ & 121 & 123 & 130 & 268 \\
\hline
\end{tabular}

B - Less than five times in the associated blank.

N/A - Not applicable.

NS - Not sampled.

$\mathrm{U}$ - Not detected. 
TABLE 12

FETC-PGH 1998 Groundwater Detection Monitoring Program

Results of Analysis - Groundwater Samples

Valley Fill - Groundwater Characteristics Constituents

\begin{tabular}{|c|c|c|c|c|c|c|c|c|c|c|c|c|}
\hline \multirow{3}{*}{ Constituent } & \multicolumn{12}{|c|}{ Well Number and Sample Date } \\
\hline & \multicolumn{2}{|c|}{ VFW-1 } & \multirow{2}{*}{$\begin{array}{c}\text { VFW-1-1 } \\
9 / 30 / 98\end{array}$} & \multicolumn{2}{|c|}{ VFW-2 } & \multicolumn{2}{|c|}{ VFW-3 } & \multicolumn{2}{|c|}{ VFW-4 } & \multicolumn{2}{|c|}{ VFW-5 } & \multirow{2}{*}{$\begin{array}{c}\text { VFW-5-1 } \\
9 / 29 / 98\end{array}$} \\
\hline & $4 / 28 / 98$ & $9 / 30 / 98$ & & $4 / 28 / 98$ & $9 / 29 / 98$ & $4 / 28 / 98$ & $9 / 30 / 98$ & $4 / 28 / 98$ & $9 / 29 / 98$ & $4 / 28 / 98$ & $9 / 29 / 98$ & \\
\hline \multicolumn{13}{|l|}{ Inorganics (ug/l) } \\
\hline Aluminum & 180 & 170 & $\mathrm{~N} / \mathrm{A}$ & $50 \mathrm{U}$ & $50 \mathrm{U}$ & $50 \mathrm{U}$ & $50 \mathrm{U}$ & $50 \mathrm{U}$ & $50 \mathrm{U}$ & $50 \mathrm{U}$ & $50 \mathrm{U}$ & N/A \\
\hline Boron & 300 & 220 & $\mathrm{~N} / \mathrm{A}$ & 160 & 190 & 65 & 67 & 64 & 49 & 260 & 280 & N/A \\
\hline Calcium & 7300 & 10000 & $\mathrm{~N} / \mathrm{A}$ & 290000 & 230000 & 210000 & 280000 & 220000 & 230000 & 220000 & 310000 & $\mathrm{~N} / \mathrm{A}$ \\
\hline Iron & 44 & 92 & $\mathrm{~N} / \mathrm{A}$ & 140 & 49 & 240 & 75 & $30 \mathrm{U}$ & 35 & 92 & 310 & N/A \\
\hline Magnesium & 1700 & 2200 & N/A & 63000 & 58000 & 86000 & 140000 & 71000 & 79000 & 30000 & 32000 & N/A \\
\hline Manganese & 13 & 17 & N/A & 2000 & 2100 & 100 & 900 & 120 & 110 & $5 \mathrm{U}$ & 6.0 & N/A \\
\hline Nickel & $10 \mathrm{U}$ & 11 & N/A & $10 \mathrm{U}$ & $10 \mathrm{U}$ & 350 & 340 & 120 & 110 & $10 \mathrm{U}$ & $10 \mathrm{U}$ & N/A \\
\hline Phosphorus & $50 \mathrm{U}$ & NS & N/A & $50 \mathrm{U}$ & $\mathrm{NS}$ & $50 \mathrm{U}$ & NS & $50 \mathrm{U}$ & NS & $50 \mathrm{U}$ & NS & N/A \\
\hline Potassium & 1400 & 1500 & N/A & 5400 & 3700 & 5600 & 5400 & 4000 & 4400 & 7200 & 10000 & N/A \\
\hline Silicon & 3400 & 2700 & N/A & 6400 & 6800 & 3400 & 5100 & 4400 & 3800 & 7300 & 3600 & N/A \\
\hline Sodium & 290000 & 240000 & N/A & 150000 & 200000 & 100000 & 110000 & 21000 & 29000 & 730000 & 240000 & N/A \\
\hline Strontium & 320 & 340 & N/A & 2400 & 1600 & 900 & 900 & 1500 & 1200 & 470 & 400 & N/A \\
\hline Chloride & 18 & 23 & N/A & 290 & 79 & 470 & 550 & 360 & 360 & 650 & 580 & 580 \\
\hline Fluoride & 1.6 & 1.4 & N/A & 1.4 & 1.7 & 0.21 & 0.18 & 0.23 & 0.21 & 1.1 & 0.87 & 0.89 \\
\hline Nitrate & $0.054 \mathrm{~B}$ & 0.33 & $0.045 \mathrm{~B}$ & $0.026 \mathrm{~B}$ & 0.27 & 1.7 & 1.2 & 0.12 & 0.36 & 0.72 & 0.92 & $\mathrm{NS}$ \\
\hline Sulfate & 6.4 & $1.0 \mathrm{U}$ & N/A & 640 & 530 & 110 & 100 & 49 & 50 & 270 & 200 & 240 \\
\hline Total Dissolved Solids & 429 & $\mathrm{NS}$ & N/A & 1360 & $\mathrm{NS}$ & 1380 & $\mathrm{NS}$ & 1000 & $\mathrm{NS}$ & 1520 & NS & NS \\
\hline Total Alkalinity & 507 & 542 & N/A & 179 & 214 & 273 & 319 & 291 & 297 & 188 & 249 & 239 \\
\hline
\end{tabular}

$B$ - Less than five times in the associated blank.

N/A - Not applicable.

NS - Not sampled.

U - Not detected. 
TABLE 12 (continued)

Results of Analysis - Groundwater Samples

Valley Fill (Continued) - Groundwater Characteristics Constituents

\begin{tabular}{|c|c|c|c|c|c|c|c|c|c|c|c|c|c|}
\hline \multirow[t]{2}{*}{ Constituent } & \multicolumn{2}{|c|}{ VFW-6 } & \multirow{2}{*}{$\begin{array}{c}\text { VFW-6-1 } \\
\text { 9/29/98 }\end{array}$} & \multicolumn{2}{|c|}{ VFW-7 } & \multirow{2}{*}{$\begin{array}{c}\text { VFW-7-1 } \\
4 / 28 / 98 \\
\end{array}$} & \multicolumn{2}{|c|}{ VFW-8 } & \multicolumn{2}{|c|}{ VFW-9 } & \multicolumn{2}{|c|}{ VFW-10 } & \multirow{2}{*}{$\begin{array}{c}\text { VFW-10-1 } \\
4 / 29 / 98 \\
\end{array}$} \\
\hline & 4/28/98 & $9 / 29 / 98$ & & $4 / 28 / 98$ & $9 / 30 / 98$ & & $4 / 28-29 / 98$ & 9/29-30/98 & $4 / 29 / 98$ & 9/30/98 & $4 / 29 / 98$ & 9/30/98 & \\
\hline \multicolumn{14}{|l|}{ Inorganics (ug/l) } \\
\hline Aluminum & $50 \mathrm{U}$ & $50 \mathrm{U}$ & $50 \mathrm{U}$ & $50 \mathrm{U}$ & $50 \mathrm{U}$ & $\mathrm{N} / \mathrm{A}$ & 1400 & 180 & $50 \mathrm{U}$ & $50 \mathrm{U}$ & $50 \mathrm{U}$ & $50 \mathrm{U}$ & 100 \\
\hline Boron & 130 & 230 & 230 & 59 & 48 & N/A & 1800 & 220 & 30 & 53 & 110 & 130 & 63 \\
\hline Calcium & 230000 & 310000 & 4000 & 29000 & 310000 & N/A & 4500 & 180000 & 120000 & 170000 & 330000 & 170000 & 340000 \\
\hline Iron & 100 & 370 & 170 & 860 & 450 & N/A & 850 & 100 & 120 & 67 & $30 \mathrm{U}$ & 70 & $30 \mathrm{U}$ \\
\hline Magnesium & 41000 & 55000 & 56000 & 63000 & 38000 & $\mathrm{~N} / \mathrm{A}$ & 700 & 450 & 33000 & 31000 & 77000 & 32000 & 78000 \\
\hline Manganese & 510 & 810 & 910 & 1200 & 910 & N/A & 14 & 10 & 21 & 19 & 2400 & 490 & 2100 \\
\hline Nickel & $10 \mathrm{U}$ & $10 \mathrm{U}$ & $10 \mathrm{U}$ & $10 \mathrm{U}$ & $10 \mathrm{U}$ & $\mathrm{N} / \mathrm{A}$ & $10 \mathrm{U}$ & $10 \mathrm{U}$ & 77 & 160 & 13 & $10 \mathrm{U}$ & 14 \\
\hline Phosphorus & $50 \mathrm{U}$ & NS & NS & $50 \mathrm{U}$ & NS & N/A & $50 \mathrm{U}$ & NS & $50 \mathrm{U}$ & NS & $50 \mathrm{U}$ & NS & $50 \mathrm{U}$ \\
\hline Potassium & 11000 & 10000 & 1400 & 8300 & 5600 & $\mathrm{~N} / \mathrm{A}$ & 8900 & 1500 & 3000 & 3100 & 7100 & 7400 & 7700 \\
\hline Silicon & 3700 & 6100 & 6200 & 3600 & 3500 & $\mathrm{~N} / \mathrm{A}$ & 2100 & 1000 & 2900 & 2400 & 5200 & 3800 & 5200 \\
\hline Sodium & 430000 & 240000 & 260000 & 690000 & 220000 & $\mathrm{~N} / \mathrm{A}$ & 480000 & 19000 & 110000 & 44000 & 98000 & 85000 & 110000 \\
\hline Strontium & 780 & 900 & 940 & 1700 & 350 & N/A & 160 & 72 & 200 & 220 & 510 & 230 & 520 \\
\hline \multicolumn{14}{|c|}{ Quality Parameters (mg/l) } \\
\hline Chloride & 430 & 520 & $\mathrm{~N} / \mathrm{A}$ & 880 & 730 & $\mathrm{~N} / \mathrm{A}$ & 9.3 & 11 & 210 & 230 & 130 & 150 & $\mathrm{~N} / \mathrm{A}$ \\
\hline Fluoride & 1.1 & 0.89 & N/A & 0.11 & 0.11 & $\mathrm{~N} / \mathrm{A}$ & 4.0 & 3.2 & $0.00 \mathrm{~B}$ & 0.12 & 0.79 & 1.2 & $\mathrm{~N} / \mathrm{A}$ \\
\hline Nitrate & $0.047 \mathrm{~B}$ & 0.27 & N/A & $0.10 \mathrm{U}$ & 0.27 & $0.10 \mathrm{U}$ & 7.4 & 2.7 & 1.6 & 1.5 & 2.6 & 0.74 & N/A \\
\hline Sulfate & 460 & 410 & N/A & 73 & 94 & N/A & 80 & 2.8 & 120 & 100 & 420 & 320 & N/A \\
\hline Total Dissolved Solids & 1380 & NS & $\mathrm{N} / \mathrm{A}$ & 2040 & NS & N/A & 580 & NS & 568 & NS & 814 & $\mathrm{NS}$ & N/A \\
\hline Total Alkalinity & 66.6 & 176 & N/A & 202 & 229 & $\mathrm{~N} / \mathrm{A}$ & 553 & 575 & 81.3 & 152 & 207 & 147 & $\mathrm{~N} / \mathrm{A}$ \\
\hline
\end{tabular}

B - Less than five times in the associated blank.

N/A - Not applicable.

NS - Not sampled.

$\mathrm{U}$ - Not detected. 
Table 12 (continued)

Results of Analysis - Groundwater Samples

Valley Fill (Continued) - Groundwater Characteristics Constituents

\begin{tabular}{|c|c|c|c|c|c|c|c|c|c|c|c|}
\hline \multirow[t]{2}{*}{ Constituent } & \multicolumn{8}{|c|}{$\begin{array}{l}\text { Well Number and Sample Date } \\
\text { VFW-12 }\end{array}$} & \multirow{2}{*}{$\begin{array}{c}\text { VFW-13-1 } \\
4 / 28 / 98 \\
\end{array}$} & \multicolumn{2}{|c|}{ VFW-14 } \\
\hline & $4 / 29 / 98$ & $9 / 29 / 98$ & $4 / 29 / 98$ & $9 / 29 / 98$ & 4/29/98 & $9 / 29 / 98$ & $4 / 28 / 98$ & 9/30/98 & & $4 / 28 / 98$ & $9 / 30 / 98$ \\
\hline \multicolumn{12}{|l|}{ Inorganics (ug/l) } \\
\hline Aluminum & $50 \mathrm{U}$ & $50 \mathrm{U}$ & 930 & 1600 & $50 \mathrm{U}$ & $50 \mathrm{U}$ & 76 & 69 & N/A & 57 & $50 \mathrm{U}$ \\
\hline Boron & 48 & 23 & 1800 & 320 & 120 & 97 & 180 & 120 & $\mathrm{~N} / \mathrm{A}$ & 140 & 120 \\
\hline Calcium & 220000 & 200000 & 5100 & 2600 & 280000 & 250000 & 16000 & 7100 & $\mathrm{~N} / \mathrm{A}$ & 320000 & 3800 \\
\hline Iron & 64 & $30 \mathrm{U}$ & 400 & 710 & 45 & 64 & $30 \mathrm{U}$ & 54 & N/A & 160 & 440 \\
\hline Magnesium & 57000 & 53000 & 960 & 780 & 84000 & 81000 & 6000 & 1600 & N/A & 70000 & 740 \\
\hline Manganese & 78 & 190 & 31 & 10 & 410 & 620 & 18 & 10 & N/A & 1400 & 2100 \\
\hline Nickel & 370 & 280 & $10 \mathrm{U}$ & $10 \mathrm{U}$ & 330 & 290 & 28 & 23 & $\mathrm{~N} / \mathrm{A}$ & $10 \mathrm{U}$ & $10 \mathrm{U}$ \\
\hline Phosphorus & $50 \mathrm{U}$ & NS & 150 & NS & $50 \mathrm{U}$ & NS & $50 \mathrm{U}$ & NS & N/A & $50 \mathrm{U}$ & NS \\
\hline Potassium & 1900 & 10000 & 8800 & 1600 & 3600 & 3000 & 1100 & 980 & N/A & 5000 & 4800 \\
\hline Silicon & 2700 & 2400 & 2400 & 4100 & 3700 & 3800 & 3400 & 2300 & $\mathrm{~N} / \mathrm{A}$ & 5100 & 5900 \\
\hline Sodium & 19000 & 24000 & 830000 & 480000 & 77000 & 37000 & 420000 & 200000 & $\mathrm{~N} / \mathrm{A}$ & 410000 & 240000 \\
\hline Strontium & 430 & 370 & 200 & 110 & 1600 & 1400 & 440 & 140 & N/A & 1400 & 1200 \\
\hline \multicolumn{12}{|c|}{ Quality Parameters (mg/l) } \\
\hline Chloride & 310 & 280 & 9.7 & 10 & 370 & 360 & 140 & 130 & 140 & 660 & 570 \\
\hline Fluoride & 0.12 & 0.13 & 8.3 & 8.2 & 0.30 & 0.24 & 0.82 & 0.65 & 0.86 & 0.33 & 0.20 \\
\hline Nitrate & 0.16 & 0.36 & 8.2 & 8.8 & 0.34 & 0.46 & 0.42 & 1.9 & $\mathrm{~N} / \mathrm{A}$ & $0.0010 \mathrm{~B}$ & 0.31 \\
\hline Sulfate & 220 & 120 & 43 & 3.0 & 260 & 160 & 64 & 32 & 64 & 130 & 160 \\
\hline Total Dissolved Solids & 904 & NS & 912 & NS & 884 & NS & 452 & NS & 453 & 1500 & NS \\
\hline Total Alkalinity & 163 & 180 & 931 & 973 & 203 & 217 & 257 & 214 & 259 & 205 & 273 \\
\hline
\end{tabular}

B - Less than five times in the associated blank.

N/A - Not applicable.

NS - Not sampled.

$\mathrm{U}$ - Not detected. 
TABLE 13

FETC-PGH 1998 Groundwater Detection Monitoring Program

Results of Analysis - Groundwater Samples

Main Plateau - Pesticides/PCB Constituents (UG/L)

\begin{tabular}{|c|c|c|c|c|c|c|c|c|c|}
\hline \multirow{3}{*}{ Constituent } & \multicolumn{9}{|c|}{ Well Number and Sample Date } \\
\hline & \multicolumn{2}{|c|}{ MPW-1 } & \multicolumn{2}{|c|}{ MPW-4 } & \multirow{2}{*}{$\begin{array}{c}\text { MPW-4-1 } \\
\text { 9/30/98 } \\
\end{array}$} & \multicolumn{2}{|c|}{ MPW-4D } & \multicolumn{2}{|c|}{ MPW-12 } \\
\hline & $4 / 28 / 98$ & $9 / 29 / 98$ & $4 / 29 / 98$ & 9/30/98 & & $4 / 29 / 98$ & 9/30/98 & $4 / 28 / 98$ & 9/30/98 \\
\hline 4,4'-DDD & $0.10 \mathrm{U}$ & $0.10 \mathrm{U}$ & $0.10 \mathrm{U}$ & $0.10 \mathrm{U}$ & $0.10 \mathrm{U}$ & $0.10 \mathrm{U}$ & $0.10 \mathrm{U}$ & $0.10 \mathrm{U}$ & $0.10 \mathrm{U}$ \\
\hline 4,4'-DDE & $0.070 \mathrm{U}$ & $0.0035 \mathrm{~J}$ & $0.10 \mathrm{U}$ & $0.0021 \mathrm{~J}$ & $0.10 \mathrm{U}$ & $0.10 \mathrm{U}$ & $0.0024 \mathrm{~J}$ & $0.10 \mathrm{U}$ & $0.0017 \mathrm{~J}$ \\
\hline 4,4'-DDT & $0.10 \mathrm{U}$ & $0.077 \mathrm{~J}$ & $0.10 \mathrm{U}$ & $0.028 \mathrm{~J}$ & $0.045 \mathrm{~J}$ & $0.10 \mathrm{U}$ & $0.027 \mathrm{~J}$ & $0.10 \mathrm{U}$ & $0.036 \mathrm{~J}$ \\
\hline Aldrin & $0.050 \mathrm{U}$ & $0.050 \mathrm{U}$ & $0.050 \mathrm{U}$ & $0.0056 \mathrm{~J}$ & $0.050 \mathrm{U}$ & $0.050 \mathrm{U}$ & $0.050 \mathrm{U}$ & $0.050 \mathrm{U}$ & $0.050 \mathrm{U}$ \\
\hline alpha-BHC & $0.050 \mathrm{U}$ & $0.050 \mathrm{U}$ & $0.050 \mathrm{U}$ & $0.050 \mathrm{U}$ & $0.050 \mathrm{U}$ & $0.050 \mathrm{U}$ & $0.050 \mathrm{U}$ & $0.050 \mathrm{U}$ & $0.050 \mathrm{U}$ \\
\hline alpha-Chlordane & $0.10 \mathrm{U}$ & $0.10 \mathrm{U}$ & $0.10 \mathrm{U}$ & $0.00079 \mathrm{~J}$ & $0.0087 \mathrm{~J}$ & $0.10 \mathrm{U}$ & $0.10 \mathrm{U}$ & $0.10 \mathrm{U}$ & $0.00075 \mathrm{~J}$ \\
\hline beta-BHC & $0.050 \mathrm{U}$ & $0.0056 \mathrm{~J}$ & $0.050 \mathrm{U}$ & $0.0026 \mathrm{~J}$ & $0.050 \mathrm{U}$ & $0.050 \mathrm{U}$ & $0.050 \mathrm{U}$ & $0.050 \mathrm{U}$ & $0.050 \mathrm{U}$ \\
\hline delta-BHC & $0.050 \mathrm{U}$ & $0.0034 \mathrm{~J}$ & $0.050 \mathrm{U}$ & $0.0023 \mathrm{~J}$ & $0.0025 \mathrm{~J}$ & $0.050 \mathrm{U}$ & $0.0039 \mathrm{~J}$ & $0.050 \mathrm{U}$ & $0.050 \mathrm{U}$ \\
\hline Dieldrin & $0.070 \mathrm{U}$ & $0.00089 \mathrm{~J}$ & $0.10 \mathrm{U}$ & $0.10 \mathrm{U}$ & $0.10 \mathrm{U}$ & $0.10 \mathrm{U}$ & $0.10 \mathrm{U}$ & $0.10 \mathrm{U}$ & $0.011 \mathrm{~J}$ \\
\hline Endosulfan I & $0.050 \mathrm{U}$ & $0.050 \mathrm{U}$ & $0.050 \mathrm{U}$ & $0.050 \mathrm{U}$ & $0.050 \mathrm{U}$ & $0.050 \mathrm{U}$ & $0.050 \mathrm{U}$ & $0.050 \mathrm{U}$ & $0.050 \mathrm{U}$ \\
\hline Endosulfan II & $0.10 \mathrm{U}$ & $0.0026 \mathrm{~J}$ & $0.10 \mathrm{U}$ & $0.0016 \mathrm{~J}$ & $0.10 \mathrm{U}$ & $0.10 \mathrm{U}$ & $0.0014 \mathrm{~J}$ & $0.10 \mathrm{U}$ & $0.10 \mathrm{U}$ \\
\hline Endosulfan Sulfate & $0.10 \mathrm{U}$ & $0.0060 \mathrm{~J}$ & $0.10 \mathrm{U}$ & $0.010 \mathrm{~J}$ & $0.016 \mathrm{~J}$ & $0.10 \mathrm{U}$ & $0.010 \mathrm{~J}$ & $0.10 \mathrm{U}$ & $0.0055 \mathrm{~J}$ \\
\hline Endrin & $0.10 \mathrm{U}$ & $0.0017 \mathrm{~J}$ & $0.10 \mathrm{U}$ & $0.10 \mathrm{U}$ & $0.0021 \mathrm{~J}$ & $0.10 \mathrm{U}$ & $0.0098 \mathrm{~J}$ & $0.10 \mathrm{U}$ & $0.0062 \mathrm{~J}$ \\
\hline Endrin aldehyde & $0.10 \mathrm{U}$ & $0.10 \mathrm{U}$ & $0.10 \mathrm{U}$ & $0.10 \mathrm{U}$ & $0.10 \mathrm{U}$ & $0.10 \mathrm{U}$ & $0.10 \mathrm{U}$ & $0.10 \mathrm{U}$ & $0.10 \mathrm{U}$ \\
\hline Endrin ketone & $0.10 \mathrm{U}$ & $0.0069 \mathrm{~J}$ & $0.10 \mathrm{U}$ & $0.0054 \mathrm{~J}$ & $0.0035 \mathrm{~J}$ & $0.10 \mathrm{U}$ & $0.0054 \mathrm{~J}$ & $0.10 \mathrm{U}$ & $0.0058 \mathrm{~J}$ \\
\hline gamma-BHC (Lindane) & $0.050 \mathrm{U}$ & $0.0020 \mathrm{~J}$ & $0.050 \mathrm{U}$ & $0.0013 \mathrm{~J}$ & $0.0013 \mathrm{~J}$ & $0.050 \mathrm{U}$ & $0.0018 \mathrm{~J}$ & $0.050 \mathrm{U}$ & $0.0064 \mathrm{~J}$ \\
\hline gamma-Chlordane & $0.10 \mathrm{U}$ & $0.10 \mathrm{U}$ & $0.10 \mathrm{U}$ & $0.10 \mathrm{U}$ & $0.00080 \mathrm{~J}$ & $0.10 \mathrm{U}$ & $0.00066 \mathrm{~J}$ & $0.10 \mathrm{U}$ & $0.10 \mathrm{U}$ \\
\hline Heptachlor & $0.050 \mathrm{U}$ & $0.0014 \mathrm{~J}$ & $0.050 \mathrm{U}$ & $0.0015 \mathrm{~J}$ & $0.0016 \mathrm{~J}$ & $0.050 \mathrm{U}$ & $0.0035 \mathrm{~J}$ & $0.050 \mathrm{U}$ & $0.0069 \mathrm{~J}$ \\
\hline Heptachlor epoxide & $0.050 \mathrm{U}$ & $0.0023 \mathrm{~J}$ & $0.050 \mathrm{U}$ & $0.0022 \mathrm{~J}$ & $0.0021 \mathrm{~J}$ & $0.050 \mathrm{U}$ & $0.050 \mathrm{U}$ & $0.050 \mathrm{U}$ & $0.0049 \mathrm{~J}$ \\
\hline Methoxychlor & $0.50 \mathrm{U}$ & $0.029 \mathrm{~J}$ & $0.50 \mathrm{U}$ & $0.038 \mathrm{~J}$ & $0.060 \mathrm{~J}$ & $0.50 \mathrm{U}$ & $0.026 \mathrm{~J}$ & $0.50 \mathrm{U}$ & $0.029 \mathrm{~J}$ \\
\hline Toxaphene & $1.0 \mathrm{U}$ & $1.0 \mathrm{U}$ & $1.0 \mathrm{U}$ & $1.0 \mathrm{U}$ & $1.0 \mathrm{U}$ & $1.0 \mathrm{U}$ & $1.0 \mathrm{U}$ & $1.0 \mathrm{U}$ & $1.0 \mathrm{U}$ \\
\hline Aroclor-1016 & $1.0 \mathrm{U}$ & $1.0 \mathrm{U}$ & $1.0 \mathrm{U}$ & $1.0 \mathrm{U}$ & $1.0 \mathrm{U}$ & $1.0 \mathrm{U}$ & $1.0 \mathrm{U}$ & $1.0 \mathrm{U}$ & $1.0 \mathrm{U}$ \\
\hline Aroclor-1221 & $1.0 \mathrm{U}$ & $1.0 \mathrm{U}$ & $1.0 \mathrm{U}$ & $1.0 \mathrm{U}$ & $1.0 \mathrm{U}$ & $1.0 \mathrm{U}$ & $1.0 \mathrm{U}$ & $1.0 \mathrm{U}$ & $1.0 \mathrm{U}$ \\
\hline Aroclor-1232 & $1.0 \mathrm{U}$ & $1.0 \mathrm{U}$ & $1.0 \mathrm{U}$ & $1.0 \mathrm{U}$ & $1.0 \mathrm{U}$ & $1.0 \mathrm{U}$ & $1.0 \mathrm{U}$ & $1.0 \mathrm{U}$ & $1.0 \mathrm{U}$ \\
\hline Aroclor-1242 & $1.0 \mathrm{U}$ & $1.0 \mathrm{U}$ & $1.0 \mathrm{U}$ & $1.0 \mathrm{U}$ & $1.0 \mathrm{U}$ & $1.0 \mathrm{U}$ & $1.0 \mathrm{U}$ & $1.0 \mathrm{U}$ & $1.0 \mathrm{U}$ \\
\hline Aroclor-1248 & $1.0 \mathrm{U}$ & $1.0 \mathrm{U}$ & $1.0 \mathrm{U}$ & $1.0 \mathrm{U}$ & $1.0 \mathrm{U}$ & $1.0 \mathrm{U}$ & $1.0 \mathrm{U}$ & $1.0 \mathrm{U}$ & $1.0 \mathrm{U}$ \\
\hline Aroclor-1254 & $1.0 \mathrm{U}$ & $1.0 \mathrm{U}$ & $1.0 \mathrm{U}$ & $1.0 \mathrm{U}$ & $1.0 \mathrm{U}$ & $1.0 \mathrm{U}$ & $1.0 \mathrm{U}$ & $1.0 \mathrm{U}$ & $1.0 \mathrm{U}$ \\
\hline Aroclor-1260 & $1.0 \mathrm{U}$ & $1.0 \mathrm{U}$ & $1.0 \mathrm{U}$ & $1.0 \mathrm{U}$ & $1.0 \mathrm{U}$ & $1.0 \mathrm{U}$ & $1.0 \mathrm{U}$ & $1.0 \mathrm{U}$ & $1.0 \mathrm{U}$ \\
\hline
\end{tabular}

J - Quantitative estimate.

$\mathrm{U}$ - Not detected. 
TABLE 14

FETC-PGH 1998 Groundwater Detection Monitoring Program

Results of Analysis - Groundwater Samples

Valley Fill - Pesticides/PCB Constituents (UG/L)

\begin{tabular}{|l|c|c|c|c|c|}
\hline \multicolumn{5}{r}{ Constituent } & \multicolumn{5}{c}{ Well Number and Sample Date } \\
& $4 / 28 / 98$ & $4 / 29 / 98$ & $4 / 28 / 98$ & $4 / 28 / 98$ & $9 / 30 / 98$ \\
\hline 4,4'-DDD & $0.10 \mathrm{U}$ & $0.10 \mathrm{U}$ & $0.10 \mathrm{U}$ & $0.10 \mathrm{U}$ & $0.10 \mathrm{U}$ \\
\hline \hline 4,4'-DDE & $0.10 \mathrm{U}$ & $0.0013 \mathrm{~J}$ & $0.10 \mathrm{U}$ & $0.050 \mathrm{U}$ & $0.0014 \mathrm{~J}$ \\
\hline \hline 4,4'-DDT & $0.10 \mathrm{U}$ & $0.023 \mathrm{~J}$ & $0.10 \mathrm{U}$ & $0.10 \mathrm{U}$ & $0.0046 \mathrm{~J}$ \\
\hline \hline Aldrin & $0.050 \mathrm{U}$ & $0.0039 \mathrm{~J}$ & $0.050 \mathrm{U}$ & $0.050 \mathrm{U}$ & $0.050 \mathrm{U}$ \\
\hline \hline alpha-BHC & $0.050 \mathrm{U}$ & $0.00094 \mathrm{~J}$ & $0.050 \mathrm{U}$ & $0.050 \mathrm{U}$ & $0.0010 \mathrm{~J}$ \\
\hline \hline alpha-Chlordane & $0.10 \mathrm{U}$ & $0.10 \mathrm{U}$ & $0.10 \mathrm{U}$ & $0.10 \mathrm{U}$ & $0.10 \mathrm{U}$ \\
\hline \hline beta-BHC & $0.050 \mathrm{U}$ & $0.0035 \mathrm{~J}$ & $0.050 \mathrm{U}$ & $0.050 \mathrm{U}$ & $0.0044 \mathrm{~J}$ \\
\hline \hline delta-BHC & $0.050 \mathrm{U}$ & $0.050 \mathrm{U}$ & $0.050 \mathrm{U}$ & $0.050 \mathrm{U}$ & $0.050 \mathrm{U}$ \\
\hline \hline Dieldrin & $0.10 \mathrm{U}$ & $0.040 \mathrm{~J}$ & $0.10 \mathrm{U}$ & $0.050 \mathrm{U}$ & $0.10 \mathrm{U}$ \\
\hline \hline Endosulfan I & $0.050 \mathrm{U}$ & $0.0010 \mathrm{~J}$ & $0.050 \mathrm{U}$ & $0.050 \mathrm{U}$ & $0.050 \mathrm{U}$ \\
\hline \hline Endosulfan II & $0.10 \mathrm{U}$ & $0.0014 \mathrm{~J}$ & $0.10 \mathrm{U}$ & $0.10 \mathrm{U}$ & $0.0013 \mathrm{~J}$ \\
\hline \hline Endosulfan Sulfate & $0.10 \mathrm{U}$ & $0.0093 \mathrm{~J}$ & $0.10 \mathrm{U}$ & $0.10 \mathrm{U}$ & $0.10 \mathrm{U}$ \\
\hline \hline Endrin & $0.10 \mathrm{U}$ & $0.10 \mathrm{U}$ & $0.10 \mathrm{U}$ & $0.10 \mathrm{U}$ & $0.10 \mathrm{U}$ \\
\hline \hline Endrin aldehyde & $0.10 \mathrm{U}$ & $0.0066 \mathrm{~J}$ & $0.10 \mathrm{U}$ & $0.10 \mathrm{U}$ & $0.10 \mathrm{U}$ \\
\hline \hline Endrin ketone & $0.10 \mathrm{U}$ & $0.0054 \mathrm{~J}$ & $0.10 \mathrm{U}$ & $0.10 \mathrm{U}$ & $0.0056 \mathrm{~J}$ \\
\hline \hline gamma-BHC (Lindane) & $0.050 \mathrm{U}$ & $0.0060 \mathrm{~J}$ & $0.050 \mathrm{U}$ & $0.050 \mathrm{U}$ & $0.0012 \mathrm{~J}$ \\
\hline \hline gamma-Chlordane & $0.10 \mathrm{U}$ & $0.10 \mathrm{U}$ & $0.10 \mathrm{U}$ & $0.10 \mathrm{U}$ & $0.10 \mathrm{U}$ \\
\hline \hline Heptachlor & $0.050 \mathrm{U}$ & $0.0015 \mathrm{~J}$ & $0.050 \mathrm{U}$ & $0.050 \mathrm{U}$ & $0.050 \mathrm{U}$ \\
\hline \hline Heptachlor epoxide & $0.050 \mathrm{U}$ & $0.0026 \mathrm{~J}$ & $0.050 \mathrm{U}$ & $0.050 \mathrm{U}$ & $0.0022 \mathrm{~J}$ \\
\hline \hline Methoxychlor & $0.50 \mathrm{U}$ & $0.033 \mathrm{~J}$ & $0.50 \mathrm{U}$ & $0.50 \mathrm{U}$ & $0.030 \mathrm{~J}$ \\
\hline \hline Toxaphene & $1.0 \mathrm{U}$ & $1.0 \mathrm{U}$ & $1.0 \mathrm{U}$ & $1.0 \mathrm{U}$ & $1.0 \mathrm{U}$ \\
\hline \hline Aroclor-1016 & $1.0 \mathrm{U}$ & $1.0 \mathrm{U}$ & $1.0 \mathrm{U}$ & $1.0 \mathrm{U}$ & $1.0 \mathrm{U}$ \\
\hline \hline Aroclor-1221 & $1.0 \mathrm{U}$ & $1.0 \mathrm{U}$ & $1.0 \mathrm{U}$ & $1.0 \mathrm{U}$ & $1.0 \mathrm{U}$ \\
\hline \hline Aroclor-1232 & $1.0 \mathrm{U}$ & $1.0 \mathrm{U}$ & $1.0 \mathrm{U}$ & $1.0 \mathrm{U}$ & $1.0 \mathrm{U}$ \\
\hline \hline Aroclor-1242 & $1.0 \mathrm{U}$ & $1.0 \mathrm{U}$ & $1.0 \mathrm{U}$ & $1.0 \mathrm{U}$ & $1.0 \mathrm{U}$ \\
\hline \hline Aroclor-1248 & $1.0 \mathrm{U}$ & $1.0 \mathrm{U}$ & $1.0 \mathrm{U}$ & $1.0 \mathrm{U}$ & $1.0 \mathrm{U}$ \\
\hline \hline Aroclor-1254 & $1.0 \mathrm{U}$ & $1.0 \mathrm{U}$ & $1.0 \mathrm{U}$ & $1.0 \mathrm{U}$ & $1.0 \mathrm{U}$ \\
\hline \hline Aroclor-1260 & $1.0 \mathrm{U}$ & $1.0 \mathrm{U}$ & $1.0 \mathrm{U}$ & $1.0 \mathrm{U}$ & $1.0 \mathrm{U}$ \\
\hline
\end{tabular}

J - Quantitative estimate. U - Not detected. 
TABLE 15

FETC-PGH 1998 Groundwater Detection Monitoring Program

Results of Analysis - Groundwater Samples

Main Plateau - Semivolatile Organic Compounds Constituents (UG/L)

\begin{tabular}{|c|c|c|c|c|c|}
\hline \multirow{3}{*}{ Constituent } & \multicolumn{5}{|c|}{ Well Number and Sample Date } \\
\hline & \multicolumn{2}{|c|}{ MPW-1 } & \multicolumn{2}{|c|}{ MPW-7 } & \multirow{2}{*}{$\begin{array}{c}\text { MPW-7-1 } \\
\text { 9/29/98 } \\
\end{array}$} \\
\hline & $4 / 28 / 98$ & $9 / 29 / 98$ & $4 / 28 / 98$ & $9 / 29 / 98$ & \\
\hline 1,2,4-Trichlorobenzene & $10 \mathrm{U}$ & $10 \mathrm{U}$ & $10 \mathrm{U}$ & $10 \mathrm{U}$ & $10 \mathrm{U}$ \\
\hline 1,2-Dichlorobenzene & $10 \mathrm{U}$ & $10 \mathrm{U}$ & $10 \mathrm{U}$ & $10 \mathrm{U}$ & $10 \mathrm{U}$ \\
\hline 1,3-Dichlorobenzene & $10 \mathrm{U}$ & $10 \mathrm{U}$ & $10 \mathrm{U}$ & $10 \mathrm{U}$ & $10 \mathrm{U}$ \\
\hline 1,4-Dichlorobenzene & $10 \mathrm{U}$ & $10 \mathrm{U}$ & $10 \mathrm{U}$ & $10 \mathrm{U}$ & $10 \mathrm{U}$ \\
\hline 2,4,5-Trichlorophenol & $25 \mathrm{U}$ & $25 \mathrm{U}$ & $25 \mathrm{U}$ & $25 \mathrm{U}$ & $25 \mathrm{U}$ \\
\hline 2,4,6-Trichlorophenol & $10 \mathrm{U}$ & $10 \mathrm{U}$ & $10 \mathrm{U}$ & $10 \mathrm{U}$ & $10 \mathrm{U}$ \\
\hline 2,4-Dichlorophenol & $10 \mathrm{U}$ & $10 \mathrm{U}$ & $10 \mathrm{U}$ & $10 \mathrm{U}$ & $10 \mathrm{U}$ \\
\hline 2,4-Dimethylphenol & $10 \mathrm{U}$ & $10 \mathrm{U}$ & $10 \mathrm{U}$ & $10 \mathrm{U}$ & $10 \mathrm{U}$ \\
\hline 2,4-Dinitrophenol & $25 \mathrm{U}$ & $25 \mathrm{U}$ & $25 \mathrm{U}$ & $25 \mathrm{U}$ & $25 \mathrm{U}$ \\
\hline 2,4-Dinitrotoulene & $10 \mathrm{U}$ & $10 \mathrm{U}$ & $10 \mathrm{U}$ & $10 \mathrm{U}$ & $10 \mathrm{U}$ \\
\hline 2,6-Dinitrotoluene & $10 \mathrm{U}$ & $10 \mathrm{U}$ & $10 \mathrm{U}$ & $10 \mathrm{U}$ & $10 \mathrm{U}$ \\
\hline 2-Chloronaphthalene & $10 \mathrm{U}$ & $10 \mathrm{U}$ & $10 \mathrm{U}$ & $10 \mathrm{U}$ & $10 \mathrm{U}$ \\
\hline 2-Chlorophenol & $10 \mathrm{U}$ & $10 \mathrm{U}$ & $10 \mathrm{U}$ & $10 \mathrm{U}$ & $10 \mathrm{U}$ \\
\hline 2-Methylnaphthalene & $10 \mathrm{U}$ & $10 \mathrm{U}$ & $10 \mathrm{U}$ & $10 \mathrm{U}$ & $10 \mathrm{U}$ \\
\hline 2-Methylphenol (o-Cresol) & $10 \mathrm{U}$ & $10 \mathrm{U}$ & $10 \mathrm{U}$ & $10 \mathrm{U}$ & $10 \mathrm{U}$ \\
\hline 2-Nitroaniline & $25 \mathrm{U}$ & $25 \mathrm{U}$ & $25 \mathrm{U}$ & $25 \mathrm{U}$ & $25 \mathrm{U}$ \\
\hline 2-Nitrophenol & $10 \mathrm{U}$ & $10 \mathrm{U}$ & $10 \mathrm{U}$ & $10 \mathrm{U}$ & $10 \mathrm{U}$ \\
\hline 3,3'-Dichlorobenzidine & $10 \mathrm{U}$ & $10 \mathrm{U}$ & $10 \mathrm{U}$ & $10 \mathrm{U}$ & $10 \mathrm{U}$ \\
\hline 3-Nitroaniline & $25 \mathrm{U}$ & $25 \mathrm{U}$ & $25 \mathrm{U}$ & $25 \mathrm{U}$ & $25 \mathrm{U}$ \\
\hline 4,6-Dinitro-2-methlyphenol & $25 \mathrm{U}$ & $25 \mathrm{U}$ & $25 \mathrm{U}$ & $25 \mathrm{U}$ & $25 \mathrm{U}$ \\
\hline 4-Bromophenyl phenyl ether & $10 \mathrm{U}$ & $10 \mathrm{U}$ & $10 \mathrm{U}$ & $10 \mathrm{U}$ & $10 \mathrm{U}$ \\
\hline 4-Chloro-3-methylphenol & $10 \mathrm{U}$ & $10 \mathrm{U}$ & $10 \mathrm{U}$ & $10 \mathrm{U}$ & $10 \mathrm{U}$ \\
\hline 4-Chloroaniline & $10 \mathrm{U}$ & $10 \mathrm{U}$ & $10 \mathrm{U}$ & $10 \mathrm{U}$ & $10 \mathrm{U}$ \\
\hline 4-Chlorodiphenyl ether & $10 \mathrm{U}$ & $10 \mathrm{U}$ & $10 \mathrm{U}$ & $10 \mathrm{U}$ & $10 \mathrm{U}$ \\
\hline 4-Methylphenol (p-Cresol) & $10 \mathrm{U}$ & $10 \mathrm{U}$ & $10 \mathrm{U}$ & $10 \mathrm{U}$ & $10 \mathrm{U}$ \\
\hline 4-Nitroaniline & $25 \mathrm{U}$ & $25 \mathrm{U}$ & $25 \mathrm{U}$ & $25 \mathrm{U}$ & $25 \mathrm{U}$ \\
\hline 4-Nitrophenol & $25 \mathrm{U}$ & $25 \mathrm{U}$ & $25 \mathrm{U}$ & $25 \mathrm{U}$ & $25 \mathrm{U}$ \\
\hline Acenaphthene & $10 \mathrm{U}$ & $10 \mathrm{U}$ & $10 \mathrm{U}$ & $10 \mathrm{U}$ & $10 \mathrm{U}$ \\
\hline Acenaphthylene & $10 \mathrm{U}$ & $10 \mathrm{U}$ & $10 \mathrm{U}$ & $10 \mathrm{U}$ & $10 \mathrm{U}$ \\
\hline Anthracene & $10 \mathrm{U}$ & $10 \mathrm{U}$ & $10 \mathrm{U}$ & $10 \mathrm{U}$ & $10 \mathrm{U}$ \\
\hline Benzo(a)anthracene & $10 \mathrm{U}$ & $10 \mathrm{U}$ & $10 \mathrm{U}$ & $10 \mathrm{U}$ & $10 \mathrm{U}$ \\
\hline Benzo(a)pyrene & $10 \mathrm{U}$ & $10 \mathrm{U}$ & $10 \mathrm{U}$ & $10 \mathrm{U}$ & $10 \mathrm{U}$ \\
\hline
\end{tabular}

U - Undected. 


\section{TABLE 15 (continued)}

Results of Analysis - Groundwater Samples

Main Plateau (Continued) - Semivolatile Organic Compounds Constituents (UG/L)

\begin{tabular}{|l|c|c|c|c|c|}
\hline \multicolumn{5}{|c}{ Constituent } & \multicolumn{5}{c}{ Well Number and Sample Date } \\
& $4 / 28 / 98$ & $9 / 29 / 98$ & $4 / 28 / 98$ & $9 / 29 / 98$ & $9 / 29 / 98$ \\
\hline & $10 \mathrm{U}$ & $10 \mathrm{U}$ & $10 \mathrm{U}$ & $10 \mathrm{U}$ & $10 \mathrm{U}$ \\
\hline Benzo(b)fluoranthene & $10 \mathrm{U}$ & $10 \mathrm{U}$ & $10 \mathrm{U}$ & $10 \mathrm{U}$ & $10 \mathrm{U}$ \\
\hline Benzo(ghi)perylene & $10 \mathrm{U}$ & $10 \mathrm{U}$ & $10 \mathrm{U}$ & $10 \mathrm{U}$ & $10 \mathrm{U}$ \\
\hline Benzo(k)fluoranthene & $10 \mathrm{U}$ & $10 \mathrm{U}$ & $10 \mathrm{U}$ & $10 \mathrm{U}$ & $10 \mathrm{U}$ \\
\hline Bis(2-chloroethoxyl) methane & $10 \mathrm{U}$ & $10 \mathrm{U}$ & $25 \mathrm{U}$ & $10 \mathrm{U}$ & $10 \mathrm{U}$ \\
\hline Bis (2-chloroethyl) ether & $10 \mathrm{U}$ & $10 \mathrm{U}$ & $10 \mathrm{U}$ & $10 \mathrm{U}$ & $10 \mathrm{U}$ \\
\hline Bis(2-chloroisopropyl) ether & $10 \mathrm{U}$ & $10 \mathrm{U}$ & $10 \mathrm{U}$ & $10 \mathrm{U}$ & $10 \mathrm{U}$ \\
\hline Bis(2-ethylhexyl) phthalate & $10 \mathrm{U}$ & $10 \mathrm{U}$ & $10 \mathrm{U}$ & $10 \mathrm{U}$ & $10 \mathrm{U}$ \\
\hline Butyl benzyl phthalate & $10 \mathrm{U}$ & $10 \mathrm{U}$ & $25 \mathrm{U}$ & $10 \mathrm{U}$ & $10 \mathrm{U}$ \\
\hline Carbazole & $10 \mathrm{U}$ & $10 \mathrm{U}$ & $10 \mathrm{U}$ & $10 \mathrm{U}$ & $10 \mathrm{U}$ \\
\hline Chrysene & $10 \mathrm{U}$ & $10 \mathrm{U}$ & $10 \mathrm{U}$ & $10 \mathrm{U}$ & $10 \mathrm{U}$ \\
\hline Di-n-butyl phthalate & $10 \mathrm{U}$ & $10 \mathrm{U}$ & $10 \mathrm{U}$ & $10 \mathrm{U}$ & $10 \mathrm{U}$ \\
\hline Di-n-octly phthalate & $10 \mathrm{U}$ & $10 \mathrm{U}$ & $10 \mathrm{U}$ & $10 \mathrm{U}$ & $10 \mathrm{U}$ \\
\hline Dibenzo(a,h)anthracene & $10 \mathrm{U}$ & $10 \mathrm{U}$ & $10 \mathrm{U}$ & $10 \mathrm{U}$ & $10 \mathrm{U}$ \\
\hline Dibenzofuran & $10 \mathrm{U}$ & $10 \mathrm{U}$ & $10 \mathrm{U}$ & $10 \mathrm{U}$ & $10 \mathrm{U}$ \\
\hline Diethyl phthalate & $10 \mathrm{U}$ & $10 \mathrm{U}$ & $25 \mathrm{U}$ & $10 \mathrm{U}$ & $10 \mathrm{U}$ \\
\hline Dimethyl phthalate & $10 \mathrm{U}$ & $10 \mathrm{U}$ & $10 \mathrm{U}$ & $10 \mathrm{U}$ & $10 \mathrm{U}$ \\
\hline Fluoranthene & $10 \mathrm{U}$ & $10 \mathrm{U}$ & $10 \mathrm{U}$ & $10 \mathrm{U}$ & $10 \mathrm{U}$ \\
\hline Fluorene & $10 \mathrm{U}$ & $10 \mathrm{U}$ & $25 \mathrm{U}$ & $10 \mathrm{U}$ & $10 \mathrm{U}$ \\
\hline Hexachlorobenzene & $10 \mathrm{U}$ & $10 \mathrm{U}$ & $25 \mathrm{U}$ & $10 \mathrm{U}$ & $10 \mathrm{U}$ \\
\hline Hexachlorobutadiene & $10 \mathrm{U}$ & $10 \mathrm{U}$ & $10 \mathrm{U}$ & $10 \mathrm{U}$ & $10 \mathrm{U}$ \\
\hline Hexachlorocyclopentadiene & $10 \mathrm{U}$ & $10 \mathrm{U}$ & $10 \mathrm{U}$ & $10 \mathrm{U}$ & $10 \mathrm{U}$ \\
\hline Hexachloroethane & $10 \mathrm{U}$ & $10 \mathrm{U}$ & $10 \mathrm{U}$ & $10 \mathrm{U}$ & $10 \mathrm{U}$ \\
\hline Indeno(1,2,3-cd)pyrene & $10 \mathrm{U}$ & $10 \mathrm{U}$ & $10 \mathrm{U}$ & $10 \mathrm{U}$ & $10 \mathrm{U}$ \\
\hline Isophorone & $10 \mathrm{U}$ & $10 \mathrm{U}$ & $10 \mathrm{U}$ & $10 \mathrm{U}$ & $10 \mathrm{U}$ \\
\hline N-Nitroso-Di-n-propylamine & $10 \mathrm{U}$ & $10 \mathrm{U}$ & $25 \mathrm{U}$ & $10 \mathrm{U}$ & $10 \mathrm{U}$ \\
\hline N-nitrosodiphenylamine & $10 \mathrm{U}$ & $10 \mathrm{U}$ & $25 \mathrm{U}$ & $10 \mathrm{U}$ & $10 \mathrm{U}$ \\
\hline Naphthalene & $10 \mathrm{U}$ & $10 \mathrm{U}$ & $10 \mathrm{U}$ & $10 \mathrm{U}$ & $10 \mathrm{U}$ \\
\hline Nitrobenzene & $25 \mathrm{U}$ & $25 \mathrm{U}$ & $10 \mathrm{U}$ & $25 \mathrm{U}$ & $25 \mathrm{U}$ \\
\hline Pentachlorophenol & $10 \mathrm{U}$ & $10 \mathrm{U}$ & $10 \mathrm{U}$ & $10 \mathrm{U}$ & $10 \mathrm{U}$ \\
\hline Phenanthrene & $10 \mathrm{U}$ & $10 \mathrm{U}$ & $10 \mathrm{U}$ & $10 \mathrm{U}$ & $10 \mathrm{U}$ \\
\hline Phenol & $10 \mathrm{U}$ & $10 \mathrm{U}$ & $10 \mathrm{U}$ & $10 \mathrm{U}$ & $10 \mathrm{U}$ \\
\hline Pyrene & & & & \\
\hline
\end{tabular}

U - Not detected. 
TABLE 16

FETC-PGH 1998 Groundwater Detection Monitoring Program

Results of Analysis - Groundwater Samples

Valley Fill - Semivolatile Organic Compounds Constituents (UG/L)

\begin{tabular}{|l|c|c|c|c|c|}
\hline \multicolumn{5}{|c}{ Vonstituent } & \multicolumn{4}{c}{ Well Number and Sample Date } \\
\multicolumn{1}{|c|}{$4 / 28 / 98$} & $9 / 29 / 98$ & $4 / 28 / 98$ & $4 / 28 / 98$ & $9 / 30 / 98$ \\
\hline 1,2,4-Trichlorobenzene & $10 \mathrm{U}$ & $10 \mathrm{U}$ & $10 \mathrm{U}$ & $10 \mathrm{U}$ & $10 \mathrm{U}$ \\
\hline 1,2-Dichlorobenzene & $10 \mathrm{U}$ & $10 \mathrm{U}$ & $10 \mathrm{U}$ & $10 \mathrm{U}$ & $10 \mathrm{U}$ \\
\hline 1,3-Dichlorobenzene & $10 \mathrm{U}$ & $10 \mathrm{U}$ & $10 \mathrm{U}$ & $10 \mathrm{U}$ & $10 \mathrm{U}$ \\
\hline 1,4-Dichlorobenzene & $10 \mathrm{U}$ & $10 \mathrm{U}$ & $10 \mathrm{U}$ & $10 \mathrm{U}$ & $10 \mathrm{U}$ \\
\hline 2,4,5-Trichlorophenol & $25 \mathrm{U}$ & $25 \mathrm{U}$ & $25 \mathrm{U}$ & $25 \mathrm{U}$ & $25 \mathrm{U}$ \\
\hline 2,4,6-Trichlorophenol & $10 \mathrm{U}$ & $10 \mathrm{U}$ & $10 \mathrm{U}$ & $10 \mathrm{U}$ & $10 \mathrm{U}$ \\
\hline 2,4-Dichlorophenol & $10 \mathrm{U}$ & $10 \mathrm{U}$ & $10 \mathrm{U}$ & $10 \mathrm{U}$ & $10 \mathrm{U}$ \\
\hline 2,4-Dimethylphenol & $10 \mathrm{U}$ & $10 \mathrm{U}$ & $10 \mathrm{U}$ & $10 \mathrm{U}$ & $10 \mathrm{U}$ \\
\hline 2,4-Dinitrophenol & $25 \mathrm{U}$ & $25 \mathrm{U}$ & $25 \mathrm{U}$ & $25 \mathrm{U}$ & $25 \mathrm{U}$ \\
\hline 2,4-Dinitrotoulene & $10 \mathrm{U}$ & $10 \mathrm{U}$ & $10 \mathrm{U}$ & $10 \mathrm{U}$ & $10 \mathrm{U}$ \\
\hline 2,6-Dinitrotoluene & $10 \mathrm{U}$ & $10 \mathrm{U}$ & $10 \mathrm{U}$ & $10 \mathrm{U}$ & $10 \mathrm{U}$ \\
\hline 2-Chloronaphthalene & $10 \mathrm{U}$ & $10 \mathrm{U}$ & $10 \mathrm{U}$ & $10 \mathrm{U}$ & $10 \mathrm{U}$ \\
\hline 2-Chlorophenol & $10 \mathrm{U}$ & $10 \mathrm{U}$ & $10 \mathrm{U}$ & $10 \mathrm{U}$ & $10 \mathrm{U}$ \\
\hline 2-Methylnaphthalene & $10 \mathrm{U}$ & $10 \mathrm{U}$ & $10 \mathrm{U}$ & $10 \mathrm{U}$ & $10 \mathrm{U}$ \\
\hline 2-Methylphenol (o-Cresol) & $10 \mathrm{U}$ & $10 \mathrm{U}$ & $10 \mathrm{U}$ & $10 \mathrm{U}$ & $10 \mathrm{U}$ \\
\hline 2-Nitroaniline & $25 \mathrm{U}$ & $25 \mathrm{U}$ & $25 \mathrm{U}$ & $25 \mathrm{U}$ & $25 \mathrm{U}$ \\
\hline 2-Nitrophenol & $10 \mathrm{U}$ & $10 \mathrm{U}$ & $10 \mathrm{U}$ & $10 \mathrm{U}$ & $10 \mathrm{U}$ \\
\hline 3,3'-Dichlorobenzidine & $10 \mathrm{U}$ & $10 \mathrm{U}$ & $10 \mathrm{U}$ & $10 \mathrm{U}$ & $10 \mathrm{U}$ \\
\hline 3-Nitroaniline & $25 \mathrm{U}$ & $25 \mathrm{U}$ & $25 \mathrm{U}$ & $25 \mathrm{U}$ & $25 \mathrm{U}$ \\
\hline 4,6-Dinitro-2-methlyphenol & $25 \mathrm{U}$ & $25 \mathrm{U}$ & $25 \mathrm{U}$ & $25 \mathrm{U}$ & $25 \mathrm{U}$ \\
\hline 4-Bromophenyl phenyl ether & $10 \mathrm{U}$ & $10 \mathrm{U}$ & $10 \mathrm{U}$ & $10 \mathrm{U}$ & $10 \mathrm{U}$ \\
\hline 4-Chloro-3-methylphenol & $10 \mathrm{U}$ & $10 \mathrm{U}$ & $10 \mathrm{U}$ & $10 \mathrm{U}$ & $10 \mathrm{U}$ \\
\hline 4-Chloroaniline & $10 \mathrm{U}$ & $10 \mathrm{U}$ & $10 \mathrm{U}$ & $10 \mathrm{U}$ & $10 \mathrm{U}$ \\
\hline 4-Chlorodiphenyl ether & $10 \mathrm{U}$ & $10 \mathrm{U}$ & $10 \mathrm{U}$ & $10 \mathrm{U}$ & $10 \mathrm{U}$ \\
\hline 4-Methylphenol (p-Cresol) & $10 \mathrm{U}$ & $10 \mathrm{U}$ & $10 \mathrm{U}$ & $10 \mathrm{U}$ & $10 \mathrm{U}$ \\
\hline 4-Nitroaniline & $25 \mathrm{U}$ & $25 \mathrm{U}$ & $25 \mathrm{U}$ & $25 \mathrm{U}$ & $25 \mathrm{U}$ \\
\hline 4-Nitrophenol & $25 \mathrm{U}$ & $25 \mathrm{U}$ & $25 \mathrm{U}$ & $25 \mathrm{U}$ & $25 \mathrm{U}$ \\
\hline Acenaphthene & $10 \mathrm{U}$ & $10 \mathrm{U}$ & $10 \mathrm{U}$ & $10 \mathrm{U}$ & $10 \mathrm{U}$ \\
\hline Acenaphthylene & $10 \mathrm{U}$ & $10 \mathrm{U}$ & $10 \mathrm{U}$ & $10 \mathrm{U}$ & $10 \mathrm{U}$ \\
\hline Anthracene & $10 \mathrm{U}$ & $10 \mathrm{U}$ & $10 \mathrm{U}$ & $10 \mathrm{U}$ & $10 \mathrm{U}$ \\
\hline Benzo(a)anthracene & $10 \mathrm{U}$ & $10 \mathrm{U}$ & $10 \mathrm{U}$ & $10 \mathrm{U}$ & $10 \mathrm{U}$ \\
\hline Benzo(a)pyrene & $10 \mathrm{U}$ & $10 \mathrm{U}$ & $10 \mathrm{U}$ & $10 \mathrm{U}$ & $10 \mathrm{U}$ \\
\hline
\end{tabular}

$\mathrm{U}$ - Not detected. 


\section{TABLE 16 (continued)}

Results of Analysis - Groundwater Samples

Valley Fill (Continued) - Semivolatile Organic Compounds Constituents (UG/L)

\begin{tabular}{|l|c|c|c|c|c|}
\hline \multicolumn{5}{|c}{ Constituent } & \multicolumn{5}{c}{ Vell Number and Sample Date } \\
& $4 / 28 / 98$ & $9 / 29 / 98$ & $4 / 28 / 98$ & \multicolumn{2}{c|}{$4 / 28 / 98$} \\
\multicolumn{1}{|c|}{} & $10 \mathrm{U}$ & $10 \mathrm{U}$ & $10 \mathrm{U}$ & $10 \mathrm{U}$ & $10 \mathrm{U}$ \\
\hline Benzo(b)fluoranthene & $10 \mathrm{U}$ & $10 \mathrm{U}$ & $10 \mathrm{U}$ & $10 \mathrm{U}$ & $10 \mathrm{U}$ \\
\hline Benzo(ghi)perylene & $10 \mathrm{U}$ & $10 \mathrm{U}$ & $10 \mathrm{U}$ & $10 \mathrm{U}$ & $10 \mathrm{U}$ \\
\hline Benzo(k)fluoranthene & $10 \mathrm{U}$ & $10 \mathrm{U}$ & $10 \mathrm{U}$ & $10 \mathrm{U}$ & $10 \mathrm{U}$ \\
\hline Bis(2-chloroethoxyl) methane & $10 \mathrm{U}$ & $10 \mathrm{U}$ & $25 \mathrm{U}$ & $10 \mathrm{U}$ & $25 \mathrm{U}$ \\
\hline Bis (2-chloroethyl) ether & $10 \mathrm{U}$ & $10 \mathrm{U}$ & $10 \mathrm{U}$ & $10 \mathrm{U}$ & $10 \mathrm{U}$ \\
\hline Bis(2-chloroisopropyl) ether & $10 \mathrm{U}$ & $10 \mathrm{U}$ & $10 \mathrm{U}$ & $10 \mathrm{U}$ & $10 \mathrm{U}$ \\
\hline Bis(2-ethylhexyl)phthalate & $10 \mathrm{U}$ & $10 \mathrm{U}$ & $10 \mathrm{U}$ & $10 \mathrm{U}$ & $10 \mathrm{U}$ \\
\hline Butyl benzyl phthalate & $10 \mathrm{U}$ & $10 \mathrm{U}$ & $25 \mathrm{U}$ & $10 \mathrm{U}$ & $25 \mathrm{U}$ \\
\hline Carbazole & $10 \mathrm{U}$ & $10 \mathrm{U}$ & $10 \mathrm{U}$ & $10 \mathrm{U}$ & $10 \mathrm{U}$ \\
\hline Chrysene & $10 \mathrm{U}$ & $10 \mathrm{U}$ & $10 \mathrm{U}$ & $10 \mathrm{U}$ & $10 \mathrm{U}$ \\
\hline Di-n-butyl phthalate & $10 \mathrm{U}$ & $10 \mathrm{U}$ & $10 \mathrm{U}$ & $10 \mathrm{U}$ & $10 \mathrm{U}$ \\
\hline Di-n-octly phthalate & $10 \mathrm{U}$ & $10 \mathrm{U}$ & $10 \mathrm{U}$ & $10 \mathrm{U}$ & $10 \mathrm{U}$ \\
\hline Dibenzo(a,h)anthracene & $10 \mathrm{U}$ & $10 \mathrm{U}$ & $10 \mathrm{U}$ & $10 \mathrm{U}$ & $10 \mathrm{U}$ \\
\hline Dibenzofuran & $10 \mathrm{U}$ & $10 \mathrm{U}$ & $10 \mathrm{U}$ & $10 \mathrm{U}$ & $10 \mathrm{U}$ \\
\hline Diethyl phthalate & $10 \mathrm{U}$ & $10 \mathrm{U}$ & $25 \mathrm{U}$ & $10 \mathrm{U}$ & $25 \mathrm{U}$ \\
\hline Dimethyl phthalate & $10 \mathrm{U}$ & $10 \mathrm{U}$ & $10 \mathrm{U}$ & $10 \mathrm{U}$ & $10 \mathrm{U}$ \\
\hline Fluoranthene & $10 \mathrm{U}$ & $10 \mathrm{U}$ & $10 \mathrm{U}$ & $10 \mathrm{U}$ & $10 \mathrm{U}$ \\
\hline Fluorene & $10 \mathrm{U}$ & $10 \mathrm{U}$ & $25 \mathrm{U}$ & $10 \mathrm{U}$ & $25 \mathrm{U}$ \\
\hline Hexachlorobenzene & $10 \mathrm{U}$ & $10 \mathrm{U}$ & $25 \mathrm{U}$ & $10 \mathrm{U}$ & $25 \mathrm{U}$ \\
\hline Hexachlorobutadiene & $10 \mathrm{U}$ & $10 \mathrm{U}$ & $10 \mathrm{U}$ & $10 \mathrm{U}$ & $10 \mathrm{U}$ \\
\hline Hexachlorocyclopentadiene & $10 \mathrm{U}$ & $10 \mathrm{U}$ & $10 \mathrm{U}$ & $10 \mathrm{U}$ & $10 \mathrm{U}$ \\
\hline Hexachloroethane & $10 \mathrm{U}$ & $10 \mathrm{U}$ & $10 \mathrm{U}$ & $10 \mathrm{U}$ & $10 \mathrm{U}$ \\
\hline Indeno(1,2,3-cd)pyrene & $10 \mathrm{U}$ & $10 \mathrm{U}$ & $10 \mathrm{U}$ & $10 \mathrm{U}$ & $10 \mathrm{U}$ \\
\hline Isophorone & $10 \mathrm{U}$ & $10 \mathrm{U}$ & $10 \mathrm{U}$ & $10 \mathrm{U}$ & $10 \mathrm{U}$ \\
\hline N-Nitroso-Di-n-propylamine & $10 \mathrm{U}$ & $10 \mathrm{U}$ & $25 \mathrm{U}$ & $10 \mathrm{U}$ & $25 \mathrm{U}$ \\
\hline N-nitrosodiphenylamine & $10 \mathrm{U}$ & $10 \mathrm{U}$ & $25 \mathrm{U}$ & $10 \mathrm{U}$ & $25 \mathrm{U}$ \\
\hline Naphthalene & $10 \mathrm{U}$ & $10 \mathrm{U}$ & $10 \mathrm{U}$ & $10 \mathrm{U}$ & $10 \mathrm{U}$ \\
\hline Nitrobenzene & $25 \mathrm{U}$ & $25 \mathrm{U}$ & $10 \mathrm{U}$ & $25 \mathrm{U}$ & $10 \mathrm{U}$ \\
\hline Pentachlorophenol & $10 \mathrm{U}$ & $10 \mathrm{U}$ & $10 \mathrm{U}$ & $10 \mathrm{U}$ & $10 \mathrm{U}$ \\
\hline Phenanthrene & $10 \mathrm{U}$ & $10 \mathrm{U}$ & $10 \mathrm{U}$ & $10 \mathrm{U}$ & $10 \mathrm{U}$ \\
\hline Phenol & $10 \mathrm{U}$ & $10 \mathrm{U}$ & $10 \mathrm{U}$ & $10 \mathrm{U}$ \\
\hline Pyrene & & & & \\
\hline
\end{tabular}

U - Not detected. 
TABLE 17

FETC-PGH 1998 Groundwater Detection Monitoring Program

Results of Analysis - Groundwater Samples

Valley Fill - TPH Constituents (MG/L)

\begin{tabular}{|c|c|c|c|c|c|c|c|c|c|c|}
\hline \multirow{3}{*}{ Constituent } & \multicolumn{10}{|c|}{ Well Number and Sample Date } \\
\hline & \multicolumn{2}{|c|}{ VFW-2 } & \multicolumn{2}{|c|}{ VFW-4 } & VFW-4-1 & \multicolumn{2}{|c|}{ VFW-7 } & \multicolumn{2}{|c|}{ VFW-8 } & VFW-9 \\
\hline & $4 / 28 / 98$ & $9 / 29 / 98$ & $4 / 28 / 98$ & $9 / 29 / 98$ & $9 / 29 / 98$ & $4 / 28 / 98$ & $9 / 30 / 98$ & $4 / 28 / 98$ & $9 / 29 / 98$ & $4 / 29 / 98$ \\
\hline TPH-DRO & $1.0 \mathrm{U}$ & $1.0 \mathrm{U}$ & $1.0 \mathrm{U}$ & $0.016 \mathrm{~J}$ & $0.022 \mathrm{~J}$ & $1.0 \mathrm{U}$ & $1.0 \mathrm{U}$ & $1.0 \mathrm{U}$ & $0.042 \mathrm{~J}$ & $1.0 \mathrm{U}$ \\
\hline \multirow{3}{*}{ Constituent } & \multicolumn{10}{|c|}{ Well Number and Sample Date } \\
\hline & VFW-9 & \multicolumn{2}{|c|}{ VFW-10 } & VFW-11 & & \multicolumn{2}{|c|}{ VFW-12 } & \multicolumn{2}{|c|}{ VFW-14 } & VFW-14-1 \\
\hline & N/A & $4 / 29 / 98$ & $9 / 30 / 98$ & $4 / 29 / 98$ & $9 / 29 / 98$ & $4 / 29 / 98$ & $9 / 29 / 98$ & $4 / 28 / 98$ & $9 / 30 / 98$ & $4 / 28 / 98$ \\
\hline TPH-DRO & NS & $1.0 \mathrm{U}$ & $0.027 \mathrm{~J}$ & $1.0 \mathrm{U}$ & $0.017 \mathrm{~J}$ & $1.0 \mathrm{U}$ & $0.017 \mathrm{~J}$ & $1.0 \mathrm{U}$ & $1.0 \mathrm{U}$ & $1.0 \mathrm{U}$ \\
\hline
\end{tabular}

$\mathrm{J}$ - Quantitative estimate.

N/A - Not applicable.

NS - Not sampled.

U - Not detected. 
TABLE 18

FETC-PGH 1998 Groundwater Detection Monitoring Program

Results of Analysis - Groundwater Samples

Main Plateau - Volatile Organic Compounds Constituents (UG/L)

\begin{tabular}{|c|c|c|c|c|c|c|c|c|c|c|c|}
\hline \multirow{3}{*}{ Constituent } & \multicolumn{9}{|c|}{ Well Number and Sample Date } & & \\
\hline & \multicolumn{2}{|c|}{ MPW-1 } & \multicolumn{2}{|c|}{ MPW-3 } & \multicolumn{2}{|c|}{ MPW-7 } & \multirow{2}{*}{$\begin{array}{c}\text { MPW-7-1 } \\
4 / 29 / 98 \\
\end{array}$} & \multicolumn{2}{|c|}{ MPW-7D } & \multicolumn{2}{|c|}{ MPW-8 } \\
\hline & $4 / 28 / 98$ & $9 / 29 / 98$ & $4 / 28 / 98$ & $9 / 29 / 98$ & $4 / 29 / 98$ & $9 / 29 / 98$ & & $4 / 29 / 98$ & $9 / 29 / 98$ & $4 / 28 / 98$ & $9 / 29 / 98$ \\
\hline 1,1,1-Trichloroethane & $5.0 \mathrm{U}$ & $5.0 \mathrm{U}$ & $5.0 \mathrm{U}$ & $5.0 \mathrm{U}$ & $5.0 \mathrm{U}$ & $5.0 \mathrm{U}$ & $5.0 \mathrm{U}$ & $5.0 \mathrm{U}$ & $5.0 \mathrm{U}$ & $5.0 \mathrm{U}$ & $5.0 \mathrm{U}$ \\
\hline 1,1,2,2-Tetrachloroethane & $5.0 \mathrm{U}$ & $5.0 \mathrm{U}$ & $5.0 \mathrm{U}$ & $5.0 \mathrm{U}$ & $5.0 \mathrm{U}$ & $5.0 \mathrm{U}$ & $5.0 \mathrm{U}$ & $5.0 \mathrm{U}$ & $5.0 \mathrm{U}$ & $5.0 \mathrm{U}$ & $5.0 \mathrm{U}$ \\
\hline 1,1,2-Trichloroethane & $5.0 \mathrm{U}$ & $5.0 \mathrm{U}$ & $5.0 \mathrm{U}$ & $5.0 \mathrm{U}$ & $5.0 \mathrm{U}$ & $5.0 \mathrm{U}$ & $5.0 \mathrm{U}$ & $5.0 \mathrm{U}$ & $5.0 \mathrm{U}$ & $5.0 \mathrm{U}$ & $5.0 \mathrm{U}$ \\
\hline 1,1-Dichloroethane & $5.0 \mathrm{U}$ & $5.0 \mathrm{U}$ & $5.0 \mathrm{U}$ & $5.0 \mathrm{U}$ & $5.0 \mathrm{U}$ & $5.0 \mathrm{U}$ & $5.0 \mathrm{U}$ & $5.0 \mathrm{U}$ & $5.0 \mathrm{U}$ & 9.7 & 10 \\
\hline 1,1-Dichloroethene & $5.0 \mathrm{U}$ & $5.0 \mathrm{U}$ & $5.0 \mathrm{U}$ & $5.0 \mathrm{U}$ & $5.0 \mathrm{U}$ & $5.0 \mathrm{U}$ & $5.0 \mathrm{U}$ & $5.0 \mathrm{U}$ & $5.0 \mathrm{U}$ & $5.0 \mathrm{U}$ & $5.0 \mathrm{U}$ \\
\hline 1,2-Dichloroethane & $5.0 \mathrm{U}$ & $5.0 \mathrm{U}$ & $5.0 \mathrm{U}$ & $5.0 \mathrm{U}$ & $5.0 \mathrm{U}$ & $5.0 \mathrm{U}$ & $5.0 \mathrm{U}$ & $5.0 \mathrm{U}$ & $5.0 \mathrm{U}$ & $5.0 \mathrm{U}$ & $5.0 \mathrm{U}$ \\
\hline 1,2-Dichloropropane & $5.0 \mathrm{U}$ & $5.0 \mathrm{U}$ & $5.0 \mathrm{U}$ & $5.0 \mathrm{U}$ & $5.0 \mathrm{U}$ & $5.0 \mathrm{U}$ & $5.0 \mathrm{U}$ & $5.0 \mathrm{U}$ & $5.0 \mathrm{U}$ & $5.0 \mathrm{U}$ & $5.0 \mathrm{U}$ \\
\hline 2-Butanone (MEK) & $10 \mathrm{U}$ & $10 \mathrm{U}$ & $10 \mathrm{U}$ & $10 \mathrm{U}$ & $10 \mathrm{U}$ & $10 \mathrm{U}$ & $10 \mathrm{U}$ & $10 \mathrm{U}$ & $10 \mathrm{U}$ & $10 \mathrm{U}$ & $10 \mathrm{U}$ \\
\hline 2-Hexanone & $50 \mathrm{U}$ & $50 \mathrm{U}$ & $50 \mathrm{U}$ & $50 \mathrm{U}$ & $50 \mathrm{U}$ & $50 \mathrm{U}$ & $50 \mathrm{U}$ & $50 \mathrm{U}$ & $50 \mathrm{U}$ & $50 \mathrm{U}$ & $50 \mathrm{U}$ \\
\hline 4-Methyl-2-pentanone (MIBK) & $50 \mathrm{U}$ & $50 \mathrm{U}$ & $50 \mathrm{U}$ & $50 \mathrm{U}$ & $50 \mathrm{U}$ & $50 \mathrm{U}$ & $50 \mathrm{U}$ & $50 \mathrm{U}$ & $50 \mathrm{U}$ & $50 \mathrm{U}$ & $50 \mathrm{U}$ \\
\hline Acetone & $100 \mathrm{U}$ & $100 \mathrm{U}$ & $1.6 \mathrm{~J}$ & $100 \mathrm{U}$ & $100 \mathrm{U}$ & $100 \mathrm{U}$ & $100 \mathrm{U}$ & $100 \mathrm{U}$ & $100 \mathrm{U}$ & $100 \mathrm{U}$ & $100 \mathrm{U}$ \\
\hline Benzene & $5.0 \mathrm{U}$ & $5.0 \mathrm{U}$ & $5.0 \mathrm{U}$ & $5.0 \mathrm{U}$ & $5.0 \mathrm{U}$ & $5.0 \mathrm{U}$ & $5.0 \mathrm{U}$ & $5.0 \mathrm{U}$ & $5.0 \mathrm{U}$ & $5.0 \mathrm{U}$ & $0.90 \mathrm{~J}$ \\
\hline Bromodichloromethane & $5.0 \mathrm{U}$ & $5.0 \mathrm{U}$ & $5.0 \mathrm{U}$ & $5.0 \mathrm{U}$ & $5.0 \mathrm{U}$ & $5.0 \mathrm{U}$ & $5.0 \mathrm{U}$ & $5.0 \mathrm{U}$ & $5.0 \mathrm{U}$ & $5.0 \mathrm{U}$ & $5.0 \mathrm{U}$ \\
\hline Bromoform & $5.0 \mathrm{U}$ & $5.0 \mathrm{U}$ & $5.0 \mathrm{U}$ & $5.0 \mathrm{U}$ & $5.0 \mathrm{U}$ & $5.0 \mathrm{U}$ & $5.0 \mathrm{U}$ & $5.0 \mathrm{U}$ & $5.0 \mathrm{U}$ & $5.0 \mathrm{U}$ & $5.0 \mathrm{U}$ \\
\hline Bromomethane & $10 \mathrm{U}$ & $10 \mathrm{U}$ & $10 \mathrm{U}$ & $10 \mathrm{U}$ & $10 \mathrm{U}$ & $10 \mathrm{U}$ & $10 \mathrm{U}$ & $10 \mathrm{U}$ & $10 \mathrm{U}$ & $10 \mathrm{U}$ & $10 \mathrm{U}$ \\
\hline Carbon Disulfide & $5.0 \mathrm{U}$ & $5.0 \mathrm{U}$ & $5.0 \mathrm{U}$ & $5.0 \mathrm{U}$ & $5.0 \mathrm{U}$ & $5.0 \mathrm{U}$ & $5.0 \mathrm{U}$ & $5.0 \mathrm{U}$ & $5.0 \mathrm{U}$ & $5.0 \mathrm{U}$ & $5.0 \mathrm{U}$ \\
\hline Carbon Tetrachloride & $5.0 \mathrm{U}$ & $5.0 \mathrm{U}$ & $5.0 \mathrm{U}$ & $5.0 \mathrm{U}$ & $5.0 \mathrm{U}$ & $5.0 \mathrm{U}$ & $5.0 \mathrm{U}$ & $5.0 \mathrm{U}$ & $5.0 \mathrm{U}$ & $5.0 \mathrm{U}$ & $5.0 \mathrm{U}$ \\
\hline Chlorobenzene & $5.0 \mathrm{U}$ & $5.0 \mathrm{U}$ & $5.0 \mathrm{U}$ & $5.0 \mathrm{U}$ & $5.0 \mathrm{U}$ & $5.0 \mathrm{U}$ & $5.0 \mathrm{U}$ & $5.0 \mathrm{U}$ & $5.0 \mathrm{U}$ & $5.0 \mathrm{U}$ & $5.0 \mathrm{U}$ \\
\hline Chloroethane & $10 \mathrm{U}$ & $10 \mathrm{U}$ & $10 \mathrm{U}$ & $10 \mathrm{U}$ & $10 \mathrm{U}$ & $10 \mathrm{U}$ & $10 \mathrm{U}$ & $10 \mathrm{U}$ & $10 \mathrm{U}$ & $10 \mathrm{U}$ & $10 \mathrm{U}$ \\
\hline Chloroform & $5.0 \mathrm{U}$ & $5.0 \mathrm{U}$ & $5.0 \mathrm{U}$ & $5.0 \mathrm{U}$ & $5.0 \mathrm{U}$ & $5.0 \mathrm{U}$ & $5.0 \mathrm{U}$ & $5.0 \mathrm{U}$ & $5.0 \mathrm{U}$ & $5.0 \mathrm{U}$ & $5.0 \mathrm{U}$ \\
\hline Chloromethane & $10 \mathrm{U}$ & $10 \mathrm{U}$ & $10 \mathrm{U}$ & $10 \mathrm{U}$ & $10 \mathrm{U}$ & $10 \mathrm{U}$ & $10 \mathrm{U}$ & $10 \mathrm{U}$ & $10 \mathrm{U}$ & $10 \mathrm{U}$ & $10 \mathrm{U}$ \\
\hline cis-1,2-Dichloroethene & $5.0 \mathrm{U}$ & $5.0 \mathrm{U}$ & $5.0 \mathrm{U}$ & $5.0 \mathrm{U}$ & $5.0 \mathrm{U}$ & $5.0 \mathrm{U}$ & $5.0 \mathrm{U}$ & $5.0 \mathrm{U}$ & $5.0 \mathrm{U}$ & $5.0 \mathrm{U}$ & $5.0 \mathrm{U}$ \\
\hline cis-1,3-Dichloropropene & $5.0 \mathrm{U}$ & $5.0 \mathrm{U}$ & $5.0 \mathrm{U}$ & $5.0 \mathrm{U}$ & $5.0 \mathrm{U}$ & $5.0 \mathrm{U}$ & $5.0 \mathrm{U}$ & $5.0 \mathrm{U}$ & $5.0 \mathrm{U}$ & $5.0 \mathrm{U}$ & $5.0 \mathrm{U}$ \\
\hline Dibromochloromethane & $5.0 \mathrm{U}$ & $5.0 \mathrm{U}$ & $5.0 \mathrm{U}$ & $5.0 \mathrm{U}$ & $5.0 \mathrm{U}$ & $5.0 \mathrm{U}$ & $5.0 \mathrm{U}$ & $5.0 \mathrm{U}$ & $5.0 \mathrm{U}$ & $5.0 \mathrm{U}$ & $5.0 \mathrm{U}$ \\
\hline Ethylbenzene & $5.0 \mathrm{U}$ & $5.0 \mathrm{U}$ & $5.0 \mathrm{U}$ & $5.0 \mathrm{U}$ & $5.0 \mathrm{U}$ & $5.0 \mathrm{U}$ & $5.0 \mathrm{U}$ & $5.0 \mathrm{U}$ & $5.0 \mathrm{U}$ & $5.0 \mathrm{U}$ & $5.0 \mathrm{U}$ \\
\hline Methylene chloride & $5.0 \mathrm{U}$ & $5.0 \mathrm{U}$ & $5.0 \mathrm{U}$ & $5.0 \mathrm{U}$ & $5.0 \mathrm{U}$ & $5.0 \mathrm{U}$ & $5.0 \mathrm{U}$ & $5.0 \mathrm{U}$ & $5.0 \mathrm{U}$ & $5.0 \mathrm{U}$ & $5.0 \mathrm{U}$ \\
\hline Styrene & $5.0 \mathrm{U}$ & $5.0 \mathrm{U}$ & $5.0 \mathrm{U}$ & $5.0 \mathrm{U}$ & $5.0 \mathrm{U}$ & $5.0 \mathrm{U}$ & $5.0 \mathrm{U}$ & $5.0 \mathrm{U}$ & $5.0 \mathrm{U}$ & $5.0 \mathrm{U}$ & $5.0 \mathrm{U}$ \\
\hline Tetrachloroethene & $5.0 \mathrm{U}$ & $5.0 \mathrm{U}$ & $5.0 \mathrm{U}$ & $5.0 \mathrm{U}$ & $5.0 \mathrm{U}$ & $5.0 \mathrm{U}$ & $5.0 \mathrm{U}$ & $5.0 \mathrm{U}$ & $5.0 \mathrm{U}$ & $5.0 \mathrm{U}$ & $5.0 \mathrm{U}$ \\
\hline Toulene & $5.0 \mathrm{U}$ & $5.0 \mathrm{U}$ & $5.0 \mathrm{U}$ & $5.0 \mathrm{U}$ & $5.0 \mathrm{U}$ & $5.0 \mathrm{U}$ & $5.0 \mathrm{U}$ & $5.0 \mathrm{U}$ & $5.0 \mathrm{U}$ & $5.0 \mathrm{U}$ & $5.0 \mathrm{U}$ \\
\hline Total Xylenes & $5.0 \mathrm{U}$ & $5.0 \mathrm{U}$ & $5.0 \mathrm{U}$ & $5.0 \mathrm{U}$ & $5.0 \mathrm{U}$ & $5.0 \mathrm{U}$ & $5.0 \mathrm{U}$ & $5.0 \mathrm{U}$ & $5.0 \mathrm{U}$ & $5.0 \mathrm{U}$ & $5.0 \mathrm{U}$ \\
\hline trans-1,2-Dichloroethene & $5.0 \mathrm{U}$ & $5.0 \mathrm{U}$ & $5.0 \mathrm{U}$ & $5.0 \mathrm{U}$ & $5.0 \mathrm{U}$ & $5.0 \mathrm{U}$ & $5.0 \mathrm{U}$ & $5.0 \mathrm{U}$ & $5.0 \mathrm{U}$ & $5.0 \mathrm{U}$ & $5.0 \mathrm{U}$ \\
\hline trans-1,3-Dichloropropene & $5.0 \mathrm{U}$ & $5.0 \mathrm{U}$ & $5.0 \mathrm{U}$ & $5.0 \mathrm{U}$ & $5.0 \mathrm{U}$ & $5.0 \mathrm{U}$ & $5.0 \mathrm{U}$ & $5.0 \mathrm{U}$ & $5.0 \mathrm{U}$ & $5.0 \mathrm{U}$ & $5.0 \mathrm{U}$ \\
\hline Trichloroethene & $5.0 \mathrm{U}$ & $5.0 \mathrm{U}$ & $5.0 \mathrm{U}$ & $5.0 \mathrm{U}$ & $5.0 \mathrm{U}$ & $5.0 \mathrm{U}$ & $5.0 \mathrm{U}$ & $5.0 \mathrm{U}$ & $5.0 \mathrm{U}$ & $5.0 \mathrm{U}$ & $5.0 \mathrm{U}$ \\
\hline Vinyl chloride & $10 \mathrm{U}$ & $10 \mathrm{U}$ & $10 \mathrm{U}$ & $10 \mathrm{U}$ & $10 \mathrm{U}$ & $10 \mathrm{U}$ & $10 \mathrm{U}$ & $10 \mathrm{U}$ & $10 \mathrm{U}$ & $10 \mathrm{U}$ & $10 \mathrm{U}$ \\
\hline
\end{tabular}

J - Quantitative estimate. U - Not detected. 
TABLE 18 (continued)

Results of Analysis - Groundwater Samples

Main Plateau (Continued) - Volatile Organic Compounds Constituents (UG/L)

\begin{tabular}{|c|c|c|c|c|c|c|c|c|}
\hline \multirow{3}{*}{ Constituent } & \multicolumn{6}{|c|}{ Well Number and Sample Date } & \multirow{2}{*}{\multicolumn{2}{|c|}{ MPW-12 }} \\
\hline & \multicolumn{2}{|c|}{ MPW-9 } & \multicolumn{2}{|c|}{ MPW-10 } & \multicolumn{2}{|c|}{ MPW-11 } & & \\
\hline & $4 / 28 / 98$ & $9 / 30 / 98$ & $4 / 28 / 98$ & 9/30/98 & $4 / 28 / 98$ & 9/30/98 & \multicolumn{2}{|c|}{$4 / 28 / 98 \quad 9 / 30 / 98$} \\
\hline 1,1,1-Trichloroethane & $5.0 \mathrm{U}$ & $5.0 \mathrm{U}$ & $5.0 \mathrm{U}$ & $5.0 \mathrm{U}$ & $5.0 \mathrm{U}$ & $5.0 \mathrm{U}$ & $5.0 \mathrm{U}$ & $5.0 \mathrm{U}$ \\
\hline 1,1,2,2-Tetrachloroethane & $5.0 \mathrm{U}$ & $5.0 \mathrm{U}$ & $5.0 \mathrm{U}$ & $5.0 \mathrm{U}$ & $5.0 \mathrm{U}$ & $5.0 \mathrm{U}$ & $5.0 \mathrm{U}$ & $5.0 \mathrm{U}$ \\
\hline 1,1,2-Trichloroethane & $5.0 \mathrm{U}$ & $5.0 \mathrm{U}$ & $5.0 \mathrm{U}$ & $5.0 \mathrm{U}$ & $5.0 \mathrm{U}$ & $5.0 \mathrm{U}$ & $5.0 \mathrm{U}$ & $5.0 \mathrm{U}$ \\
\hline 1,1-Dichloroethane & $5.0 \mathrm{U}$ & $5.0 \mathrm{U}$ & $5.0 \mathrm{U}$ & $5.0 \mathrm{U}$ & $5.0 \mathrm{U}$ & $5.0 \mathrm{U}$ & $5.0 \mathrm{U}$ & $5.0 \mathrm{U}$ \\
\hline 1,1-Dichloroethene & $5.0 \mathrm{U}$ & $5.0 \mathrm{U}$ & $5.0 \mathrm{U}$ & $5.0 \mathrm{U}$ & $5.0 \mathrm{U}$ & $5.0 \mathrm{U}$ & $5.0 \mathrm{U}$ & $5.0 \mathrm{U}$ \\
\hline 1,2-Dichloroethane & $5.0 \mathrm{U}$ & $5.0 \mathrm{U}$ & $5.0 \mathrm{U}$ & $5.0 \mathrm{U}$ & $5.0 \mathrm{U}$ & $5.0 \mathrm{U}$ & $5.0 \mathrm{U}$ & $5.0 \mathrm{U}$ \\
\hline 1,2-Dichloropropane & $5.0 \mathrm{U}$ & $5.0 \mathrm{U}$ & $5.0 \mathrm{U}$ & $5.0 \mathrm{U}$ & $5.0 \mathrm{U}$ & $5.0 \mathrm{U}$ & $5.0 \mathrm{U}$ & $5.0 \mathrm{U}$ \\
\hline 2-Butanone (MEK) & $10 \mathrm{U}$ & $10 \mathrm{U}$ & $10 \mathrm{U}$ & $10 \mathrm{U}$ & $10 \mathrm{U}$ & $10 \mathrm{U}$ & $10 \mathrm{U}$ & $10 \mathrm{U}$ \\
\hline 2-Hexanone & $50 \mathrm{U}$ & $50 \mathrm{U}$ & $50 \mathrm{U}$ & $50 \mathrm{U}$ & $50 \mathrm{U}$ & $50 \mathrm{U}$ & $50 \mathrm{U}$ & $50 \mathrm{U}$ \\
\hline 4-Methyl-2-pentanone (MIBK) & $50 \mathrm{U}$ & $50 \mathrm{U}$ & $50 \mathrm{U}$ & $50 \mathrm{U}$ & $50 \mathrm{U}$ & $50 \mathrm{U}$ & $50 \mathrm{U}$ & $50 \mathrm{U}$ \\
\hline Acetone & $100 \mathrm{U}$ & $100 \mathrm{U}$ & $100 \mathrm{U}$ & $100 \mathrm{U}$ & $100 \mathrm{U}$ & $100 \mathrm{U}$ & $100 \mathrm{U}$ & $100 \mathrm{U}$ \\
\hline Benzene & $5.0 \mathrm{U}$ & $5.0 \mathrm{U}$ & $5.0 \mathrm{U}$ & $5.0 \mathrm{U}$ & $5.0 \mathrm{U}$ & $5.0 \mathrm{U}$ & $5.0 \mathrm{U}$ & $5.0 \mathrm{U}$ \\
\hline Bromodichloromethane & $5.0 \mathrm{U}$ & $5.0 \mathrm{U}$ & $5.0 \mathrm{U}$ & $5.0 \mathrm{U}$ & $5.0 \mathrm{U}$ & $5.0 \mathrm{U}$ & $5.0 \mathrm{U}$ & $5.0 \mathrm{U}$ \\
\hline Bromoform & $5.0 \mathrm{U}$ & $5.0 \mathrm{U}$ & $5.0 \mathrm{U}$ & $5.0 \mathrm{U}$ & $5.0 \mathrm{U}$ & $5.0 \mathrm{U}$ & $5.0 \mathrm{U}$ & $5.0 \mathrm{U}$ \\
\hline Bromomethane & $10 \mathrm{U}$ & $10 \mathrm{U}$ & $10 \mathrm{U}$ & $10 \mathrm{U}$ & $10 \mathrm{U}$ & $10 \mathrm{U}$ & $10 \mathrm{U}$ & $10 \mathrm{U}$ \\
\hline Carbon Disulfide & $5.0 \mathrm{U}$ & $5.0 \mathrm{U}$ & $5.0 \mathrm{U}$ & $5.0 \mathrm{U}$ & $5.0 \mathrm{U}$ & $5.0 \mathrm{U}$ & $5.0 \mathrm{U}$ & $5.0 \mathrm{U}$ \\
\hline Carbon Tetrachloride & $5.0 \mathrm{U}$ & $5.0 \mathrm{U}$ & $5.0 \mathrm{U}$ & $5.0 \mathrm{U}$ & $5.0 \mathrm{U}$ & $5.0 \mathrm{U}$ & $5.0 \mathrm{U}$ & $5.0 \mathrm{U}$ \\
\hline Chlorobenzene & $5.0 \mathrm{U}$ & $5.0 \mathrm{U}$ & $5.0 \mathrm{U}$ & $5.0 \mathrm{U}$ & $5.0 \mathrm{U}$ & $5.0 \mathrm{U}$ & $5.0 \mathrm{U}$ & $5.0 \mathrm{U}$ \\
\hline Chloroethane & $10 \mathrm{U}$ & $10 \mathrm{U}$ & $10 \mathrm{U}$ & $10 \mathrm{U}$ & $10 \mathrm{U}$ & $10 \mathrm{U}$ & $10 \mathrm{U}$ & $10 \mathrm{U}$ \\
\hline Chloroform & $5.0 \mathrm{U}$ & $5.0 \mathrm{U}$ & $5.0 \mathrm{U}$ & $5.0 \mathrm{U}$ & $5.0 \mathrm{U}$ & $5.0 \mathrm{U}$ & $3.3 \mathrm{~J}$ & $5.0 \mathrm{U}$ \\
\hline Chloromethane & $10 \mathrm{U}$ & $10 \mathrm{U}$ & $10 \mathrm{U}$ & $10 \mathrm{U}$ & $10 \mathrm{U}$ & $10 \mathrm{U}$ & $10 \mathrm{U}$ & $10 \mathrm{U}$ \\
\hline cis-1,2-Dchloroethene & $5.0 \mathrm{U}$ & $5.0 \mathrm{U}$ & $5.0 \mathrm{U}$ & $5.0 \mathrm{U}$ & $5.0 \mathrm{U}$ & $5.0 \mathrm{U}$ & $5.0 \mathrm{U}$ & $5.0 \mathrm{U}$ \\
\hline cis-1,3-Dichloropropene & $5.0 \mathrm{U}$ & $5.0 \mathrm{U}$ & $5.0 \mathrm{U}$ & $5.0 \mathrm{U}$ & $5.0 \mathrm{U}$ & $5.0 \mathrm{U}$ & $5.0 \mathrm{U}$ & $5.0 \mathrm{U}$ \\
\hline Dibromochloromethane & $5.0 \mathrm{U}$ & $5.0 \mathrm{U}$ & $5.0 \mathrm{U}$ & $5.0 \mathrm{U}$ & $5.0 \mathrm{U}$ & $5.0 \mathrm{U}$ & $5.0 \mathrm{U}$ & $5.0 \mathrm{U}$ \\
\hline Ethylbenzene & $5.0 \mathrm{U}$ & $5.0 \mathrm{U}$ & $5.0 \mathrm{U}$ & $5.0 \mathrm{U}$ & $5.0 \mathrm{U}$ & $5.0 \mathrm{U}$ & $5.0 \mathrm{U}$ & $5.0 \mathrm{U}$ \\
\hline Methylene chloride & $5.0 \mathrm{U}$ & $5.0 \mathrm{U}$ & $5.0 \mathrm{U}$ & $5.0 \mathrm{U}$ & $5.0 \mathrm{U}$ & $5.0 \mathrm{U}$ & $5.0 \mathrm{U}$ & $5.0 \mathrm{U}$ \\
\hline Styrene & $5.0 \mathrm{U}$ & $5.0 \mathrm{U}$ & $5.0 \mathrm{U}$ & $5.0 \mathrm{U}$ & $5.0 \mathrm{U}$ & $5.0 \mathrm{U}$ & $5.0 \mathrm{U}$ & $5.0 \mathrm{U}$ \\
\hline Tetrachloroethene & $5.0 \mathrm{U}$ & $5.0 \mathrm{U}$ & $5.0 \mathrm{U}$ & $5.0 \mathrm{U}$ & $5.0 \mathrm{U}$ & $5.0 \mathrm{U}$ & $5.0 \mathrm{U}$ & $5.0 \mathrm{U}$ \\
\hline Toulene & $5.0 \mathrm{U}$ & $5.0 \mathrm{U}$ & $5.0 \mathrm{U}$ & $5.0 \mathrm{U}$ & $5.0 \mathrm{U}$ & $5.0 \mathrm{U}$ & $5.0 \mathrm{U}$ & $5.0 \mathrm{U}$ \\
\hline Total Xylenes & $5.0 \mathrm{U}$ & $5.0 \mathrm{U}$ & $5.0 \mathrm{U}$ & $5.0 \mathrm{U}$ & $5.0 \mathrm{U}$ & $5.0 \mathrm{U}$ & $5.0 \mathrm{U}$ & $5.0 \mathrm{U}$ \\
\hline trans-1,2-Dichloroethene & $5.0 \mathrm{U}$ & $5.0 \mathrm{U}$ & $5.0 \mathrm{U}$ & $5.0 \mathrm{U}$ & $5.0 \mathrm{U}$ & $5.0 \mathrm{U}$ & $5.0 \mathrm{U}$ & $5.0 \mathrm{U}$ \\
\hline trans-1,3-Dichloropropene & $5.0 \mathrm{U}$ & $5.0 \mathrm{U}$ & $5.0 \mathrm{U}$ & $5.0 \mathrm{U}$ & $5.0 \mathrm{U}$ & $5.0 \mathrm{U}$ & $5.0 \mathrm{U}$ & $5.0 \mathrm{U}$ \\
\hline Trichloroethene & $5.0 \mathrm{U}$ & $5.0 \mathrm{U}$ & $5.0 \mathrm{U}$ & $5.0 \mathrm{U}$ & $5.0 \mathrm{U}$ & $5.0 \mathrm{U}$ & $5.0 \mathrm{U}$ & $5.0 \mathrm{U}$ \\
\hline Vinyl chloride & $10 \mathrm{U}$ & $10 \mathrm{U}$ & $10 \mathrm{U}$ & $10 \mathrm{U}$ & $10 \mathrm{U}$ & $10 \mathrm{U}$ & $10 \mathrm{U}$ & $10 \mathrm{U}$ \\
\hline
\end{tabular}


TABLE 19

FETC-PGH 1998 Groundwater Detection Monitoring Program

Results of Analysis - Groundwater Samples

Valley Fill - Volatile Organic Compounds Constituents (UG/L)

\begin{tabular}{|c|c|c|c|c|c|c|c|c|c|c|c|}
\hline \multirow[t]{2}{*}{ Constituent } & \multicolumn{9}{|c|}{$\begin{array}{l}\text { Well Number and Sample Date } \\
\text { VFW-10 }\end{array}$} & \multicolumn{2}{|c|}{ VFW-14 } \\
\hline & $4 / 28 / 98$ & $9 / 29 / 98$ & $9 / 29 / 98$ & $4 / 28 / 98$ & $9 / 30 / 98$ & $4 / 29 / 98$ & $9 / 30 / 98$ & $4 / 28 / 98$ & $9 / 30 / 98$ & $4 / 28 / 98$ & $9 / 30 / 98$ \\
\hline 1,1,1-Trichloroethane & $5.0 \mathrm{U}$ & $5.0 \mathrm{U}$ & $5.0 \mathrm{U}$ & $5.0 \mathrm{U}$ & $5.0 \mathrm{U}$ & $5.0 \mathrm{U}$ & $5.0 \mathrm{U}$ & $5.0 \mathrm{U}$ & $5.0 \mathrm{U}$ & $5.0 \mathrm{U}$ & $5.0 \mathrm{U}$ \\
\hline 1,1,2,2-Tetrachloroethane & $5.0 \mathrm{U}$ & $5.0 \mathrm{U}$ & $5.0 \mathrm{U}$ & $5.0 \mathrm{U}$ & $5.0 \mathrm{U}$ & $5.0 \mathrm{U}$ & $5.0 \mathrm{U}$ & $5.0 \mathrm{U}$ & $5.0 \mathrm{U}$ & $5.0 \mathrm{U}$ & $5.0 \mathrm{U}$ \\
\hline 1,1,2-Trichloroethane & $5.0 \mathrm{U}$ & $5.0 \mathrm{U}$ & $5.0 \mathrm{U}$ & $5.0 \mathrm{U}$ & $5.0 \mathrm{U}$ & $5.0 \mathrm{U}$ & $5.0 \mathrm{U}$ & $5.0 \mathrm{U}$ & $5.0 \mathrm{U}$ & $5.0 \mathrm{U}$ & $5.0 \mathrm{U}$ \\
\hline 1,1-Dichloroethane & $5.0 \mathrm{U}$ & $5.0 \mathrm{U}$ & $5.0 \mathrm{U}$ & $5.0 \mathrm{U}$ & $5.0 \mathrm{U}$ & $5.0 \mathrm{U}$ & $5.0 \mathrm{U}$ & $5.0 \mathrm{U}$ & $5.0 \mathrm{U}$ & $5.0 \mathrm{U}$ & $5.0 \mathrm{U}$ \\
\hline 1,1-Dichloroethene & $5.0 \mathrm{U}$ & $5.0 \mathrm{U}$ & $5.0 \mathrm{U}$ & $5.0 \mathrm{U}$ & $5.0 \mathrm{U}$ & $5.0 \mathrm{U}$ & $5.0 \mathrm{U}$ & $5.0 \mathrm{U}$ & $5.0 \mathrm{U}$ & $5.0 \mathrm{U}$ & $5.0 \mathrm{U}$ \\
\hline 1,2-Dichloroethane & $5.0 \mathrm{U}$ & $5.0 \mathrm{U}$ & $5.0 \mathrm{U}$ & $5.0 \mathrm{U}$ & $5.0 \mathrm{U}$ & $5.0 \mathrm{U}$ & $5.0 \mathrm{U}$ & $5.0 \mathrm{U}$ & $5.0 \mathrm{U}$ & $5.0 \mathrm{U}$ & $5.0 \mathrm{U}$ \\
\hline 1,2-Dichloropropane & $5.0 \mathrm{U}$ & $5.0 \mathrm{U}$ & $5.0 \mathrm{U}$ & $5.0 \mathrm{U}$ & $5.0 \mathrm{U}$ & $5.0 \mathrm{U}$ & $5.0 \mathrm{U}$ & $5.0 \mathrm{U}$ & $5.0 \mathrm{U}$ & $5.0 \mathrm{U}$ & $5.0 \mathrm{U}$ \\
\hline 2-Butanone (MEK) & $10 \mathrm{U}$ & $10 \mathrm{U}$ & $10 \mathrm{U}$ & $10 \mathrm{U}$ & $10 \mathrm{U}$ & $10 \mathrm{U}$ & $10 \mathrm{U}$ & $10 \mathrm{U}$ & $10 \mathrm{U}$ & $10 \mathrm{U}$ & $10 \mathrm{U}$ \\
\hline 2-Hexanone & $50 \mathrm{U}$ & $50 \mathrm{U}$ & $50 \mathrm{U}$ & $50 \mathrm{U}$ & $50 \mathrm{U}$ & $50 \mathrm{U}$ & $50 \mathrm{U}$ & $50 \mathrm{U}$ & $50 \mathrm{U}$ & $50 \mathrm{U}$ & $50 \mathrm{U}$ \\
\hline 4-Methyl-2-pentanone (MIBK) & $50 \mathrm{U}$ & $50 \mathrm{U}$ & $50 \mathrm{U}$ & $50 \mathrm{U}$ & $50 \mathrm{U}$ & $50 \mathrm{U}$ & $50 \mathrm{U}$ & $50 \mathrm{U}$ & $50 \mathrm{U}$ & $50 \mathrm{U}$ & $50 \mathrm{U}$ \\
\hline Acetone & $100 \mathrm{U}$ & $100 \mathrm{U}$ & $100 \mathrm{U}$ & $100 \mathrm{U}$ & $100 \mathrm{U}$ & $100 \mathrm{U}$ & $100 \mathrm{U}$ & $100 \mathrm{U}$ & $100 \mathrm{U}$ & $100 \mathrm{U}$ & $100 \mathrm{U}$ \\
\hline Benzene & $5.0 \mathrm{U}$ & $5.0 \mathrm{U}$ & $5.0 \mathrm{U}$ & $5.0 \mathrm{U}$ & $5.0 \mathrm{U}$ & $5.0 \mathrm{U}$ & $5.0 \mathrm{U}$ & $5.0 \mathrm{U}$ & $5.0 \mathrm{U}$ & $5.0 \mathrm{U}$ & $5.0 \mathrm{U}$ \\
\hline Bromodichloromethane & $5.0 \mathrm{U}$ & $5.0 \mathrm{U}$ & $5.0 \mathrm{U}$ & $5.0 \mathrm{U}$ & $5.0 \mathrm{U}$ & $5.0 \mathrm{U}$ & $5.0 \mathrm{U}$ & $5.0 \mathrm{U}$ & $5.0 \mathrm{U}$ & $5.0 \mathrm{U}$ & $5.0 \mathrm{U}$ \\
\hline Bromoform & $5.0 \mathrm{U}$ & $5.0 \mathrm{U}$ & $5.0 \mathrm{U}$ & $5.0 \mathrm{U}$ & $5.0 \mathrm{U}$ & $5.0 \mathrm{U}$ & $5.0 \mathrm{U}$ & $5.0 \mathrm{U}$ & $5.0 \mathrm{U}$ & $5.0 \mathrm{U}$ & $5.0 \mathrm{U}$ \\
\hline Bromomethane & $10 \mathrm{U}$ & $10 \mathrm{U}$ & $10 \mathrm{U}$ & $10 \mathrm{U}$ & $10 \mathrm{U}$ & $10 \mathrm{U}$ & $10 \mathrm{U}$ & $10 \mathrm{U}$ & $10 \mathrm{U}$ & $10 \mathrm{U}$ & $10 \mathrm{U}$ \\
\hline Carbon Disulfide & $5.0 \mathrm{U}$ & $5.0 \mathrm{U}$ & $5.0 \mathrm{U}$ & $5.0 \mathrm{U}$ & $5.0 \mathrm{U}$ & $5.0 \mathrm{U}$ & $5.0 \mathrm{U}$ & $5.0 \mathrm{U}$ & $5.0 \mathrm{U}$ & $5.0 \mathrm{U}$ & $5.0 \mathrm{U}$ \\
\hline Carbon Tetrachloride & $5.0 \mathrm{U}$ & $5.0 \mathrm{U}$ & $5.0 \mathrm{U}$ & $5.0 \mathrm{U}$ & $5.0 \mathrm{U}$ & $5.0 \mathrm{U}$ & $5.0 \mathrm{U}$ & $5.0 \mathrm{U}$ & $5.0 \mathrm{U}$ & $5.0 \mathrm{U}$ & $5.0 \mathrm{U}$ \\
\hline Chlorobenzene & $5.0 \mathrm{U}$ & $5.0 \mathrm{U}$ & $5.0 \mathrm{U}$ & $5.0 \mathrm{U}$ & $5.0 \mathrm{U}$ & $5.0 \mathrm{U}$ & $5.0 \mathrm{U}$ & $5.0 \mathrm{U}$ & $5.0 \mathrm{U}$ & $5.0 \mathrm{U}$ & $5.0 \mathrm{U}$ \\
\hline Chloroethane & $10 \mathrm{U}$ & $10 \mathrm{U}$ & $10 \mathrm{U}$ & $10 \mathrm{U}$ & $10 \mathrm{U}$ & $10 \mathrm{U}$ & $10 \mathrm{U}$ & $10 \mathrm{U}$ & $10 \mathrm{U}$ & $10 \mathrm{U}$ & $10 \mathrm{U}$ \\
\hline Chloroform & $5.0 \mathrm{U}$ & $5.0 \mathrm{U}$ & $5.0 \mathrm{U}$ & $5.0 \mathrm{U}$ & $5.0 \mathrm{U}$ & $5.0 \mathrm{U}$ & $5.0 \mathrm{U}$ & $5.0 \mathrm{U}$ & $5.0 \mathrm{U}$ & $5.0 \mathrm{U}$ & $5.0 \mathrm{U}$ \\
\hline Chloromethane & $10 \mathrm{U}$ & $10 \mathrm{U}$ & $10 \mathrm{U}$ & $10 \mathrm{U}$ & $10 \mathrm{U}$ & $10 \mathrm{U}$ & $10 \mathrm{U}$ & $10 \mathrm{U}$ & $10 \mathrm{U}$ & $10 \mathrm{U}$ & $10 \mathrm{U}$ \\
\hline cis-1,2-Dichloroethene & $5.0 \mathrm{U}$ & $0.90 \mathrm{~J}$ & $0.90 \mathrm{~J}$ & $4.4 \mathrm{~J}$ & 10 & $5.0 \mathrm{U}$ & $5.0 \mathrm{U}$ & $5.0 \mathrm{U}$ & $5.0 \mathrm{U}$ & $5.0 \mathrm{U}$ & $5.0 \mathrm{U}$ \\
\hline cis-1,3-Dichloropropene & $5.0 \mathrm{U}$ & $5.0 \mathrm{U}$ & $5.0 \mathrm{U}$ & $5.0 \mathrm{U}$ & $5.0 \mathrm{U}$ & $5.0 \mathrm{U}$ & $5.0 \mathrm{U}$ & $5.0 \mathrm{U}$ & $5.0 \mathrm{U}$ & $5.0 \mathrm{U}$ & $5.0 \mathrm{U}$ \\
\hline Dibromochloromethane & $5.0 \mathrm{U}$ & $5.0 \mathrm{U}$ & $5.0 \mathrm{U}$ & $5.0 \mathrm{U}$ & $5.0 \mathrm{U}$ & $5.0 \mathrm{U}$ & $5.0 \mathrm{U}$ & $5.0 \mathrm{U}$ & $5.0 \mathrm{U}$ & $5.0 \mathrm{U}$ & $5.0 \mathrm{U}$ \\
\hline Ethylbenzene & $5.0 \mathrm{U}$ & $5.0 \mathrm{U}$ & $5.0 \mathrm{U}$ & $5.0 \mathrm{U}$ & $5.0 \mathrm{U}$ & $5.0 \mathrm{U}$ & $5.0 \mathrm{U}$ & $5.0 \mathrm{U}$ & $5.0 \mathrm{U}$ & $5.0 \mathrm{U}$ & $5.0 \mathrm{U}$ \\
\hline Methylene chloride & $5.0 \mathrm{U}$ & $5.0 \mathrm{U}$ & $5.0 \mathrm{U}$ & $5.0 \mathrm{U}$ & $5.0 \mathrm{U}$ & $5.0 \mathrm{U}$ & $5.0 \mathrm{U}$ & $5.0 \mathrm{U}$ & $5.0 \mathrm{U}$ & $5.0 \mathrm{U}$ & $5.0 \mathrm{U}$ \\
\hline Styrene & $5.0 \mathrm{U}$ & $5.0 \mathrm{U}$ & $5.0 \mathrm{U}$ & $5.0 \mathrm{U}$ & $5.0 \mathrm{U}$ & $5.0 \mathrm{U}$ & $5.0 \mathrm{U}$ & $5.0 \mathrm{U}$ & $5.0 \mathrm{U}$ & $5.0 \mathrm{U}$ & $5.0 \mathrm{U}$ \\
\hline Tetrachloroethene & $5.0 \mathrm{U}$ & $5.0 \mathrm{U}$ & $5.0 \mathrm{U}$ & 24 & 36 & $5.0 \mathrm{U}$ & $5.0 \mathrm{U}$ & $5.0 \mathrm{U}$ & $5.0 \mathrm{U}$ & $5.0 \mathrm{U}$ & $5.0 \mathrm{U}$ \\
\hline Toulene & $5.0 \mathrm{U}$ & $5.0 \mathrm{U}$ & $5.0 \mathrm{U}$ & $5.0 \mathrm{U}$ & $5.0 \mathrm{U}$ & $5.0 \mathrm{U}$ & $5.0 \mathrm{U}$ & $5.0 \mathrm{U}$ & $5.0 \mathrm{U}$ & $5.0 \mathrm{U}$ & $5.0 \mathrm{U}$ \\
\hline Total Xylenes & $5.0 \mathrm{U}$ & $5.0 \mathrm{U}$ & $5.0 \mathrm{U}$ & $5.0 \mathrm{U}$ & $5.0 \mathrm{U}$ & $5.0 \mathrm{U}$ & $5.0 \mathrm{U}$ & $5.0 \mathrm{U}$ & $5.0 \mathrm{U}$ & $5.0 \mathrm{U}$ & $5.0 \mathrm{U}$ \\
\hline trans-1,2-Dichloroethene & $5.0 \mathrm{U}$ & $5.0 \mathrm{U}$ & $5.0 \mathrm{U}$ & $5.0 \mathrm{U}$ & $5.0 \mathrm{U}$ & $5.0 \mathrm{U}$ & $5.0 \mathrm{U}$ & $5.0 \mathrm{U}$ & $5.0 \mathrm{U}$ & $5.0 \mathrm{U}$ & $5.0 \mathrm{U}$ \\
\hline trans-1,3-Dichloropropene & $5.0 \mathrm{U}$ & $5.0 \mathrm{U}$ & $5.0 \mathrm{U}$ & $5.0 \mathrm{U}$ & $5.0 \mathrm{U}$ & $5.0 \mathrm{U}$ & $5.0 \mathrm{U}$ & $5.0 \mathrm{U}$ & $5.0 \mathrm{U}$ & $5.0 \mathrm{U}$ & $5.0 \mathrm{U}$ \\
\hline Trichloroethene & $5.0 \mathrm{U}$ & $5.0 \mathrm{U}$ & $5.0 \mathrm{U}$ & $5.0 \mathrm{U}$ & $1.0 \mathrm{~J}$ & $5.0 \mathrm{U}$ & $5.0 \mathrm{U}$ & $5.0 \mathrm{U}$ & $5.0 \mathrm{U}$ & $5.0 \mathrm{U}$ & $5.0 \mathrm{U}$ \\
\hline Vinyl chloride & $10 \mathrm{U}$ & $10 \mathrm{U}$ & $10 \mathrm{U}$ & $10 \mathrm{U}$ & $10 \mathrm{U}$ & $10 \mathrm{U}$ & $10 \mathrm{U}$ & $10 \mathrm{U}$ & $10 \mathrm{U}$ & $10 \mathrm{U}$ & $10 \mathrm{U}$ \\
\hline
\end{tabular}

J - Quantitative estimate. U - Not detected. 
TABLE 20

April, 1998 FETC-MGN Groundwater Data for "Morgantown Aquifer"

\begin{tabular}{|l|c|c|c|c|}
\hline \multicolumn{5}{|c|}{ Sample Location } \\
\hline Parameter & D1M & D2M & D3M & D4M \\
\hline pH (s.u) & 6.55 & 9.45 & 8.55 & 7.4 \\
\hline Specific Conductance (uMhos) & 319 & 560 & 453 & 272 \\
\hline Temperature (C) & 15.5 & 13.8 & 14.3 & 13.6 \\
\hline Arsenic (total, mg/L) & 0.009 & 0.006 & $\mathrm{ND}$ & $\mathrm{ND}$ \\
\hline Barium (total, $\mathrm{mg} / \mathrm{L})$ & 0.19 & 0.17 & 0.87 & 0.26 \\
\hline Cadmium (total, mg/L) & $\mathrm{ND}$ & $\mathrm{ND}$ & $\mathrm{ND}$ & $\mathrm{ND}$ \\
\hline Chromium (total, $\mathrm{mg} / \mathrm{L})$ & $\mathrm{ND}$ & $\mathrm{ND}$ & $\mathrm{ND}$ & $\mathrm{ND}$ \\
\hline Lead (total, $\mathrm{mg} / \mathrm{L})$ & $\mathrm{ND}$ & 0.009 & $\mathrm{ND}$ & 0.005 \\
\hline Mercury (total, $\mathrm{mg} / \mathrm{L})$ & $\mathrm{ND}$ & $\mathrm{ND}$ & $\mathrm{ND}$ & $\mathrm{ND}$ \\
\hline Selenium (total, $\mathrm{mg} / \mathrm{L})$ & $\mathrm{ND}$ & $\mathrm{ND}$ & $\mathrm{ND}$ & $\mathrm{ND}$ \\
\hline Silver (total, $\mathrm{mg} / \mathrm{L})$ & $\mathrm{ND}$ & $\mathrm{ND}$ & $\mathrm{ND}$ & $\mathrm{ND}$ \\
\hline Iron (total, $\mathrm{mg} / \mathrm{L})$ & 12 & 9.7 & 0.56 & 0.62 \\
\hline Manganese (total, $\mathrm{mg} / \mathrm{L})$ & 1.2 & 0.33 & 0.061 & 1 \\
\hline Sodium (total, $\mathrm{mg} / \mathrm{L})$ & 6.9 & 130 & 39 & 17 \\
\hline Vanadium (total, $\mathrm{mg} / \mathrm{L})$ & $\mathrm{ND}$ & $\mathrm{ND}$ & $\mathrm{ND}$ & $\mathrm{ND}$ \\
\hline Benzene (mg/L) & $\mathrm{ND}$ & $\mathrm{ND}$ & $\mathrm{ND}$ & $\mathrm{ND}$ \\
\hline Toluene (mg/L) & $\mathrm{ND}$ & $\mathrm{ND}$ & $\mathrm{ND}$ & $\mathrm{ND}$ \\
\hline Ethylbenzene (mg/L) & $\mathrm{ND}$ & $\mathrm{ND}$ & $\mathrm{ND}$ & $\mathrm{ND}$ \\
\hline Total Xylenes (mg/L) & $\mathrm{ND}$ & $\mathrm{ND}$ & $\mathrm{ND}$ & $\mathrm{ND}$ \\
\hline Total Organic Halides (mg/L) & $\mathrm{ND}$ & $\mathrm{ND}$ & $\mathrm{ND}$ & $\mathrm{ND}$ \\
\hline Chloride (mg/L) & 12 & 3 & 3 & 43 \\
\hline Sulfate (mg/L) & 29 & 6 & 16 & 9 \\
\hline Nitrate Nitrogen (mg/L) & 0.14 & 0.23 & $\mathrm{ND}$ & $\mathrm{ND}$ \\
\hline Fluoride (mg/L) & 0.05 & 0.66 & 0.17 & 0.15 \\
\hline Total Recoverable Phenolics (mg/L) & $\mathrm{ND}$ & $\mathrm{ND}$ & $\mathrm{ND}$ & $\mathrm{ND}$ \\
\hline Cyanide (total. $\mathrm{mg} / \mathrm{L})$ & $\mathrm{ND}$ & $\mathrm{ND}$ & $\mathrm{ND}$ & $\mathrm{ND}$ \\
\hline Total Organic Carbon (mg/L) & 2 & 2 & 1 & 1 \\
\hline Naphthalene (ug/L) & $\mathrm{ND}$ & $\mathrm{ND}$ & $\mathrm{ND}$ & $\mathrm{ND}$ \\
\hline Other Semivolatiles & $\mathrm{ND}$ & $\mathrm{ND}$ & $\mathrm{ND}$ & $\mathrm{ND}$ \\
\hline
\end{tabular}


TABLE 21

FETC-MGN

April 1998 Groundwater Data for "A Aquifer"

\begin{tabular}{|c|c|c|c|c|c|c|c|c|c|c|c|c|c|}
\hline \multirow[b]{2}{*}{ Parameter } & \multicolumn{9}{|c|}{ Sample Location } & \multirow[b]{2}{*}{$\mathrm{L}$} & \multirow[b]{2}{*}{$\mathrm{M}$} & \multirow[b]{2}{*}{$\mathrm{N}$} & \multirow[b]{2}{*}{ GAS-4 } \\
\hline & $\mathrm{A}$ & $\mathrm{B}$ & SP1-A & SP4-A & SP8-A & SP9-A & I & $\mathrm{J}$ & $\mathrm{K}$ & & & & \\
\hline $\mathrm{pH}(\mathrm{s} . \mathrm{u})$ & 6.66 & 7.4 & 7.29 & 6.59 & 7.15 & 6.7 & 6.24 & 5.89 & 5.4 & 5.78 & 5.84 & 5.71 & 7.14 \\
\hline Specific Conductance (uMhos) & 327 & 396 & 275 & 251 & 325 & 1138 & 684 & 641 & 613 & 645 & 368 & 623 & 238 \\
\hline Temperature $(\mathrm{C})$ & 14.4 & 14.8 & 14.3 & 15.1 & 15 & 15 & 15.9 & 15 & 13.3 & 13.7 & 12.1 & 14.8 & 17.4 \\
\hline Arsenic (total, mg/L) & ND & 0.006 & ND & ND & ND & ND & 0.007 & ND & ND & ND & ND & ND & 0.012 \\
\hline Barium (total, mg/L) & 0.39 & 0.24 & 0.15 & 0.048 & 0.29 & 0.31 & 0.37 & 1 & 0.078 & 0.079 & 0.04 & 0.22 & 0.26 \\
\hline Cadmium (total, mg/L) & ND & ND & ND & ND & ND & 0.0009 & ND & 0.0008 & 0.0019 & 0.0021 & 0.0012 & 0.0011 & ND \\
\hline Chromium (total, mg/L) & ND & ND & ND & ND & ND & 0.026 & ND & ND & ND & ND & ND & ND & ND \\
\hline Lead (total, mg/L) & ND & ND & ND & ND & ND & 0.019 & ND & 0.006 & ND & ND & ND & ND & ND \\
\hline Mercury (total, mg/L) & ND & ND & ND & ND & ND & ND & ND & ND & ND & ND & ND & ND & ND \\
\hline Selenium (total, mg/L) & ND & ND & ND & ND & ND & ND & ND & ND & ND & ND & ND & ND & ND \\
\hline Silver (total, mg/L) & ND & ND & ND & ND & ND & ND & ND & ND & ND & ND & ND & ND & ND \\
\hline Iron (total, mg/L) & 27 & 31 & 37 & 3.5 & 35 & 8.7 & 17 & 3.7 & 1.5 & 4 & 2 & 2.4 & 58 \\
\hline Manganese (total, mg/L) & 1.5 & 1.2 & 1.6 & 0.34 & 2.3 & 1.7 & 0.28 & 0.084 & 0.78 & 0.35 & 0.94 & 0.32 & 2.2 \\
\hline Sodium (total, mg/L) & 7.6 & 5.7 & 13 & 8.7 & 7.7 & 130 & 24 & 39 & 100 & 54 & 22 & 37 & 13 \\
\hline Vanadium (total, mg/L) & ND & ND & ND & ND & ND & ND & ND & ND & ND & ND & ND & ND & ND \\
\hline Benzene (mg/L) & ND & ND & ND & ND & ND & ND & ND & ND & ND & ND & ND & ND & ND \\
\hline Toluene (mg/L) & ND & ND & ND & ND & ND & ND & ND & ND & ND & ND & ND & ND & ND \\
\hline Ethylbenzene (mg/L) & ND & ND & ND & ND & ND & ND & ND & ND & ND & ND & ND & ND & ND \\
\hline Total Xylenes (mg/L) & ND & ND & ND & ND & ND & ND & ND & ND & ND & ND & ND & ND & ND \\
\hline Total Organic Halides (mg/L) & ND & ND & ND & ND & ND & ND & ND & ND & ND & ND & ND & ND & 0.034 \\
\hline Chloride (mg/L) & 1 & 3 & 5 & 22 & 36 & 320 & 73 & 140 & 130 & 120 & 45 & 120 & 27 \\
\hline Sulfate (mg/L) & 22 & 23 & 42 & 28 & 10 & 56 & 42 & 30 & 45 & 52 & 60 & 42 & 45 \\
\hline Nitrate Nitrogen (mg/L) & 0.06 & 0.1 & 0.09 & ND & 0.09 & 1 & 0.07 & 0.61 & 0.74 & 0.51 & 0.23 & 0.39 & ND \\
\hline Fluoride (mg/L) & ND & ND & ND & 0.06 & ND & ND & ND & ND & 0.06 & 0.2 & 0.17 & 0.06 & ND \\
\hline Total Recoverable Phenolics (mg/L) & ND & ND & ND & ND & ND & ND & ND & ND & ND & ND & ND & ND & ND \\
\hline Cyanide (total. mg/L) & ND & ND & ND & ND & ND & ND & ND & ND & ND & ND & ND & ND & ND \\
\hline Total Organic Carbon (mg/L) & 2 & 2 & 3 & 1 & 2 & 2 & 2 & 1 & 1 & 4 & 2 & 2 & 2 \\
\hline Naphthalene (ug/L) & ND & ND & ND & ND & ND & ND & ND & ND & ND & ND & ND & ND & ND \\
\hline Other Semivolatiles & ND & ND & ND & ND & ND & ND & ND & ND & ND & ND & ND & ND & ND \\
\hline
\end{tabular}


TABLE 22

FETC-MGN

April 1998 Groundwater Data for "B-C Aquifer"

\begin{tabular}{|c|c|c|c|c|c|}
\hline \multirow[b]{2}{*}{ Parameter } & \multirow[b]{2}{*}{11} & \multirow[b]{2}{*}{ SP2-BC } & \multicolumn{2}{|c|}{ Sample Location } & \multirow[b]{2}{*}{ GAS-5 } \\
\hline & & & $32 \mathrm{~A}$ & 31 & \\
\hline $\mathrm{pH}(\mathrm{s} . \mathrm{u})$ & 6 & 6.81 & 5.59 & 5.45 & 6.29 \\
\hline Specific Conductance (uMhos) & 305 & 491 & 1223 & 837 & 984 \\
\hline Temperature (C) & 17.5 & 19 & 18.7 & 19 & 18.9 \\
\hline Arsenic (total, mg/L) & 0.005 & ND & ND & ND & 0.013 \\
\hline Barium (total, mg/L) & 0.25 & 0.05 & 0.042 & 0.12 & 0.16 \\
\hline Cadmium (total, mg/L) & ND & ND & 0.0015 & ND & ND \\
\hline Chromium (total, mg/L) & ND & ND & ND & ND & ND \\
\hline Lead (total, mg/L) & ND & ND & ND & ND & ND \\
\hline Mercury (total, mg/L) & ND & ND & ND & ND & ND \\
\hline Selenium (total, mg/L) & ND & ND & ND & ND & ND \\
\hline Silver (total, mg/L) & ND & ND & ND & ND & ND \\
\hline Iron (total, mg/L) & 32 & 1.3 & ND & 0.85 & 59 \\
\hline Manganese (total, mg/L) & 1.2 & 0.1 & 2.3 & 6.8 & 12 \\
\hline Sodium (total, mg/L) & 5.2 & 4 & 130 & 66 & 110 \\
\hline Vanadium (total, mg/L) & ND & ND & ND & ND & ND \\
\hline Benzene (mg/L) & ND & ND & ND & ND & ND \\
\hline Toluene $(\mathrm{mg} / \mathrm{L})$ & ND & ND & ND & ND & ND \\
\hline Ethylbenzene (mg/L) & ND & ND & ND & ND & ND \\
\hline Total Xylenes (mg/L) & ND & ND & ND & ND & ND \\
\hline Total Organic Halides (mg/L) & ND & ND & ND & ND & ND \\
\hline Chloride (mg/L) & 3 & 5 & 290 & 190 & 180 \\
\hline Sulfate (mg/L) & 26 & 26 & 110 & 55 & 120 \\
\hline Nitrate Nitrogen (mg/L) & ND & 0.06 & 0.71 & ND & ND \\
\hline Fluoride (mg/L) & 0.07 & 0.14 & 0.2 & 0.08 & 0.08 \\
\hline Total Recoverable Phenolics (mg/L) & ND & ND & ND & ND & ND \\
\hline Cyanide (total. mg/L) & ND & ND & ND & ND & ND \\
\hline Total Organic Carbon (mg/L) & 2 & 2 & 2 & 2 & 4 \\
\hline Naphthalene (ug/L) & ND & ND & 14 & ND & ND \\
\hline Other Semivolatiles & ND & ND & ND & ND & ND \\
\hline
\end{tabular}


TABLE 23

FETC-MGN

August 1998 Groundwater Data for "Morgantown Aquifer"

\begin{tabular}{|c|c|c|c|c|}
\hline \multirow[b]{2}{*}{ Parameter } & \multicolumn{3}{|c|}{ Sample Location } & \multirow[b]{2}{*}{ D4M } \\
\hline & D1M & D2M & D3M & \\
\hline $\mathrm{pH}(\mathrm{s} . \mathrm{u})$ & 7.2 & 8.85 & 7.09 & 9.01 \\
\hline Specific Conductance (uMhos) & 360 & 617 & 431 & 1241 \\
\hline Temperature (C) & 18.1 & 17.1 & 18.7 & 17.9 \\
\hline Arsenic (total, mg/L) & 0.01 & ND & ND & 0.006 \\
\hline Barium (total, mg/L) & 0.18 & 0.16 & 0.88 & 0.096 \\
\hline Cadmium (total, mg/L) & ND & ND & ND & ND \\
\hline Chromium (total, mg/L) & ND & ND & ND & ND \\
\hline Lead (total, mg/L) & ND & ND & ND & ND \\
\hline Mercury (total, mg/L) & ND & ND & ND & ND \\
\hline Selenium (total, $\mathrm{mg} / \mathrm{L}$ ) & ND & ND & ND & ND \\
\hline Silver (total, mg/L) & ND & ND & ND & ND \\
\hline Iron (total, $\mathrm{mg} / \mathrm{L}$ ) & 12 & 4.8 & 0.96 & 2.6 \\
\hline Manganese (total, mg/L) & 1.2 & 0.16 & 0.085 & 0.038 \\
\hline Sodium (total, mg/L) & 7.5 & 140 & 39 & 320 \\
\hline Vanadium (total, $\mathrm{mg} / \mathrm{L}$ ) & ND & ND & ND & ND \\
\hline Benzene (mg/L) & ND & ND & ND & ND \\
\hline Toluene (mg/L) & ND & ND & ND & ND \\
\hline Ethylbenzene (mg/L) & ND & ND & ND & ND \\
\hline Total Xylenes (mg/L) & ND & ND & ND & ND \\
\hline Total Organic Halides (mg/L) & ND & ND & ND & ND \\
\hline Chloride (mg/L) & 14 & 2 & 4 & 7 \\
\hline Sulfate $(\mathrm{mg} / \mathrm{L})$ & 41 & 7 & 20 & 36 \\
\hline Nitrate Nitrogen $(\mathrm{mg} / \mathrm{L})$ & ND & 0.26 & 0.1 & 0.11 \\
\hline Fluoride $(\mathrm{mg} / \mathrm{L})$ & 0.09 & 0.52 & 0.18 & 3.4 \\
\hline Total Recoverable Phenolics (mg/L) & ND & ND & ND & ND \\
\hline Cyanide (total. mg/L) & ND & ND & ND & ND \\
\hline Total Organic Carbon (mg/L) & 2 & 2 & 1 & 3 \\
\hline Naphthalene (ug/L) & ND & ND & ND & ND \\
\hline Other Semivolatiles & ND & ND & ND & ND \\
\hline
\end{tabular}


TABLE 24

FETC-MGN

August 1998 Groundwater Data for "A Aquifer"

\begin{tabular}{|c|c|c|c|c|c|c|c|c|c|c|c|c|c|}
\hline & & & & $\mathrm{Sa}$ & ple Loca & & & & & & & & \\
\hline Parameter & $\mathbf{A}$ & B & SP1A & SP4-A & SP8A & SP9A & I & $\mathbf{J}$ & $\mathbf{K}$ & $\mathbf{L}$ & $\mathbf{M}$ & $\mathbf{N}$ & GAS-4 \\
\hline $\mathrm{pH}(\mathrm{s} . \mathrm{u})$ & 6.2 & 5.7 & 6.71 & 7 & 5.71 & 6.7 & 6.53 & 5.57 & 5.16 & 5.19 & 5 & 5.09 & 6.54 \\
\hline Specific Conductance (uMhos) & 311 & 306 & 319 & 271 & 356 & 1218 & 456 & 664 & 1417 & 773 & 377 & 686 & 250 \\
\hline Temperature $(\mathrm{C})$ & 17.2 & 17.6 & 16.5 & 17.9 & 19.1 & 16.7 & 17.8 & 19.2 & 21.7 & 18.5 & 18.8 & 18.2 & 18.8 \\
\hline Arsenic (total, mg/L) & ND & 0.006 & ND & ND & ND & ND & 0.0006 & ND & ND & ND & ND & ND & 0.016 \\
\hline Barium (total, $\mathrm{mg} / \mathrm{L}$ ) & 0.37 & 0.25 & 0.15 & 0.043 & 0.32 & 0.28 & 0.39 & 0.49 & 0.2 & 0.077 & 0.041 & 0.18 & 0.26 \\
\hline Cadmium (total, mg/L) & ND & ND & 0.0013 & ND & ND & ND & ND & ND & 0.0012 & ND & ND & ND & 0.001 \\
\hline Chromium (total, $\mathrm{mg} / \mathrm{L}$ ) & ND & ND & ND & ND & ND & ND & ND & ND & ND & ND & ND & ND & ND \\
\hline Lead (total, mg/L) & ND & ND & ND & ND & ND & 0.007 & ND & ND & 0.014 & ND & ND & ND & 0.014 \\
\hline Mercury (total, mg/L) & ND & ND & ND & ND & ND & ND & ND & ND & ND & ND & ND & ND & ND \\
\hline Selenium (total, mg/L) & ND & ND & ND & ND & ND & ND & ND & ND & ND & ND & ND & ND & ND \\
\hline Silver (total, mg/L) & ND & ND & ND & ND & ND & ND & ND & ND & ND & ND & ND & ND & ND \\
\hline Iron (total, mg/L) & 24 & 33 & 38 & 2.2 & 38 & 15 & 18 & 1.7 & 4.7 & 1.1 & 2.4 & 1.5 & 93 \\
\hline Manganese (total, $\mathrm{mg} / \mathrm{L}$ ) & 1.3 & 1.2 & 1.7 & 0.61 & 2.5 & 1.9 & 0.33 & 0.11 & 2.4 & 0.61 & 1 & 0.33 & 2.3 \\
\hline Sodium (total, mg/L) & 7.6 & 5.1 & 14 & 7.4 & 7.9 & 120 & 27 & 47 & 150 & 87 & 24 & 44 & 9.4 \\
\hline Vanadium (total, $\mathrm{mg} / \mathrm{L}$ ) & ND & ND & ND & ND & ND & ND & ND & ND & ND & ND & ND & ND & ND \\
\hline Benzene (mg/L) & ND & ND & ND & ND & ND & ND & ND & ND & ND & ND & ND & ND & ND \\
\hline Toluene (mg/L) & ND & ND & ND & ND & ND & ND & ND & ND & ND & ND & ND & ND & ND \\
\hline Ethylbenzene (mg/L) & ND & ND & ND & ND & ND & ND & ND & ND & ND & ND & ND & ND & ND \\
\hline Total Xylenes (mg/L) & ND & ND & ND & ND & ND & ND & ND & ND & ND & ND & ND & ND & ND \\
\hline Total Organic Halides (mg/L) & ND & ND & ND & ND & ND & ND & ND & ND & ND & ND & ND & ND & ND \\
\hline Chloride (mg/L) & 1 & 3 & 4 & 25 & 39 & 280 & 88 & 150 & 360 & 180 & 49 & 150 & 26 \\
\hline Sulfate (mg/L) & 27 & 24 & 59 & 29 & 12 & 79 & 62 & 43 & 79 & 93 & 79 & 55 & 47 \\
\hline Nitrate Nitrogen (mg/L) & ND & ND & ND & ND & ND & 0.8 & ND & 0.58 & 1 & 0.33 & 0.13 & 0.52 & ND \\
\hline Fluoride (mg/L) & 0.09 & 0.08 & 0.06 & 0.11 & 0.08 & 0.06 & 0.07 & ND & 0.52 & 0.23 & 0.18 & 0.09 & 0.06 \\
\hline Total Recoverable Phenolics (mg/L) & ND & ND & ND & ND & ND & ND & ND & ND & ND & ND & ND & ND & ND \\
\hline Cyanide (total. mg/L) & ND & ND & ND & ND & ND & ND & ND & ND & ND & ND & ND & ND & ND \\
\hline Total Organic Carbon (mg/L) & 1 & 2 & 2 & 1 & 2 & 2 & 2 & 1 & 2 & 3 & 2 & 2 & 3 \\
\hline Naphthalene (ug/L) & ND & ND & ND & ND & ND & ND & ND & ND & ND & ND & ND & ND & ND \\
\hline Other Semivolatiles & ND & ND & ND & ND & ND & ND & ND & ND & ND & ND & ND & ND & ND \\
\hline
\end{tabular}


TABLE 25

FETC-MGN

August 1998 Groundwater Data for "B-C Aquifer"

\begin{tabular}{|c|c|c|c|c|c|}
\hline & & \multicolumn{3}{|c|}{ Sample Location } & \multirow[b]{2}{*}{ GAS-5 } \\
\hline Parameter & 11 & SP2-BC & $32 \mathrm{~A}$ & 31 & \\
\hline $\mathrm{pH}(\mathrm{s} . \mathrm{u})$ & 6 & 6.81 & 5.59 & 5.45 & 6.29 \\
\hline Specific Conductance (uMhos) & 305 & 491 & 1223 & 837 & 984 \\
\hline Temperature $(\mathrm{C})$ & 17.5 & 19 & 18.7 & 19 & 18.9 \\
\hline Arsenic (total, mg/L) & 0.005 & ND & ND & ND & 0.013 \\
\hline Barium (total, mg/L) & 0.25 & 0.05 & 0.042 & 0.12 & 0.16 \\
\hline Cadmium (total, mg/L) & ND & ND & 0.0015 & ND & ND \\
\hline Chromium (total, $\mathrm{mg} / \mathrm{L}$ ) & ND & ND & ND & ND & ND \\
\hline Lead (total, mg/L) & ND & ND & ND & ND & ND \\
\hline Mercury (total, mg/L) & ND & ND & ND & ND & ND \\
\hline Selenium (total, $\mathrm{mg} / \mathrm{L}$ ) & ND & ND & ND & ND & ND \\
\hline Silver (total, $\mathrm{mg} / \mathrm{L}$ ) & ND & ND & ND & ND & ND \\
\hline Iron (total, mg/L) & 32 & 1.3 & ND & 0.85 & 59 \\
\hline Manganese (total, $\mathrm{mg} / \mathrm{L}$ ) & 1.2 & 0.1 & 2.3 & 6.8 & 12 \\
\hline Sodium (total, mg/L) & 5.2 & 4 & 130 & 66 & 110 \\
\hline Vanadium (total, $\mathrm{mg} / \mathrm{L}$ ) & ND & ND & ND & ND & ND \\
\hline Benzene (mg/L) & ND & ND & ND & ND & ND \\
\hline Toluene (mg/L) & ND & ND & ND & ND & ND \\
\hline Ethylbenzene (mg/L) & ND & ND & ND & ND & ND \\
\hline Total Xylenes (mg/L) & ND & ND & ND & ND & ND \\
\hline Total Organic Halides (mg/L) & ND & ND & ND & ND & ND \\
\hline Chloride (mg/L) & 3 & 5 & 290 & 190 & 180 \\
\hline Sulfate $(\mathrm{mg} / \mathrm{L})$ & 26 & 26 & 110 & 55 & 120 \\
\hline Nitrate Nitrogen (mg/L) & ND & 0.06 & 0.71 & ND & ND \\
\hline Fluoride (mg/L) & 0.07 & 0.14 & 0.2 & 0.08 & 0.08 \\
\hline Total Recoverable Phenolics (mg/L) & ND & ND & ND & ND & ND \\
\hline Cyanide (total. mg/L) & ND & ND & ND & ND & ND \\
\hline Total Organic Carbon (mg/L) & 2 & 2 & 2 & 2 & 4 \\
\hline Naphthalene (ug/L) & ND & ND & 14 & ND & ND \\
\hline Other Semivolatiles & ND & ND & ND & ND & ND \\
\hline
\end{tabular}

